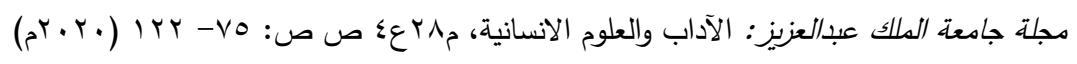
DOI:10.4197/Art.28-4.3

\title{
مدى اعتماد الجمهور السعودي على مواقع التواصل الاجتماعي في المعرفة بضضايا المجتمع: دراسة مسحية في مدينة الرياض
}

\author{
د. عبدالملك بن عبدالعزيز الثلهوب \\ الأستاذ المشارك بقسم الإعلام -كلية الآداب \\ بجامعة الملك سعود
}

مستخلص. هدفت هذه الدراسة إلى التعرف على الدوافع والأهداف التي تدفع الجمهور السعودي للاعتماد على

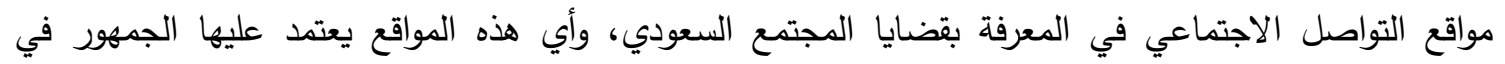

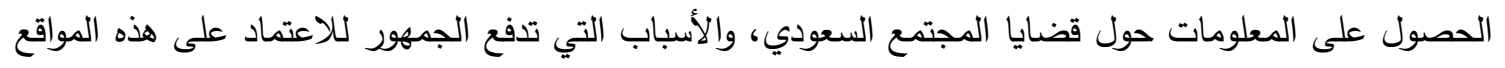

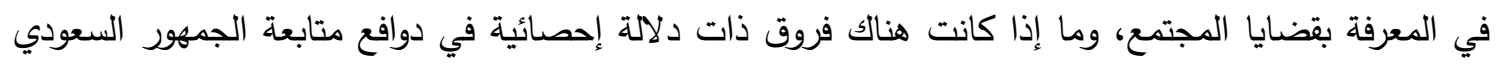

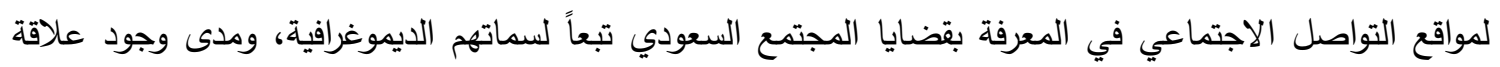

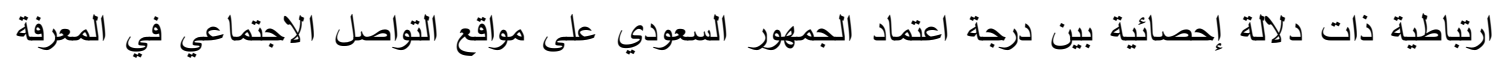

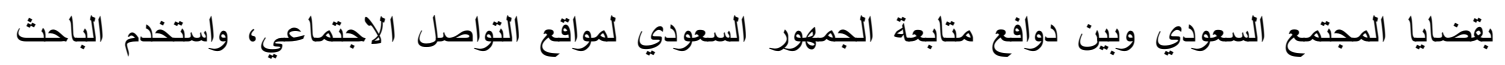

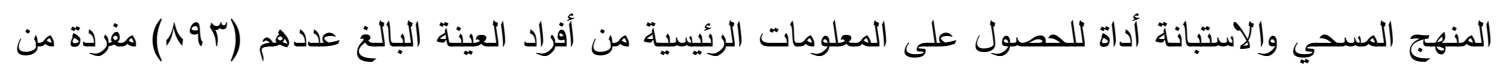

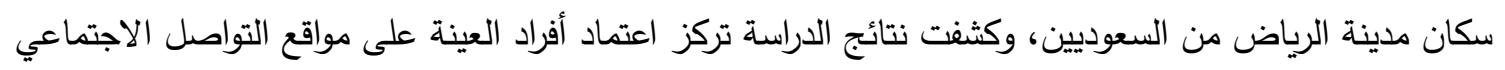

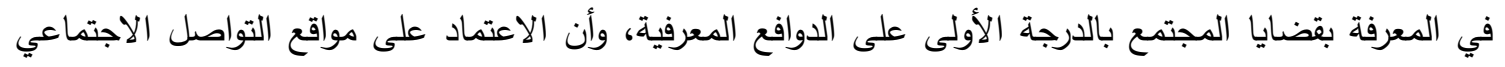

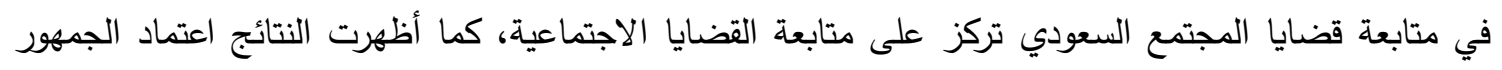

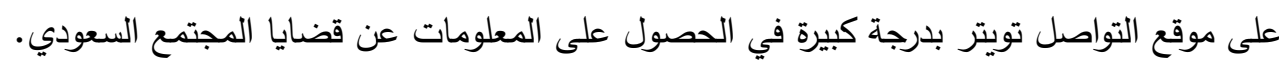

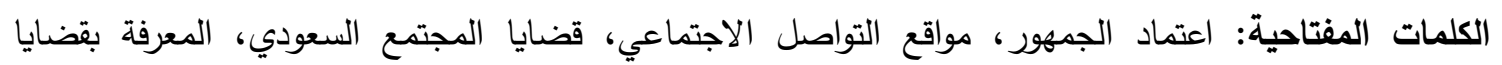
المجتمع، الجمهور السعودي

هاتين الوسيلتين الطريق لنظام إعلامسي جديد يقوم المقدمة

على اسـاس العولمـة الإعلاميـة التـي تعـد امتـداداً شـهـ الإعـلام في العقدين الأخيرين تطورات كبيـرة

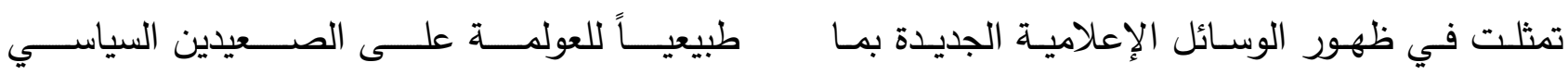

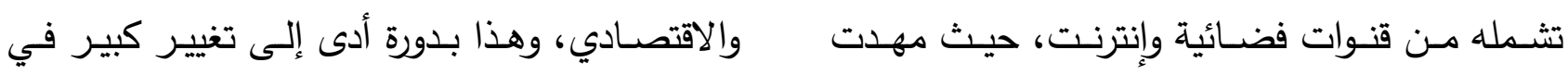


سواء من حيث التعليم أو الأبحاث أو التجارة والتسويق أو الصحافة والإعلام أو فيما يتعلق بالترابط الاجتماعي والعلاقات بين الناس من خلال

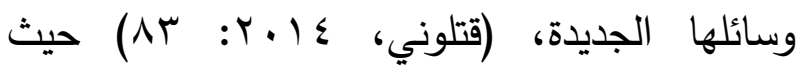
مهدت الطريق لكافة المجتمعات للتقارب والتعارف وتبادل الآراء والأفكار، واستفاد كل متصفح لهذه الشبكة من الوسائط المتعددة المتاحة فيها، وأصبحت أفضل وسيلة لتحقيق التواصل بين الأفراد والجماعات، فالإنترنت كوسيلة اتصال تعد المظهر الأكثر تجلياً لتكنولوجيا الإعلام والاتصال، وأخرجت الجماهير والأفراد العاديين من دورهم السلبي إلى دور أكثر فعالية من خلال توليد فضاءات إبداعية واتصالية خاصة بهم، فالمواقع الإلكترونية ومواقع التواصل الاجتماعي، غيرت مضمون وشكل الإعلام الحديث، وخلقت نوعاً من التواصل بين أصحابها ومستخدميها من جهة، وبين المستخدمين أنفسهم من جهة أخرى، لقد أدى هذ كله إلى تحويل المتلقي إلى مرسل ومصدر للمادة الإعلامية، وأضحت مساحات اتصالية يعبر فيها المغمورون عن آرائهم وما يختلج في صدورهم، وأن تكون الأداة التي استطاعت أن توحد وتقرب بين أقطار العالم. (شفيق، با ـr

وهكذا نرى أن أهم ما يميز وسائل الإعلام الحديثة بشكل عام ومواقع التواصل الاجتماعي إتاحتها المجال للناس للمشاركة والتعبير عن اهتماماتهم واحتياجاتهم ومطالبهم بصورة لم تكن متاحة لهم من
الثــكل العــام للمشـــد الإعلامــي وطــرق تلقــي المعلومات ووسائلها حتى أصبح الإنسان مثل النجم الذي يسبح في فضـاء تحيط بـه المعلومـات من كل اتجـاه، وأصسبحت هذه الوسـائل تلاحق الإنسـان في كل مكان وتقدم لله ما يحتاجـه من أخبار ومعلومات، وأدى ذلــك بالتــالي إلــى " تغييـر مفهـوم الإعــلام وطبيعتـهـ في هـذا العصـر حيـث لـم يعـد مرتبطـاً بمخرجـات وسـائل الاتصـال الجمـاهيري بـل أصـبح شــديد الالتصــاق بالمعلومــات: الماليــة، والعلميــة،

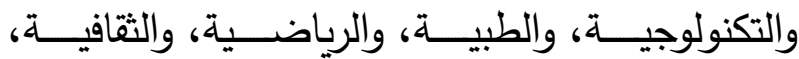
والاجتماعيـة، بمعنى أن الإعـلام لم يعد حكراً على

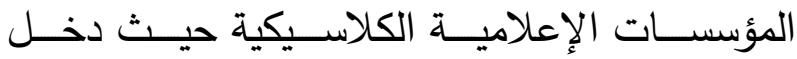
متعـاملون جدد في مجال إنتاج الإعـلام، وتخزينـه، وتوزيعـه، لـم تكـن لهـم علاقـة سـابقة بوسـائل الإعـلام الكلاسيكية، وهذا مـا جعل القيمة التبادلية للإعلام تسعى لتطغسى على قيمتــه الاسـتخدامية في ظل تحـول البنيـة الاقتصادية للمؤسسة المنتجة للإعلام والقائمة على الطلب وليس على العرض، أي خلافاً للمنطق الذي كان يستند إليــه اقتصـاد وسـائل الإعـلام في منتصـف القـرن

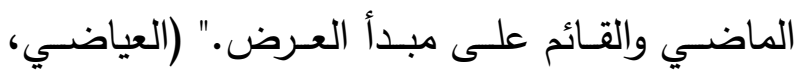
http://www.siironline.org/alabwab/solta5(18)/0 (15.htm لقد أدى انتشار شبكة الإنترنت والذي بلغ عدد

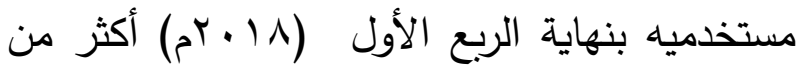
أربعة مليار مستخدم، (https://taqnia24.com) إلى (ألى ربط أجزاء هذا العالم، ولعبت دوراً بارزاً في تطوير كل القطاعات التي دخلت عليها وفي الارتقاء بها 
والحرية، إضافة إلى قدرة مستخدمي هذه المواقع على نشر أي قضية أو موضوع سواء أكان سياسي أو إو هده

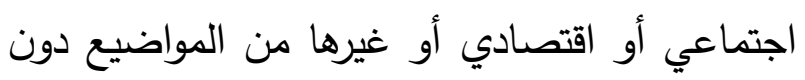
الاضطرار للتعامل مع حراس البوابة في الإعلام

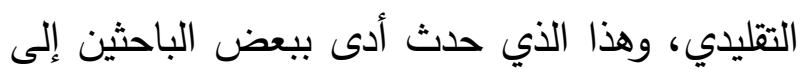

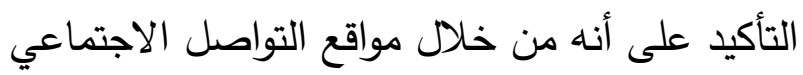
مثل تويتر والفيسبوك واليوتيوب يمكن للجمهور أن أن

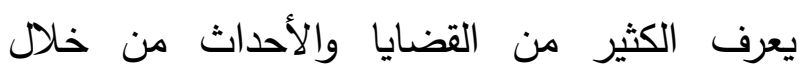
الثهود المباشرين الذين شاهدوا ورأوا تلك الأحداث، كما يمكن أن يتخاطب هذا الجمهور مع الشهود المباشرين ويتاقش معهم بدلاً من خيار الإعلام التقليدي الذي يُنقل عبر مندوب أو مراسل ولا يمكن من لئن للجمهور أن يتفاعل مباشرة مع تلك الأحداث مناث والقضايا ومع تلك الوقائع ومع الثهود عليها. (القرني، 11) إن مواقع التواصل الاجتماعي والتي يبلغ عدد التي

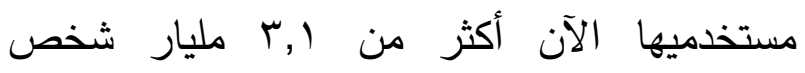

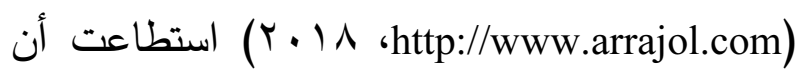
تفرض نفسها بقوة على الجمهور في العالم وفي المملكة العربية السعودية بشكل خاص، حيث يشهر هذا العصر نزوحاً من قبل الأفراد على اختلاف

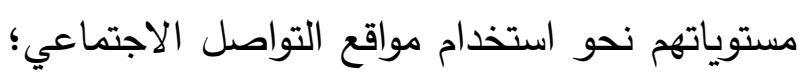

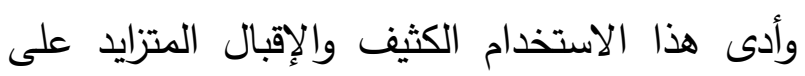
هذه المواقع إلى انتاج الأخبار والمعلومات وتحليلها وتوزيعها على جماهير مترابطة تكنولوجياً ولا تحدها حدود جغرافية، وأضحى ملايين الأفراد يلجؤون إلى وتى
قبل، لهذا فنحن أمام إعلام جديد اختلفت فيه مؤسساته وأدواته وأساليبه وأهدافه ومالكيه.

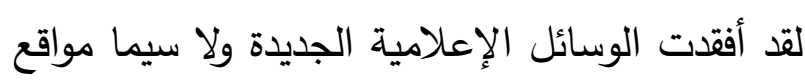
التواصل الاجتماعي الإعلام التقليدي بريقه وقللت من أهميته ودفعت كثير من الناس إلى تهميشها بعد الإعلى

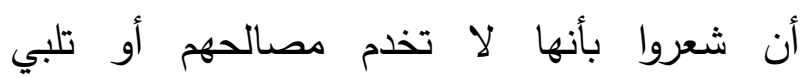

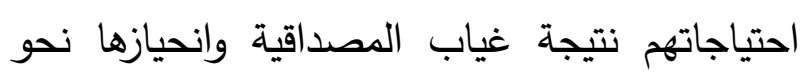
السلطة والمال والنفوذ، حيث استطاع الإعلام الجديد وخاصة مواقع التواصل الاجتماعي من كسر احتكار

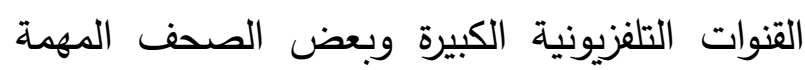
والمؤثرة بعد أن كانت هذه القنوات وتلك الصحف تسهم في تكوين الرأي العام باعتبار أنها أهم وأول

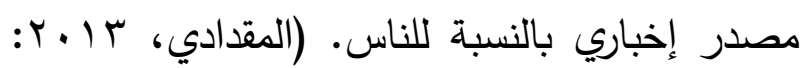
$(191$ لقد باتت مواقع التواصل الاجتماعي اليوم النافذة

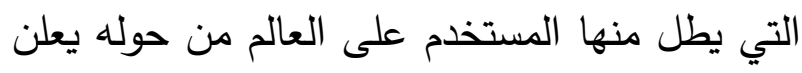
فيها عن نفسه، ويجد من يعلن عن نفسه مثله ويشاركه الرأي، والسرعة في تغطيتها للأحداث، وأنها أحد البدائل والخيارات المطروحة أمام الجمهور

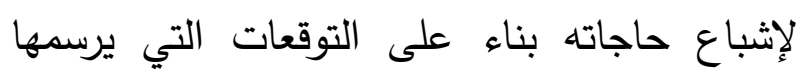

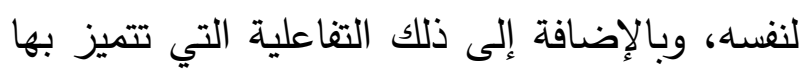

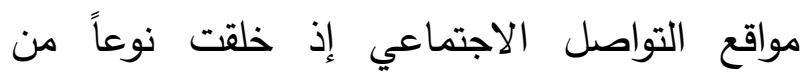
التفاعل ولاسيما بين الشباب والعالم بعد العزلة التي لتواهي كانت تفرضها عليه ظروف الحياة، وأنها تعتبر المتتفس للمستخدمين ليعبروا عن اهتماماتهم وهموهم المتنوعة بعد حالة الكبت والعيب ومصادرة الرأي 
ع-سعي هذه الدراسة إلى تحديد حجم ونوعية الدوافع التي تدفع الجمهور للاعتماد على مواقع التواصل

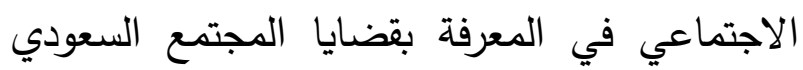
سواء أكانت دوافع معرفية أم توجيهية أم سلوكية.

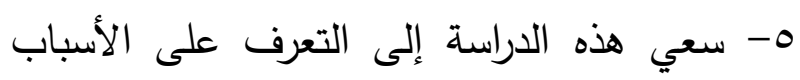

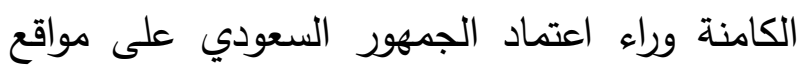
التواصل الاجتماعي في المعرفة بقضايا المجتمع السعودي.

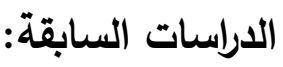

قام الباحث بمراجعة الدراسات السابقة المتعلقة بموضوع دراسته، وقد وجد عدداً من الدراسات ذات الصلة بموضوع هذه الدراسة، ومن هذه الدراسات

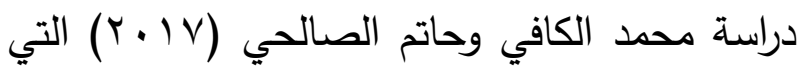
استهدفت الكثف عن دور شبكات التواصل الاجتماعي في إدداد الثباب العربي بالأخبار والمعلومات حول ظاهرة الإرهاب من خلال معرفة

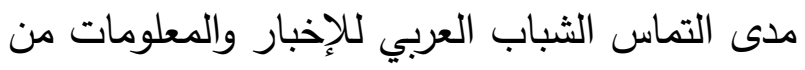
شبكات التواصل الاجتماعي و واعتمادهم عليها كمصدر للمعلومات حول ظاهرة الإرهاب، واستخدم الباحث المنهج المسحي، والاستبانة أداة لجمع بيانات الرهاب، ولثنات

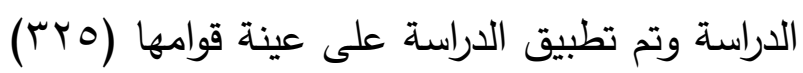
مغردة من الشباب العربي في كل من الأردن والسعودية واليمن ومصر ، وبينت نتائج الدراسة أن هن الن الثباب يلتمس من شبكات التواصل الاجتماعي المعلومات المتعلقة بالحوادث والعمليات الإرهابية التي تحصل في بلدانهم، وأن التأثيرات المعرفية
مواقع التواصل الاجتماعي لجذب الانتباه إلى القضايا المهمة والجدلية التي تم تهميشها أو تغييبها،

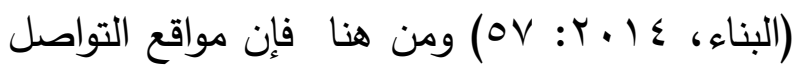
الاجتماعي اليوم أصبحت وسيلة فعالة في التأثير في كثير من القضايا حيث نجحت هذه المواقع في التي تسليط الضوء بكثافة على قضايا مسكوت عنها في وسائل الإعلام التقليدية مما يجعل هذه القضايا

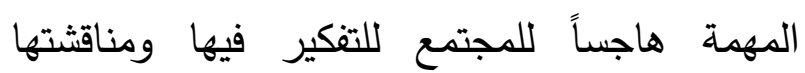

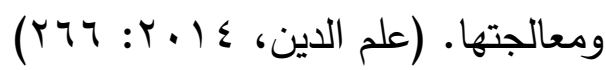

\section{أهمية الدراسة - مانة}

تكمن أهمية الدراسة من خلال الآتي: ا-يشهد المجتمع السعودي تحولات اقتصادية

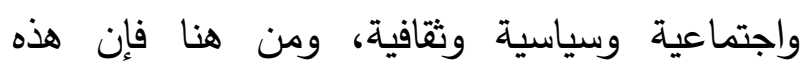

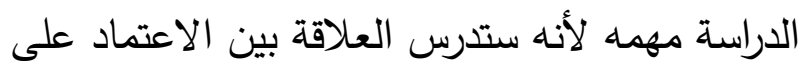

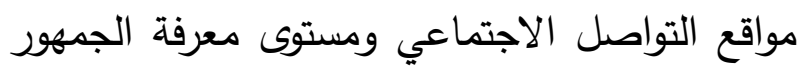
السعودي بقضاياه المختلفة. r- أهمية دراسة الجمهور في مثل هذه الفترات التي يشها فيها المجتمع السعودي إصلاحات اجتماعية واقتصادية واضحة باعتبارهم الطرف المستهدف لفاهف والمستقيد من عمليات الإصلاح لمعرفة آرائهم وتصوراتهم بما يفيد في النهاية صناع السياسات والقرارات في خططهم وبرامجهم. ب-استحواذ مواقع التواصل الاجتماعي على اهتمام فئات كبيرة من المجتمع السعودي، وبالتالي فإنه من

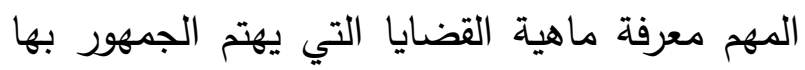
والأهداف الناتجة عن هذا الاعتماد. 


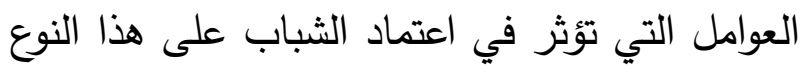

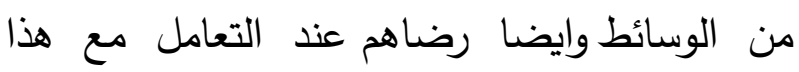

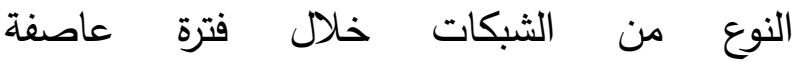
الحزم. واستخذم الباحث الطريقة الوصفية التحليلية والاستبيان لتغطيه الجزء التطبيقي من الدراسة والذي تم عملها لأغراض الدراسة وفقا للخطوات العلمية

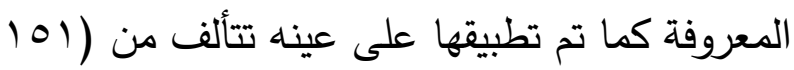
مصطلح) التي يستخدمها الثباب السعوديين، وبينت نتائج الدراسة أن وسائل التواصل الاجتماعي تحتل التصابل المرتبة الاولي في مصادر المعلومات التي يعتمد عليها الثباب السعودي في معرفة الامور المتعلقة بعملية عاصفة الحزم، ومن حيث رضاهم عن دور وسائل التواصل الاجتماعي فان استخدام مثل هذه

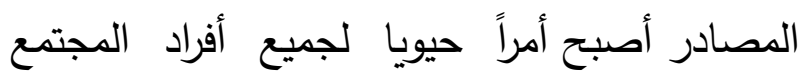
السعودية. وتطرقت دراسة منية إبراهيم (17 + (Y) إلى التعرف على اعتماد الشباب الجامعي المصري على مواقع إلى

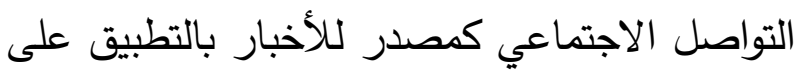
موقعي الفيسبوك وتويتر ، واستخدمت الباحثة لدراستها المنهج المسحي واستخدمت في إطاره الاستبيان أداة لجمع بيانات الدراسة الميدانية، وبينت نتائج الدراسة الطانية

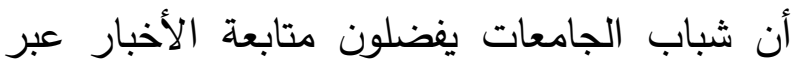

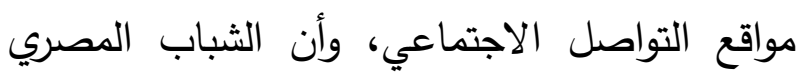

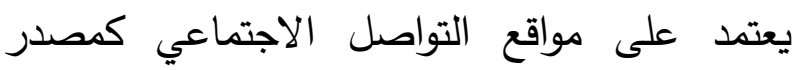
أساسي للأخبار وذلك لسرعتها في تغطية الأحداث، وتناولها لقضايا هامة في المجتمع المصري بحرية، لكان،
جاءت في مقدمة التأثيرات الناتجة عن اعتماد الثباب على شبكات التواصل الاجتماعي كمصدر للمعلومات حول ظاهرة الإرهاب.

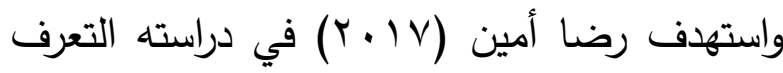
على مدى اعتماد الجمهور البحريني على الإعلام الجديد كمصدر للمعلومات عن قضايا التتمية الإعلادية المستدامة، وتأثيرات هذا الاعتماد على معارف الجمهور واتجاهاتهم وسلوكياتهم فيما له صلة بتلك الاتكات

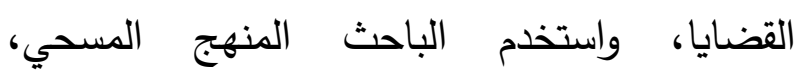
والاستبانة أداة لجمع بيانات الدراسة وتم تطبيق النائ

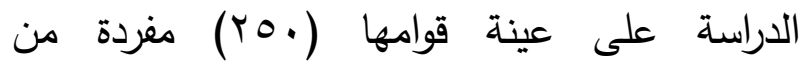

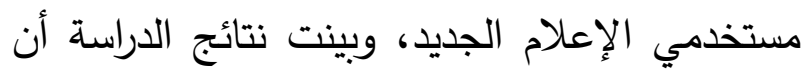
غالبية المبحوثين يرون أن الإعلام الجديد يقدم معلومات محدودة عن قضايا التتمية المستدامة، وأن شبكات التواصل الاجتماعي التي يستخدمونها وتتناول قضايا التتمية المستدامة تويتر ثم سناب شات فالانستجرام ثم الفيسبوك، وأن تويتر يتصدر توريت شبكات التواصل الاجتماعي في الاستخدام لاى لإى

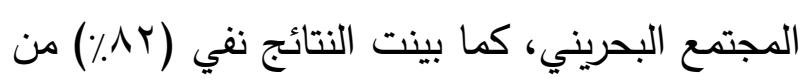
المبحوثين أن تكون مواقع التواصل ذات إسهام في الإثراء الثقافي بقضايا التتمية الدستدامة. وسعى عامر الدهمشي (Amer Aldahmashi 2015) إلى التعرف على مدى اعتماد الثباب السعودي علي وسائل التواصل الاجتماعي كمصدر للمعلومات حول العملية العسكرية المعروفة باسم عاصفة الحزم. اضافة الي ذلك تسعي هذه الدراسة لفهم 
المنهج المسحي، والاستبانة أداة لجمع بيانات

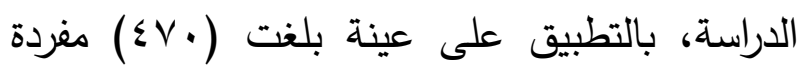
من طلبة الجامعات الأردنية، وبينت نتائج الدراسة بأنة اقتصار مواقع التواصل الاجتماعي التي يستخدمها أفراد العينة على الفيسبوك وتويتر واليوتيوب، وأن مساهمة مواقع التواصل الاجتماعي في تزويد الطلبة بالأخبار والمعلومات جاء في المرتبة الأولى.

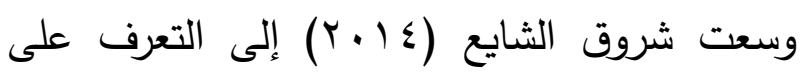
دور شبكة تويتر في تنمية مشاركة الثباب السعودي

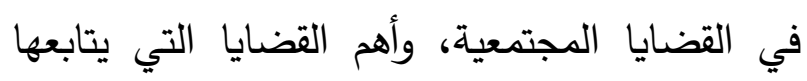
الثباب عبر تويتر، واستخدمت الباحثة المنهج

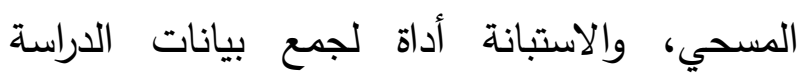

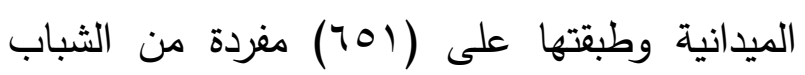
السعودي، وبينت نتائج الدراسة أن غالبية أفراد العينة لديهم اهتمام بالقضايا الاجتماعية، وأن النسبة الأكبر من العينة تشارك في هاشتاق السعودية وأن أبرز مشاركات الشباب في الهاشتاق في إطار القضايا المجتمعية من خلال التغريد حول القضايا وإعادة التغريد، وأن السرعة في نقل الأحداث ومتابعة الأخبار وتفاصيلها جاءت في مقدمة أسباب متابعة

الثباب السعودي للقضايا المجتمعية عبر تويتر .

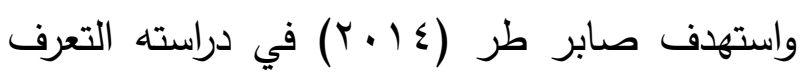
على العلاقة بين الاعتماد على المواقع الإخبارية الإليكترونية ومستوى معرفة الشباب اليمني بالقضايا السياسية اليمنية والعربية، واستخدم الباحث لدراسته

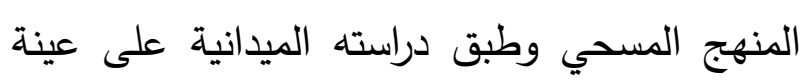

كما بينت نتائج الدراسة أن المبحوثين يفضلون

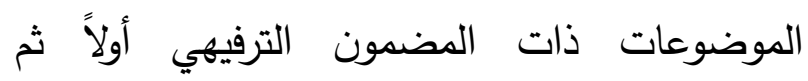
المضمون الثقافي ثانياً ، فالمضمون الرياضي ثالثاً، ثم المضمون الفني.

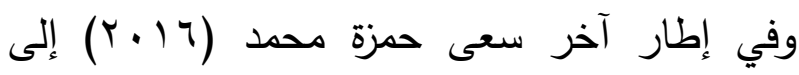
التعرف على مدى اعتماد ابناء الجالية المصرية إلى الدية بدولة الامارات العربية المتحدة على وسائل الإعلام التقليدية والحديثة كمصدر للمعلومات أثناء أزمة جزيرتي تيران وصنافير ، واستخدم الباحث لدراسته المنهج المسحي، والاستبانة أداة لجمع بيانات الدراسة ولتئ الميدانية، وطبقها على عينة عمدية قوامها (· (Y) مفردة من المصريين المقيمين في الإمارات، وبينت

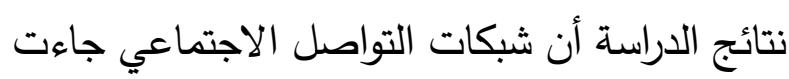
في مقدمة المصادر التي يعتمد عليها المبحوثين في الحصول على المعلومات حول قضية جزيرتي تيران وصنافير ، وأن من أهم أسباب اختيار أفراد العينة لوسيلة إعلامية معينة للحصول على معلومات حول اهن قضية الجزيرتين هو السرعة في نقل الخبر وتغطية

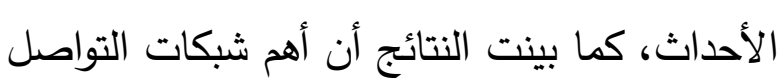

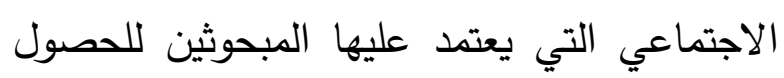
على المعلومات أثناء قضية الجزيرتين، الفيسبوك عاعئي بالدرجة الأولى ثم تويتر في المرتبة الثانية. وفي ذات الإطار استهدف شرحبيل أبو سليم

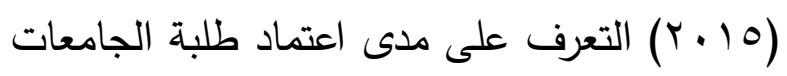
الأردنية على شبكات التواصل الاجتماعي للحصول على الأخبار والمعلومات، واستخدم الباحث لدراسته 
كمصدر للمعلومات الصحية ما يزال في المستوى

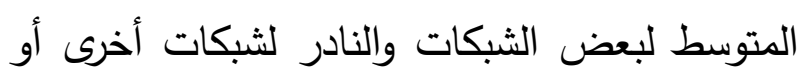

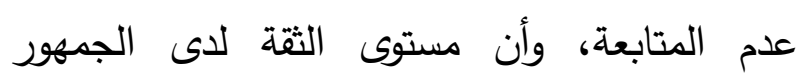

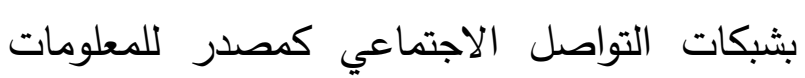
الصحية ما يزال متدنياً. التعليق على الاراسات السابقة: ماندان

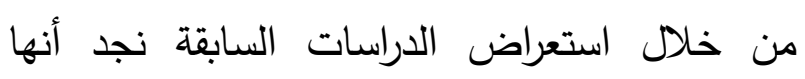

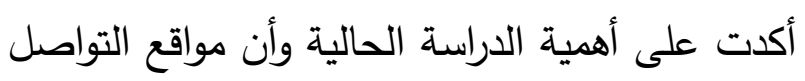
الاجتماعي في ظل تتامي أعداد مستخدميها تمثل

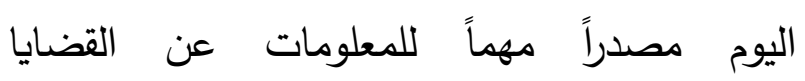
والمشكلات الغائبة والمساحة الأوسع لتعددية الرأي بما يلغي فرص الهيمنة ويبطل خيارات العزل

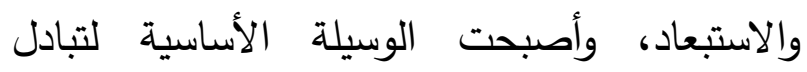

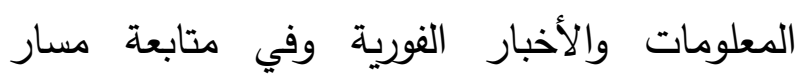
وتطورات الأحداث، وعموماً فمن خلال استعراض وفي الاض

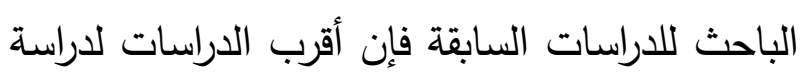
الباحث دراسة الثايع إلا أنها ركزت على دراست التهات موقع واحد من مواقع التواصل الاجتماعي وهو تويتر ودوره في تتمية مشاركة الثباب في القضايا

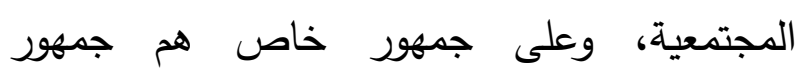
الشباب، في حين أن دراسة الباحث لا تتناول الأدوار

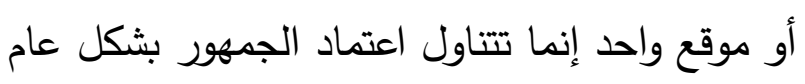
على مواقع التواصل الاجتماعي في المعرفة بقضايا المجتمع السعودي ككل، أما الدراسات الأخرى فنجد الأند أن أغلبها ركز على دراسة قضايا محددة في مواقع التواصل الاجتماعي كدراسة الكافي والصالحي التي دراي
قوامها (09٪) مفردة من الشباب اليمني في مدينة صنعاء، والدراسة التحليلية على (YV) موقع إخباري إليكتروني يمني وعربي، واستخدم لجمع بيانات الدراسة الميدانية الاستبانة، وأداة تحليل المضموني ولئي للدراسة التحليلية، وبينت نتائج الدراسة حضور القضايا السياسية اليمنية والعربية لدى نوعي المواقع التابعة لصحف ورقية أهلية ونوع المواقع المستقلة،

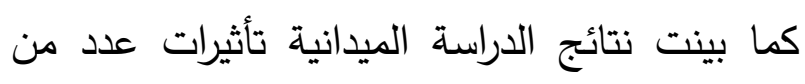

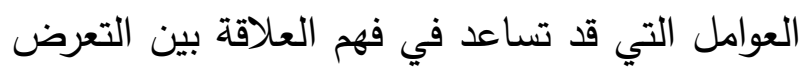

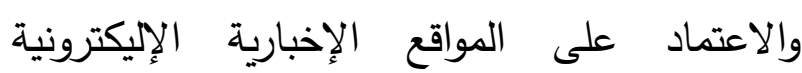
ومستوى المعرفة بالقضايا السياسية اليمنية والعربية

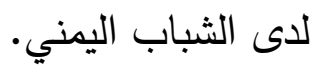

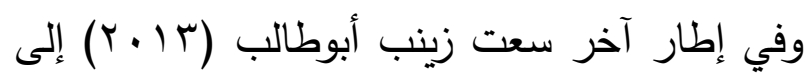

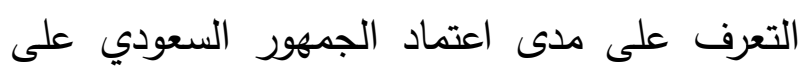

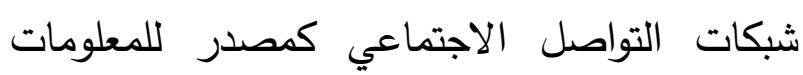
الصحية مقارنة بالمصادر الأخرى، والتأثيرات

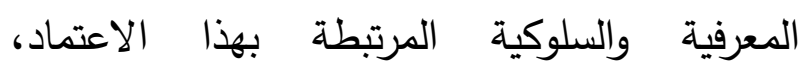

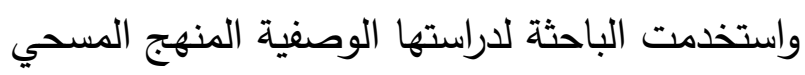

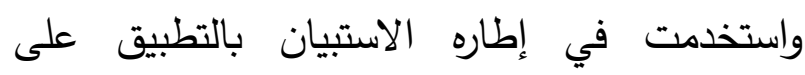
(Y99) مفردة من سكان مدينة الرياض، وبينت نتائج الدراسة أن الأطباء والصيادلة ما زالوا أهم مصدر وبند

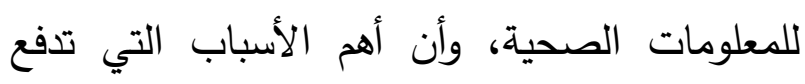
الجمهور للاعتماد على مصادر محددة في الحصول على المعلومات الصحية هي مساعدتهم في اتخاذ قرارات معينة في الجانب الصحي، وأن مستوى

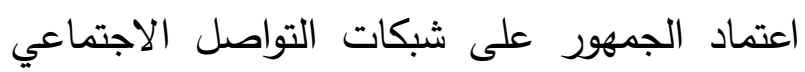


قدمته هذه الدراسات من تراكم معرفي ساعد الباحث كثيراً في تحديد وصياغة الإطار المرجعي للدراسة وفي بناء منهجيتها وصياغة تساؤلاتها وبناء استمارة الدراسة وفي تفسير نتائجها ومقارنتها بالدراسات

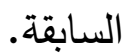

\section{الإطار المرجعي للدراسة:}

تستند هذه الدراسة في إطارها النظري على نظرية الاعتماد على وسائل الإعلام، وتهتم هذه النظرية برصد ودراسة التأثيرات المختلفة لوسائل الإعلام

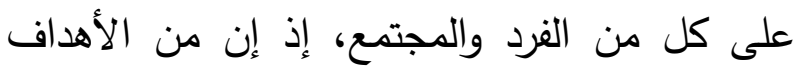

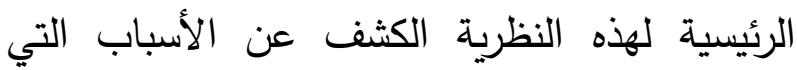
تجعل لوسائل الإعلام على اختلافها آثار قوية مباشرة، وفي أحيان أخرى تكون لها تأثيرات غير لإعلات

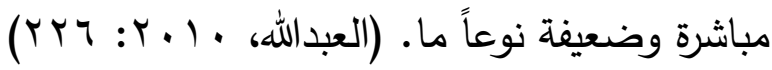
ويمكن القول وفقاً لمكاوي والسيد إلى "إن نظرية الاعتماد على وسائل الإعلام هي نظرية بيئية،

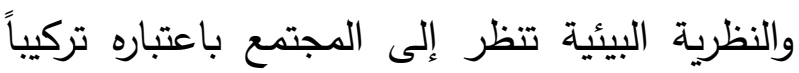

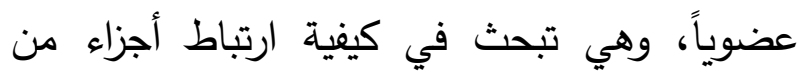
النظم الاجتماعية صغيرة وكبيرة يرتبط كل منهما

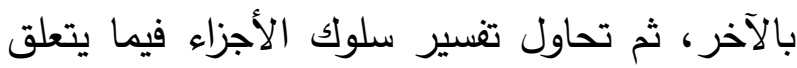
بهذه العلاقات، والمفترض أن يكون نظام وسائل

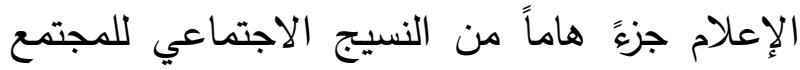

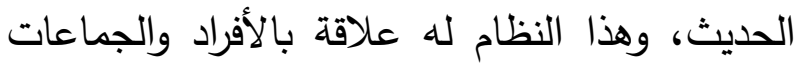
والمنظمات والنظم الاجتماعية الأخرى، وقد تتسم هذه العلاقات بالتعاون أو بالصراع، وقد تكون ديناميكية متغيرة أو ساكنة ثابتة، وقد تكون مباشرة
تتاولت دور مواقع التواصل كمصدر للمعلومات عن

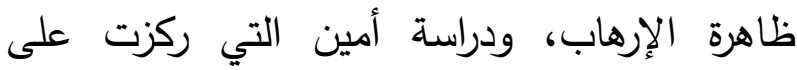
قضايا التتمية المستدامة في البحرين، ودراسة أبوطالب التي تتاولت القضايا الصحية، ودراسة طر التي ركزت على المعرفة بالقضايا السياسية في المواقع الإخبارية الإليكترونية، ودراسة السميح التي لتي

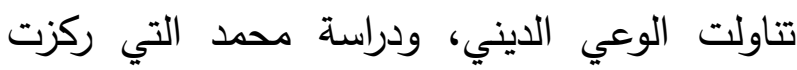
على المصادر التي يعتمد عليها المصريين في ولي الإمارات العربية المتحدة في الحصول على تلى المعلومات عن جزيرتي تيران وصنافير، في حين أن الدراسة الحالية تتناول مختلف القضايا، كما اهتمت لتين بعض الدراسات بمعرفة مدى الاعتماد على مواقع التواصل الاجتماعي في الحصول على الأخبار وماهي المواقع التي يحرص أفراد العينة على متابعة الأخبار من خلالها كدراسة منية وأبو سليم وهذا لهانيا جانب مختلف عن دراسة الباحث كما أن بيئة هذه الدراسات مختلفة عن دراسة الباحث. وعلى ضوء ما سبق فإن الدراسات السابقة تُظهر أهمية الدراسة الحالية، وأن هذه الدراسة التي تتناول اعتماد الجمهور السعودي على مواقع التواصل الاجتماعي في المعرفة بقضايا المجتمع جديدة من

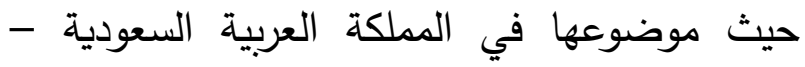
حسب اطلاع الباحث-، إذ إن العديد من الدراسات

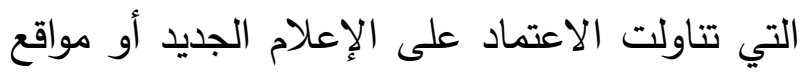

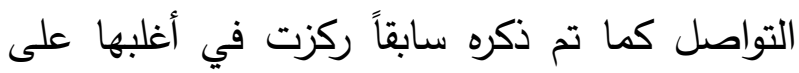

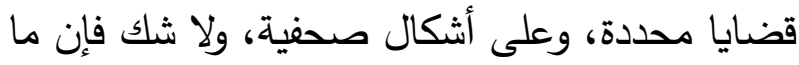


المصادر في التالي: (ديفلير، ورويكتش، و99 1: $(\leqslant) 0$ 6 $\leqslant) \leqslant$

1- جمع المعلومات: ويعني أن الصحفيون يجمعون المعلومات التي نحتاج إلى معرفتها، وكتاب السنياريو يقدمون معلومات عن أحداث حقيقية أو خيالية تتيح لنا إشباع هدف اللعب أو المرح مع

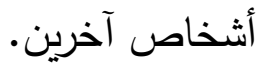
r- تتسيق المعلومات حيث يتم تحويل وتتقيح المعلومات التي تم جمعها أو خلقها ووضعها في سياق مناسب في شكل قصة صحفية أو فيلم سينمائي أو برنامج إذاعي أو تلفزيوني. r- نشر المعلومات وتوزيعها بصورة جماهيرية كبيرة وذلك لخدمة أهداف المؤسسة. ووفقاً لما سبق تشير العبد إلى أن فكرة نظرية الاعتماد الأساسية تتلخص في أن أفراد الجمهور يعتمدون على المعلومات التي توفرها وسائل الإعلام لتحقيق مجموعة من الأهداف والدوافع من أهمها: الحصول على المعلومات حول موضوع معين، والترفيه والتعلم، والاقتناع وتبني مفهوم أو سلوك ما، وتقويم سلوك معين بهدف الوقاية من الوقوع في خطأ ما، وتوجيه العمل في إطار من التوقعات وأخلاقيات

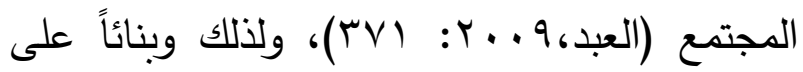
ما ذكر أنفاً فإن اعتماد أفراد الجمهور على وسائل الإعلام يتنوع لتحقيق ثلاثة أهداف هامة هي: 1- الفهم: ويتمثل في الفهم الذاتي من خلال تعلم المرو عن ذاته ونموه كشخص، والحصول على
وقوية أو غير مباشرة وضعيفة." (مكاوي و السيد، (ए) $\varepsilon:$ : $9 \wedge \wedge$ وقد سجلت الورقة المقدمة بعنوان مفهوم المعلومات لساندرا بول روكيتش عام 9 ام الفكرة الأساسية لنشأة نظرية الاعمتاد على وسائل الإعلام حيث دعت إلى التحول من المفهوم المرتكز على الإقناع في وسائل الإعلام إلى النظر لها كنظام معلومات يشتق قوته من خلال علاقات اعتماد متبادلة بين الأفراد، الجماعات، النظم، المنظمات،وبين مصادر المعلومات لدى وسائل الإعلام التي تقوم بدورها في

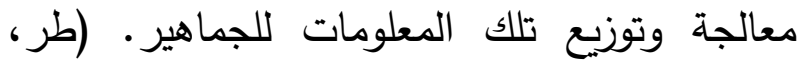
$(7 \leq: Y \cdot) \leq$ الركائز التي تقوم عليها نظريـة الاعتماد ومن خلال ما سبق فإن علاقة الاعتماد على وسائل الإعلام تقوم على ركيزيتين رئيسيتين هما: (مكاوي،

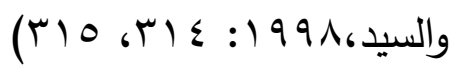
أولاً: الأهداف: فحتى يحقق أفراد الجمهور والمنظمات المختلفة أهدافهم الشخصية والاجتماعية فإن عليهم أن يعتمدوا على موارد يسيطر عليها أشخاص أو جماعات أو منظمات أخرى. ثانياً: المصادر حيث يسعى الأفراد والمنظمات إلى المصادر المختلفة التي تحقق أهدافهم، إذ تعد وسائل الإعلام نظام معلومات تسيطر على ثلاثة أنواع من مصادر المعلومات يجب على الأفراد الحصول عليها من أجل تحقيق أهدافهم التي يأملونها، وتتلخص هذه 
الأمر بشبكات داخلية من الأصدقاء والأسرة، وكذلك بنظم تربوية ودينية وسياسية وغيرها تساعد الناس

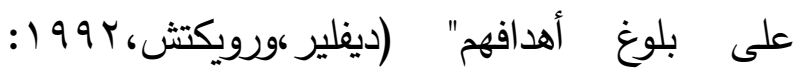
. ( $\leqslant$ r. وعطفاً على ما سبق فإن قوة وسائل الإعلام كما ذكرنا سابقاً تكمن في سيطرتها على مصادر معلومات معينة تلزم الأفراد لبلوغ أهدافهم الشخصية،

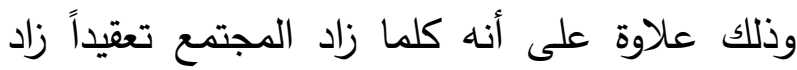
اتساع مجال الأهداف الشخصية التي تتطلب

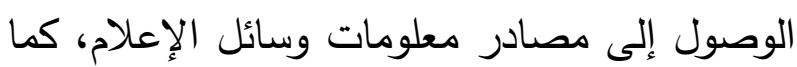
إن الواقع الحالي يشير إلى أن الناس مدفعون لفهم

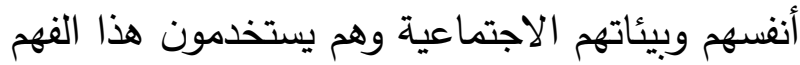

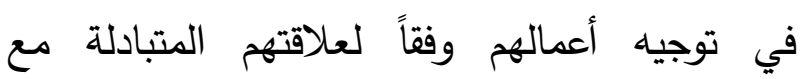
الأخرين، إذ يمثل الفهم والتوجيه والتسلية الأبعاد الثثلاثة الكبيرة لدوافع الإنسان التي تحدد سلوك الأفراد تجاه وسائل الإعلام، وتعتبر مهمة وضرورية حتى لإنى تؤدي إلى علاقات اعتماد رئيسية ومتثابهة (مكاوي،

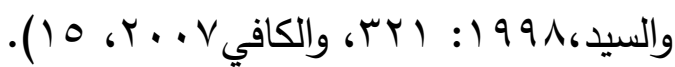
تأثيرات الاعتماد على وسائل الإعلام: تتحدد الأثار الناتجة على اعتماد أفراد الجمهور على لالى لاعلى وسائل الإعلام كما رصدها ملفين ديفلير وساندرا بول روكيتش في ثلاثة تأثيرات على النحو التالي: 1- التأثيرات المعرفية: والتي تتمثل في تجاوز مشكلة الغوض الناتجة عن نقص المعلومات التي يتعرض لها الفرد أو نقص المعلومات أو عدم كفايتها لفهم معاني الأحداث أو تحديد التفسيرات الصحيحة
الخبرات ومعرفة أشياء عن البيئة المحيطة به وتفسيراتها، والفهم الاجتماعي من خلال معرفة أشياء عن العالم أو الجماعة المحلية وتفسيرها (ثروت، .$(\leqslant 9 \cdot 64 \cdot .7$ ץ- التوجيه: ويشتمل على ثلاثة أمور، الأول توجيه ذاتي مثل اتخاذ القرارات المناسبة، والثاني توجيه العمل والسلوك مثل أن تقرر ماذا تشتري، وكيف تلبس، وكيف تحتفظ بصحتلك، أما التوجيه الثالث فهو توجيه تفاعلي تبادلي مثل الحصول على دلالات عن كيفية التعامل أو التصرف مع المواقف الجديدة

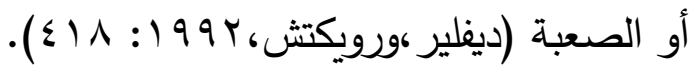
ץ- التسلية والترفيه: وتشتمل على التسلية المنعزلة مثل الراحة والاسترخاء عندما يكون الفرد بمفردة، والتسلية الاجتماعية كالذهاب إلى السينما أو مشاهدة التلفزيون أو الاستماع إلى الموسيقى مع الأسرة أو الو الهى

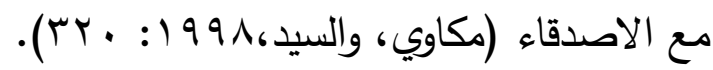
والأهداف السابقة الذكر لا يمكن تحقيقها بسهولة بدون وصول أفراد الجمهور إلى معلومات وسائل الإعلام، فهذه الوسائل تسيطر على مصادر معلومات معينة لكنها مرتفعة القيمة، وهي التي لإعلماني يحتاجها الأفراد لبلوغ وتحقيق أهداف فهرهم وتوجيهـم وتسليتهم، ومع ذلك يرى (ديلفير) و (روكيتش) عدم "المبالغة في أهمية وسائل الإعلام الجماهيري فهي تجعل بالفعل تحقيق الفهم والتوجيه وأهداف التسلية أكثر سهولة، ولكنها ليست الوسيلة الوحيدة لبلوغ هذه الأهداف، فالأفراد يتصلون بنهاية 
خلال المصادر الثخصية مع مراعاة وفرة المعلومات

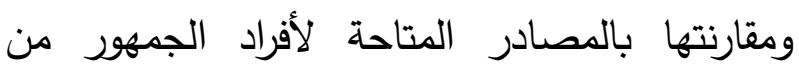

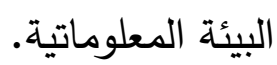
r- أن الشخص الأكثر اعتماداً على وسائل الإعلام لاشباع احتياجاته عبر استخدامها هو الأكثر اهتماماً

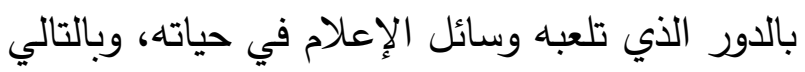
هو الأكثر تأثراً بهذه الوسائل فهنالك علاقة مباشرة

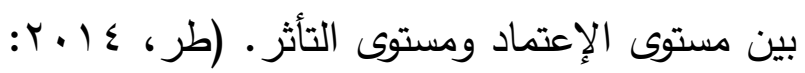

r- يعتبر النظام الإعلامي مهماً للمجتمع وتزداد

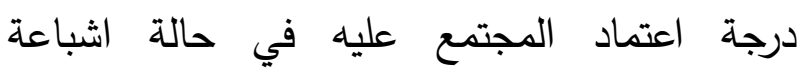

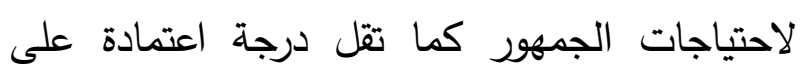
النظام الإعلامي في حالة وجود قنوات بديلة للحصول على المعلومات، حيث يختلف أفراد الجمهور في درجة اعتمادهم على وسائل الإعلام نتيجة اختلافهم في الأهداف والمصالح والحاجات الغردية.

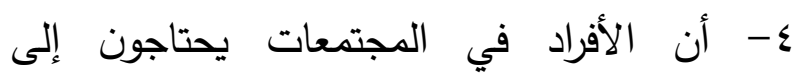
المعلومات لكي يستطيعوا اتخاذ عدة قرارات يومية

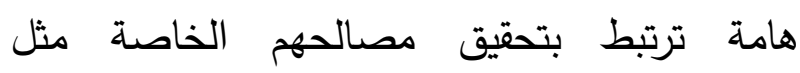

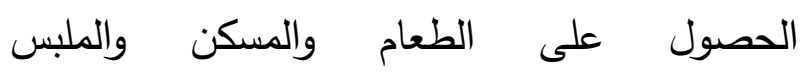
والمواصلات.

ه- تؤثر طبيعة الاختلاف بين شرائح أفراد الجمهور على الاختلاف في درجة الاعتماد على وسائل الإعلام؛ إذ إن درجة اعتماد الجمهور على وسائل الإعلام تختلف من شخص لآخر لاختلاف الأفراد
لها، كما تثمل التأثيرات المعرفية تكوين الاتجاهات

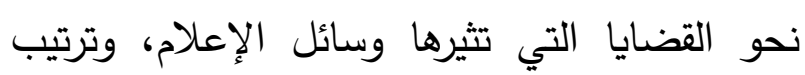
أولويات القضايا المطروحة في وسائل الإعلام وفقاً

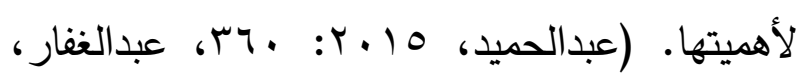
$(\wedge: r \cdot . q$ ץ- الأثار الوجدانية: وهي التي تشير للفئات

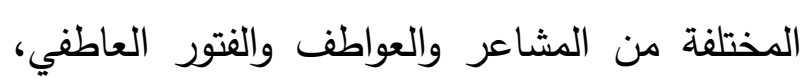
والمكونات الإنسانية من الحب والكره والإحساس ولفي بالخوف والقلق، ويظهر هذا التأثير عندما تقدم معلومات معينة من خلال الرسائل الإعلامية تؤثر ولثر على مشاعر الأفراد واستجاباتهم بالتالي في الاتجاه

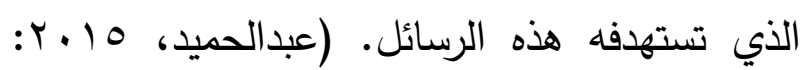
(rTt

r- الأثار السلوكية: وتتمثل في قيام الأفراد بسلوكيات إيجابية تعكس قناعاتهم بما تقدمه وسائل الإعلام، أو على العكس من ذلك فقد يتمثل التأثير الإعلامي في إحداث نوع من الخمول لإى الأفراد،

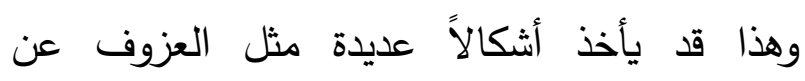

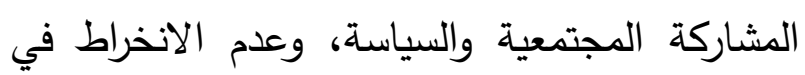

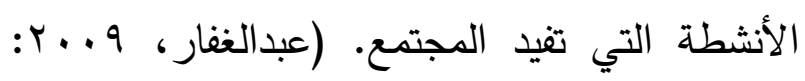

فروض نظرية الاعتماد على وسائل الإعلام:

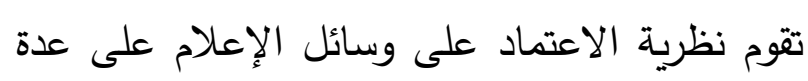
افتراضات وهي: 1- أن الاعتماد على وسائل الإعلام يزداد بزيادة

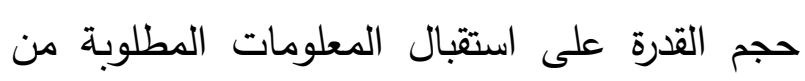




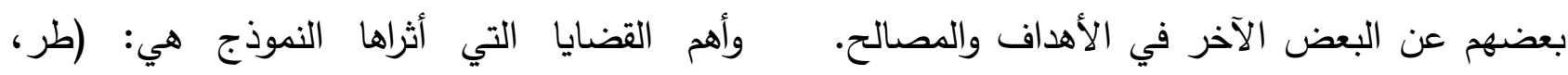
$\left(\mathrm{VO}: \mathrm{r}^{\prime}\right) \varepsilon$

.(Melvin, Sandra, 1992: 262-264)

1- اشتمل النموذج على عدة عوامل تؤثر في عملية نظرية الاعتماد والإعلام الجديد: الاعتماد على الإنترنت وتتمثل في الإحساس بالكفاءة يرى محمد عبدالحميد أن تفسير كل من ميلفين الذاتية والتي تعني ثقة الفرد بقدرته الذاتية في ديلفير وروكيتش لاعتماد الجمهور على وسائل

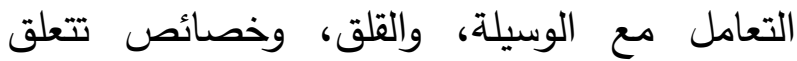

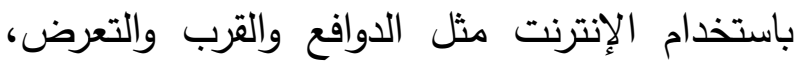
وهذا النموذج يساعد في تفسير العلاقة بين هذه المفاهيم وكيف تتؤث في عملية الاعتماد على

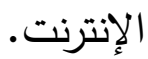
r- من القضايا المهمة التي استكثفها النموذج

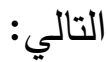
أ- تأثير عامل الإحساس بالكفاءة الذاتية والقلق كعوامل سابقة تؤثر في استخدام الإنترنت، ثم دور المفاهيم الأخرى كعوامل وسيطة وهي دوافع استخدام

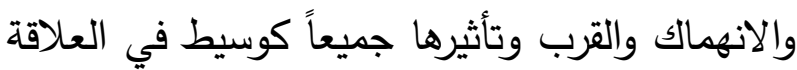
بين العوامل السابقة (الكفاءة والقلق) من جهة، والاعتماد على الإنترنت من جهة أخرى. r- تم اختبار نموذج مسار الاستخدام والاعتماد على الإنترنت حيث أشارت النتائج إلى أن مفاهيم الدوافع والاستغراق والقرب هي عوامل وسيطة مرتبطة بتأثير مفاهيم الكفاءة الذاتية والقلق في هرب ولي الاعتماد على الإنترنت، وأن الدوافع هي أهم عامل للتتبوء بمستوى الاعتماد على الإنترنت،وأنها أيضاً ممكن تتنبأ بمستوى الاستخدام العادي للإنترنت لاعى الإنس الفرد، فلأفراد الذين يستخدمون الإنترنت للبحث عن

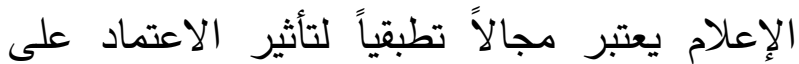
وسائل الاتصال الرقمي حيث أنهم يفتروضون قيام علاقة الاعتماد على دعامتين رئيسيتين تتمثلان في حاجة الجمهور إلى المعلومات التي تلبي حاجاته وتحقيق أهدافة، إذ تعتبر الأهداف المعرفية التي يسعى الفرد إلى تحقيقها ويعتمد فيها على وسائل الإعلام تعتبر كلها وظائف الاتصال الرقمي ويحققها نظام المعلومات الذي يتميز به هذا الاتصال، ونجدها موجودة بوفرة على المواقع العديدة لشبكة الإنترنت في حزم المواقع التي تم تصنيفها والتي يتمكن المستخدم أو الزائر من الوصول إليها لئيا واستخدامها ومنها مواقع التواصل الاجتماعي، فعلى قدر أهمية هذه الحاجات وقدرة حزم المواقع المختلفة على تتظيمها وتقديمها في مواقع شبكات الإنترنت بشكل عام ومواقع التواصل الاجتماعي بشكل خاص

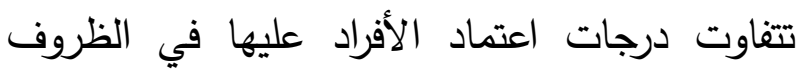

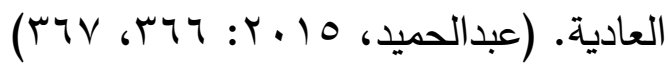
وقد قدمت بعض الدراسات ومنها دراسة (صن ؟ . . ب) نموذجاً للاعتماد على الإنترنت، ومن أبرز العوامل المؤثرة في عملية الاعتماد على الإنترنت 
r- يحاول هذا الاطار النظري فهم العلاقة المتبادلة بين الجمهور والإعلام والإجابة على سؤال ما هي الإطاي الأهداف والدوافع التي يتابع من أجلها الجمهور مواقع التواصل الاجتماعي هل هي بهدف الفهم أم الم التوجيه أم للتسلية والترفيه.

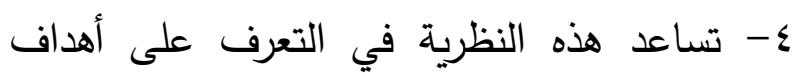
ودوافع المبحوثين في الاعتماد على مواقع التواصل في التعرف على القضايا المجتمع السعودي سواء

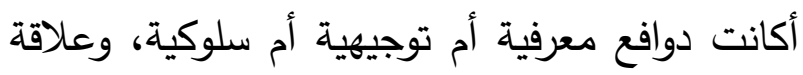
هذه الدوافع بحجم ودرجة اعتمادهم على تلك المواقع للحصول منها على المعلومات عن محتلف قضايا

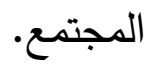

وعلى ضوء ما سبق فإن الباحث سيسعى من خلال

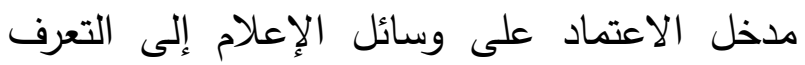
على ودوافع المبحوثين في الاعتماد على مواقع الاعلى إلى التواصل في التعرف على القضايا المجتمع السعودي سواء أكانت دوافع معرفية أم توجيهية أم سلوكية. مشكلة الدراسة:

تشهد مواقع التواصل الاجتماعي نمواً كبيراً، وباتت

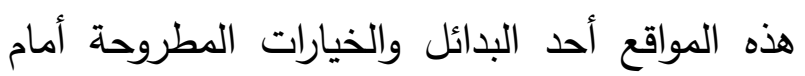

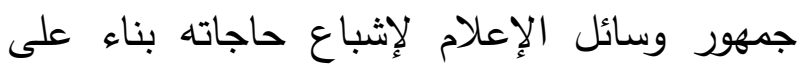

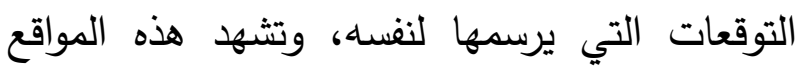
استخداماً كبيراً من قبل الجمهور في العالم ولدى لئى أفراد المجتمع السعودي بشكل خاص، حيث هيث يصل عدد مستخدمي مواقع التواصل في العالم أكثر من لئن ثلاثة مليار شخص، وعدد المستخدمين السعوديين
المعلومات هم أكثر ميلاً لتصفح المواقع على الثبكة، والذين يستخدمون الإنترنت لسهولتها والتحكم هم أكثر ميلاً لاستخدام البريد الإليكتروني.

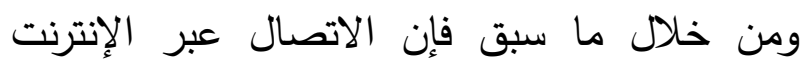

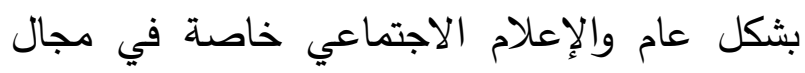
نظرية الاعتماد على وسائل الإعلام لا يعتبر نظاماً للمعلومات فقط ولكناه عديد من النظم الخاصة بفئات المستخدمين والزائرين وحزم المواقع ومحتواها وأهدافها التي تتفق مع أهداف وحاجات هؤلاء المستخدمين والزائرين، كما أن تأثيرات الاعتماد على الإنترنت

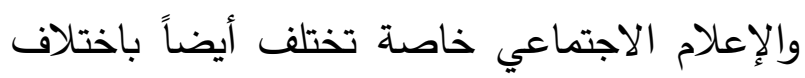
درجات الاعتماد على هذا الاتصال. (عبدالحميد،

(r79: $r$. 10

مدى ملائمة استخدام نظرية الاعتماد على وسائل الإعلام في هذه الدراسة: وانطلاقاً مما سبق فإن مدخل الاعتماد الإدهاد على وسائل الإعلام في هذه الدراسة يعد من المداخل المناسبة والملائمة للدراسة الحالية للإسباب التالية: 1- أن هذه النظرية تساعد في اختبار مدى اعتماد

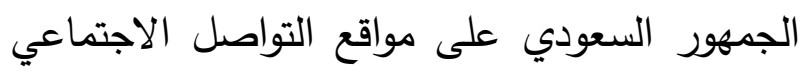
كمصدر من مصادر المعلومات عن محتلف قضايا

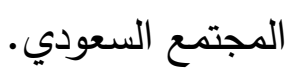
r- يساعد هذا الاطار النظري في الإجابة على

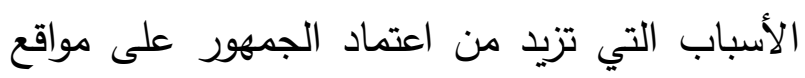
التواصل الاجتماعي. 
0-التعرف على نوعية القضايا التي يحرص الجمهور السعودي على متابعتها في مواقع التواصل الاجتماعي. تساؤلات الدراسة: ا-ما الوسائل الإعلامية التي يعتمد عليها الجمهور السعودي في الحصول على المعلومات عن قضايا البمجمج ץ-ما المواقع الإليكترونية التي يعتمد عليها الجمهور السعودي في المعرفة بقضايا المجتمع؟ الإلئ

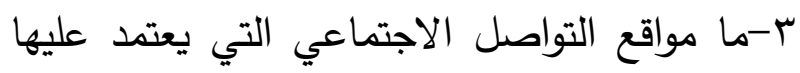

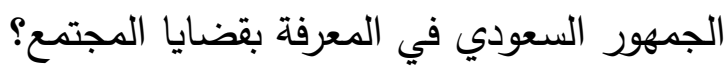
ع-ما نوعية القضايا التي يحرص الجمهور السعودي على متابعتها في مواقع التواصل الاجتماعي؟ ه-ما درجة اعتماد الجمهور السعودي على مواقع

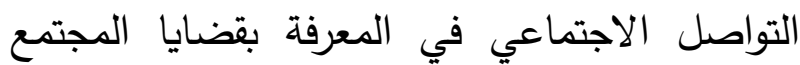
السعودي؟ צ-ما أسباب اعتماد الجمهور السعودي على مواقع

التواصل الاجتماعي في المعرفة بقضايا المجتم؟

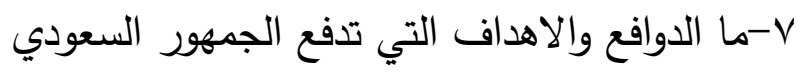
في الاعتماد على مواقع التواصل الاجتماعي في

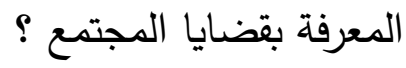

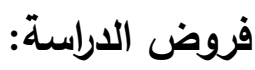
تسعى هذه الدراسة إلى اختبار الفروض الآتية:

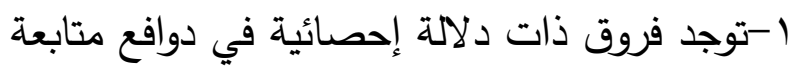

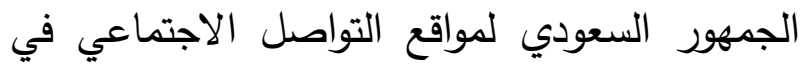

وفق تقرير وزارة الاتصالات وتقنية المعلومات أكثر من ثمانية عشر مليون مستخدم، فقد اتاحت هذه وله لهاته المواقع لأفراد المجتمع السعودي الاتصال والتواصل

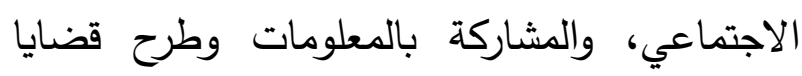
وموضوعات ما كانت تطرح في الوسائل الإعلامية ولية التقليدية، ولذلك فإن واقع استخدام مواقع التواصل الاجتماعي في المجتمع السعودي يفرض التحقق من

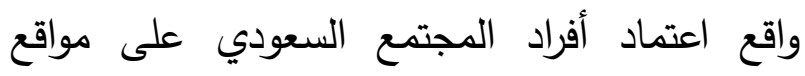
التواصل الاجتماعي في معرفتهم بقضايا المجتمع المختلفة ومن هنا فإن مشكلة هذه الدراسة تتحدد في

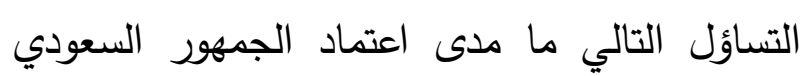
على مواقع التواصل الاجتماعي في المعرفة بقضايا

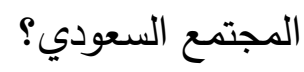
أهداف الدراسة:

تسعى هذه الدراسة إلى تحقيق الأهداف التالية:

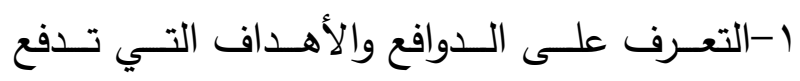
الجمهـور السـعودي للاعتمـاد على مواقـع التواصـل الاجتماعي في المعرفة بقضايا المجتمع السعودي.

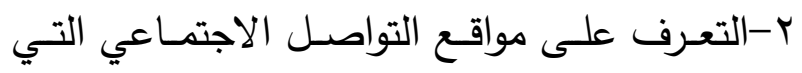
يعتمد عليها الجمهور في الحصول على المعلومات حول قضايا المجتمع السعودي. ب-معرفة درجة اعتماد الجمهور على مواقع التواصل في معرفة قضايا المجتمع السعودي. ع-التعرف على الأسباب التي تدفع الجمهور

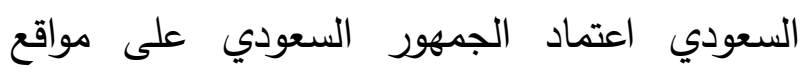
التواصل الاجتماعي في المعرفة بقضايا المجتمع. 
التعريفات الإجرائية لمصطلحات الاراسة: ا-الاعتماد على مواقع التواصل الاجتماعي: وتعني

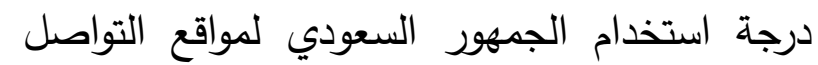

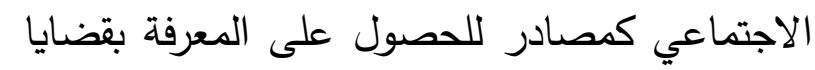
المجتمع المختلفة، ويتم قياسها في هذه الدراسة من عند

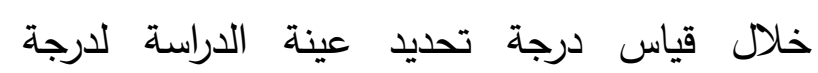
اعتمادهم على مواقع التواصل الاجتماعي. r- الجمهور السعودي ويقصد بهم في هذه الدراسة المواطنين السعوديين في المملكة العربية السعودية والقاطنين في مدينة الرياض من الذكور والإناث.

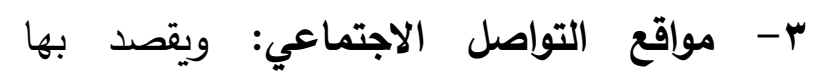
الشبكات الاجتماعية التفاعلية على شبكة الإنترنت

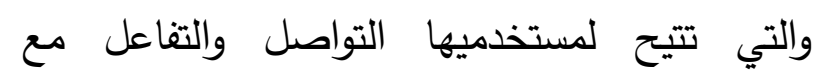

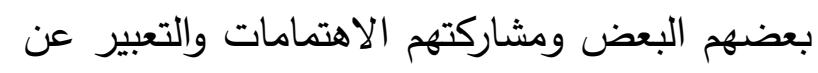

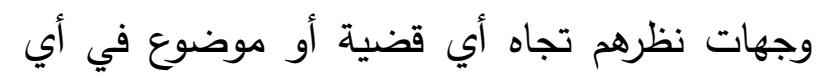
وقت يشاءون وفي أي مكان من العالم والمتمثلة في الفيسبوك وتويتر والواتسب وجوجل بلس واليوتيوب

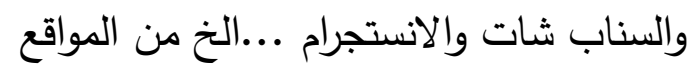
ع - المعرفة بقضايا المجتمع: وتعني الإدراك

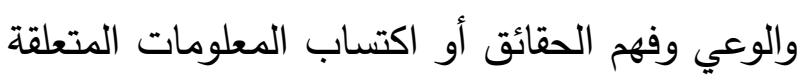

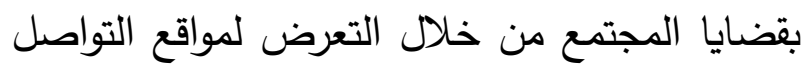

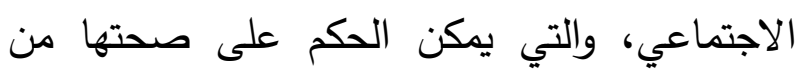
خلال المقاييس العلمية، وقد تم قياسها في هذه الدراسة بدرجة الاعتمادية على مواقع التواصل الاجتماعي ونوعية القضايا وأسباب الاعتماد وعدم لاعتم لاعتية الاعتماد على مواقع التواصل الاجتماعي وبدوافع الإنع

$$
\text { وأهداف الاعتمادية. }
$$

المعرفة بقضايا المجتمع السعودي تبعاً لسماتهم

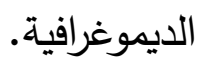
r-توجد فروق ذات دلالة إحصائية في درجة اعتماد

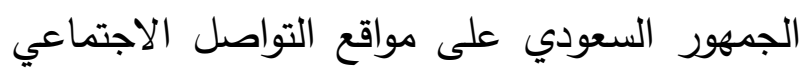

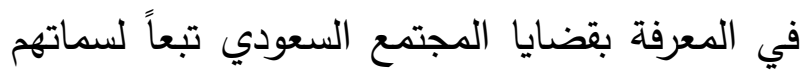
الديموغرافية. ب-توجد علاقة ارتباطية ذات دلالة إحصائية بين درجة اعتماد الجمهور السعودي على مواقع التواصل

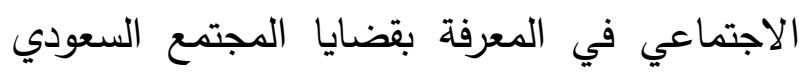
وبين نوعية القضايا التي يحرص الجمهور السعودي لإئي على متابعتها في مواقع التواصل الاجتماعي. ع-توجد علاقة ارتباطية ذات دلالة إحصائية بين درجة اعتماد الجمهور السعودي على مواقع التواصل الاجتماعي في المعرفة بقضايا المجتمع السعودي

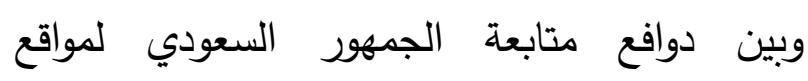
التواصل الاجتماعي. ه-توجد علاقة ارتباطية ذات دلالة إحصائية بين

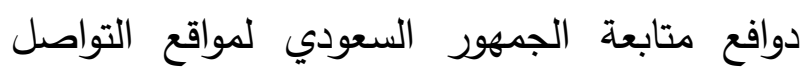

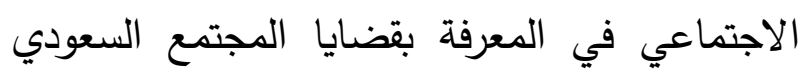

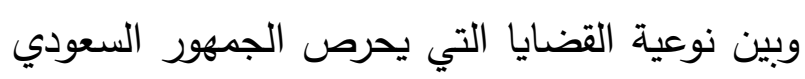
على متابعتها في مواقع التواصل الاجتماعي. ج-توجد علاقة ارتباطية ذات دلالة إحصائية بين

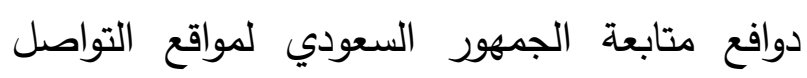

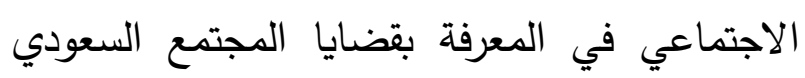

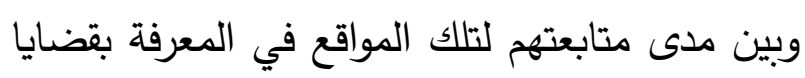

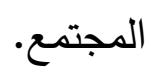


الجزء الثاني: وخصص لقياس الوسائل الإعلامية

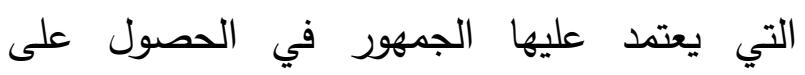
المعلومات حول قضايا المجتمع السعودي. الجزء الثالث: وخصص لقياس مواقع التواصل الاجتماعي والمواقع الإليكترونية التي يعتمد عليها الجمهور في الحصول على المعلومات حول قضايا المجتمع السعودي.

الجزء الرابع: وخصص لقياس درجة اعتماد الجمهور

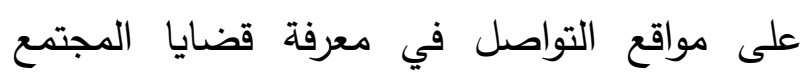
السعودي. الجزء الخامس: وخصص لقياس الدوافع التي تدفع

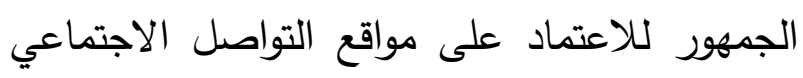
في المعرفة بقضايا المجتمع السعودي.

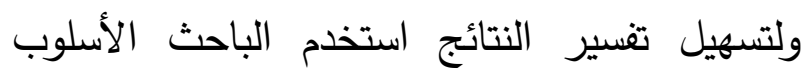

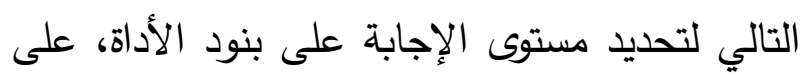

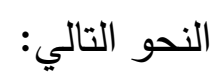
تم إعطاء وزن للبدائل: (بدرجة كبيرة جداً =0، بدرجة

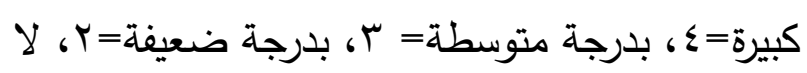

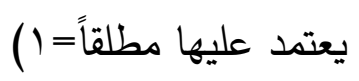

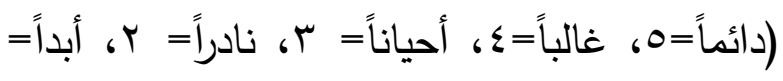
()، ثم تم تصنيف تلك الإجابات إلى خمسة مستويات متساوية المدى من خلال المعادلة التالية:

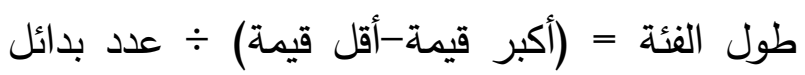
الأداة = (1-0) التصنيف التالي:

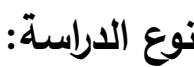

تندرج هذه الدراسة ضمن الدراسات الوصفية والتي

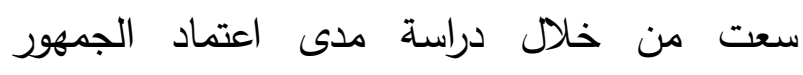

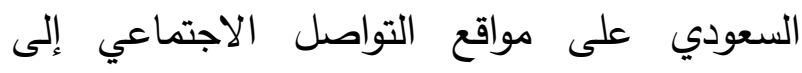
التعرف على مواقع التواصل الاجتماعي التي يعتمد التعاصدي

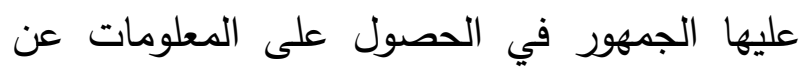

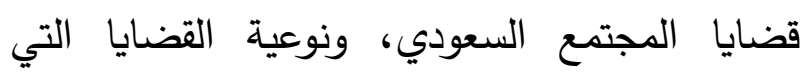
يحرص الجمهور على متابعتها، ودرجة اعتماد الجمهور على هذه المواقع في المعرفة بقضايا

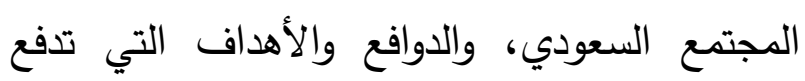

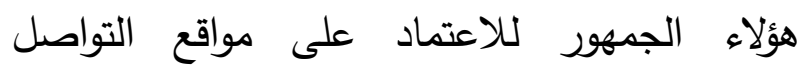
الاجتماعي في المعرفة بقضايا المجتمع السعودي. منهج الدراسة:

تعتمد هذه الدراسة على منهج المسح فهو الأنسب

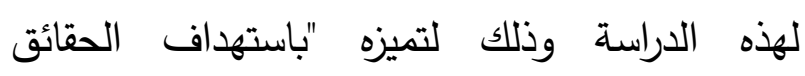
التفصيلية عن واقع الظاهرة المدروسة مما يمكن لهاهن الباحث من تقديم وصف شامل ودقيق لذلك الواقع."

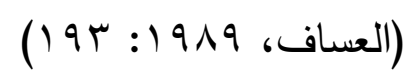

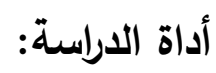

استخدم الباحث الاستبانة أداة ضرورية للحصول على المعلومات الرئيسية للدراسة من أفراد العينة من الإنة

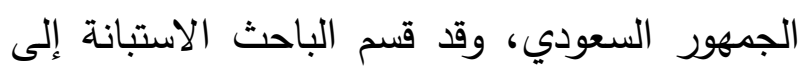
خمسة أجزاء على النحو الآتي: الجزء الأول: وخصص للسماء على الديمو الاتي: الجيمغرافية لأفراد العينة (الجنس، والحالة الاجتماعية، والسن، والدخل الشهري، والمؤهل العلمي، والمهنة). 


\begin{tabular}{|c|c|c|}
\hline المتوسطات & الوصف & الوصف \\
\hline $0, \ldots-\varepsilon, Y)$ & دائماً & بدرجة كبيرة جداً \\
\hline$\Sigma, r \cdot-r, \Sigma)$ & غالباً & بدرجة كبيرة \\
\hline$r, \varepsilon \cdot-r, r)$ & أحياناً & بدرجة متوسطة \\
\hline$r, T \cdot-1, \lambda 1$ & 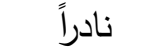 & بدرجة ضعيفة \\
\hline $1, \wedge,-1, \cdots$ & لا يستخدمها & لا يعتمد عليها \\
\hline
\end{tabular}

وتوزيع رابط الاستبانة (https://drive.google.com) عبر البريد الإليكتروني وموقع التواصل الاجتماعي

$$
\begin{aligned}
& \text { (تويتر). (جوني، } 10 \text { • r: rTr) } \\
& \text { تحليل المعلومات: }
\end{aligned}
$$

تم استخدام برنامج (SPSS) لتحليل البيانات الكمية وفق المعايير الإحصائية المتعددة، واستخدم الباحث عدداً من الأساليب الإحصائية لوصف الإصليه لنتائج

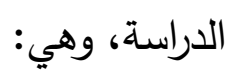

1-معامل ارتباط (Pearson) لقياس التحقق من

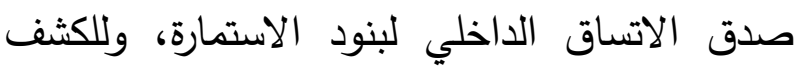
عن مدى وجود علاقات دالة إحصائياً بين إجابات الاتيات المبحوثين وعدد من المتغيرات. ب-معاملات ثبات ألفا كرونباخ لقياس معاملات ثبات محاور الدراسة.

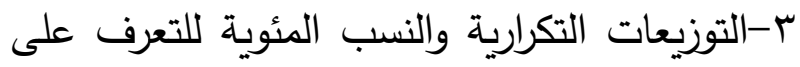
تكرارات الإجابات لدى المبحوثين. ع-المتوسط الحسابي والانحراف المعياري.

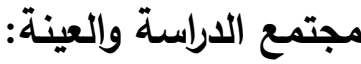

للحصول على المعلومات اللازمة للإجابة عن لناتية تساؤلات الدراسة فإن مجتمع الدراسة هم المواطنين السعوديين في مدينة الرياض؛ وقد حدد الباحث مدينة الرياض لأنها العاصمة، وتمثل المرتبة الأول من حيث الكثافة السكانية من بين مدن المملكة العربية السعودية حسب إحصاءات الهيئة العامة للإحصاء لعام V V I rم، بالإضافة إلى تنوع تركيبة مدينة الرياض السكانية ومن مختلف الطبقات والفئات والسكان المستقرين بها: فهم تقريباً يمثلون معظم مناطق ومدن المملكة، الأمر الذي يجعلها تعبر إلى حد ما عن واقع المجتمع السعودي ( الباحث بتوزيع الاستبانة بطريقة العينة المتاحة لأن المسح الإليكتروني لا يتيح آلية لسحب عينة عشوائية من مفردات عينة الدراسة، وقد بلغ حجم العينة

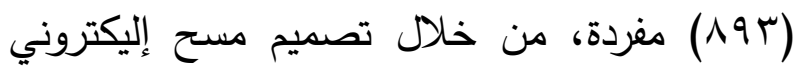
(Google Drive) على موقع (Online Survey) 


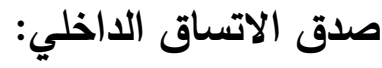
وللتحقق من صدق الاستبانة قام الباحث بحساب صدق الاتساق الاخلي باستخدام معامل ارتباط بيرسون (Pearson) للاستبانة بالدرجة الكلية للمحاور الدراسة، وقد أظهرت النتائج أن جميع معاملات ارتباط عبارات

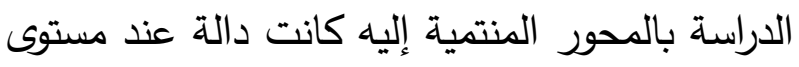

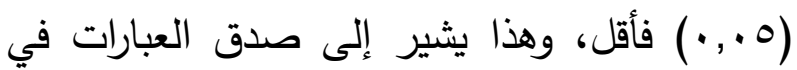

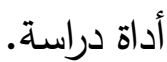

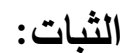

للتأكد من ثبات استبانة دراسة اعتماد الجمهور

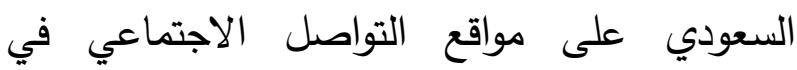
المعرفة بقضايا المجتمع قام الباحث باستخدام معامل ثبات (ألفا كرومباخ) لمحاور الدراسة حيث أظهرت النتائج كما يبين الجدول رقم (Y) أن محاور الاستبانة تتمتع بثبات جيد، وهذا يشير إلى ثبات أداة الدراسة وصلاحيتها للتطبيق.
ه-اختبار (ت) لبيان مدى وجود فروق دالة إحصائياً بين إجابات المبحوثين تبعاً لسماتهم الرئيسية. צ-تحليل التباين الأحادي (On Way Anova) لبيان مدى وجود فروق دالة إحصائياً بين إجابات المبحوثين على بعض جوانب الدراسة المختلفة.

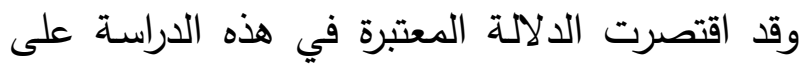
مستوى (0.,.•)، واقتصر الباحث في هذه الدراسة على النتائج التي تتوافر على هذا المستوى من

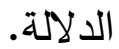

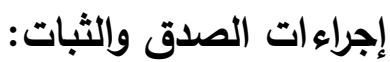

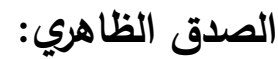
1-للتأكد من صدق الاستبانة المستخدمة في هذه الدراسة قام الباحث بصياغة أسئلة الاستبانة المتعلقة بمتغيرات الدراسة صياغة واضحة، بحيث يمكن فهم محتواها من قبل المبحوثين. r-تم عرض الاستبانة ومشكلة الدراسة وتساؤلاتها

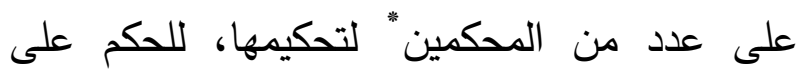
مدى صلاحيتها للقياس، وقد أخذ الباحث بملحوظات لمنات المحكمين وتعديلاتهم حيث أفاد منها في إعادة صياغة بعض الأسئلة حتى أصبحت الاستبانة

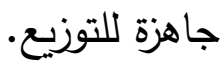

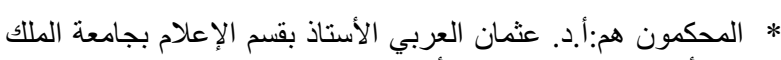

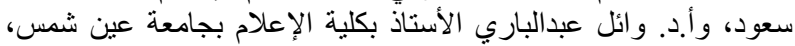

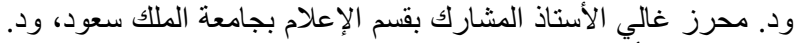

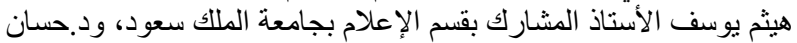

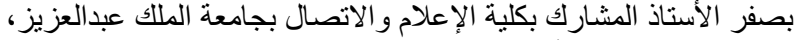
ود. عايض الحربي الأستاذ المساعد بقسم الإعلام بجامعة الملك سعود د. 
جدول رقم (r) معاملات ثبات ألفا كرونباخ لمحاور الدراسة (العينة الاستطلاعية: ن=V ؛)

\begin{tabular}{|c|c|c|}
\hline معامل ثبات ألفا & عدد البنود & المحور \\
\hline$\cdot, \mathrm{V}$ & $\wedge$ & درجة الاعتماد على وسائل الإعلام للحصول على معلومات عن قضايا المجتمع \\
\hline$\cdot$, , & 1 & المجتمع الاعتمـاد على المواقع الإلكترونيـة للحصول على معلومـات عن قضـايا \\
\hline$\cdot, \mathrm{AV}$ & 11 & دضايا الهجتمع الاعتماد على مواقع التواصل الاجتماعي للحصول على معلومات عن \\
\hline •, 94 & 11 & الاجتماعي التضيا التي يحرص المجتــع السـعودي على متابعتهـا في مواقع التواصل \\
\hline$\cdot, \wedge \varepsilon$ & ir & أسباب الاعتماد على مواقع التواصل الاجتماعي في معرفة قضايا المجتمع \\
\hline$\cdot, 9 \vee$ & $1 \varepsilon$ & الاجتماعي في معرفة قضايا المجتمع الأهداف التي تدفع الجمهر السعودي للاعتماد على مواقع التواصل \\
\hline
\end{tabular}

أولاً: السمات الديموغرافية لأفراد عينة الدراسة:

توضح الجداول الآتية السمات الديموغرافية لأفراد العينة التي بلغت ستة متغيرات هي: الجنس، والحالة الاجتماعية، والسن، والدخل الثهري، والمؤهل العلمي، والمهنة. 
جدول رقم (ץ) توزيع أفراد العينة وفقاً للسمات الديموغرافية

\begin{tabular}{|c|c|c|c|}
\hline النسبة & 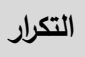 & التصنيف & المتغيرات \\
\hline$\vee \cdot, \cdot$ & rto & 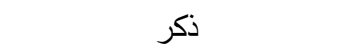 & \multirow{2}{*}{ 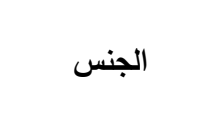 } \\
\hline$r \cdot, \cdot$ & rYA & أنثى & \\
\hline$\wedge \cdot, \uparrow$ & $V Y$. & متزوج & \multirow{2}{*}{ الحالة الاجتماعية } \\
\hline $19, \varepsilon$ & IVT & غير متزوج & \\
\hline$r_{,} \cdot$ & 11 & أقل من · r سنة & \multirow{5}{*}{ 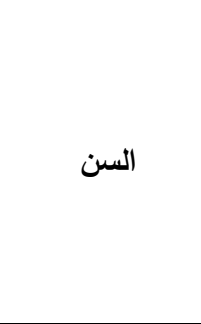 } \\
\hline 11,9 & 179 & من · r إلى أقل من • ب سنة & \\
\hline 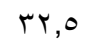 & rq. & من · r إلى أقل من • ـ سنة & \\
\hline$r 0,9$ & Tl & من · ع إلى أقل من · • سنة & \\
\hline $1 \cdot, 7$ & 90 & من ·م سنة فما فوق & \\
\hline$r v, l$ & 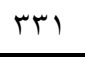 & أكثر من ... & \multirow{5}{*}{ الاخل الثهري الثري } \\
\hline$r_{1,0}$ & 194 & من 1 . . إلى . . . 1 1 ريال & \\
\hline $1 v, 1$ & 101 & من 1 . .0 إلى . . . . ريال & \\
\hline 17,1 & $1 \leq \varepsilon$ & أقل من . . ب ريال & \\
\hline$\wedge, r$ & $V T$ & من 1 . .ب إلى . . . . ريال & \\
\hline or, 1 & $\varepsilon \vee \varepsilon$ & بكالوريوس & \multirow{4}{*}{ المؤهل العلمي } \\
\hline ri,r & 19 & دراسات عليا & \\
\hline $1 \leq, 9$ & س & ثانوي فأقل & \\
\hline $1 \cdot, \wedge$ & 97 & 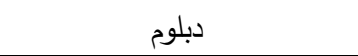 & \\
\hline M,^ & Y^s & موظف/موظفة حكومي & \multirow{8}{*}{ المهنة } \\
\hline YI,T & 194 & موظف/موظفة قطاع خاص & \\
\hline $11, r$ & $1 \ldots$ & متقاعد/ متقاعدة & \\
\hline $9, r$ & Ar & ربة منزل & \\
\hline$\wedge, \varepsilon$ & vo & طالب/ طالبة & \\
\hline$\wedge, 1$ & Vr & صاحب/صاحبة أعمال حرة & \\
\hline $0, r$ & $\varepsilon V$ & بدون عمل & \\
\hline$\varepsilon, 0$ & $\varepsilon$ & موظف عسكري & \\
\hline$\% 1 \ldots$ & А१५ & \multicolumn{2}{|l|}{ المجموع } \\
\hline
\end{tabular}




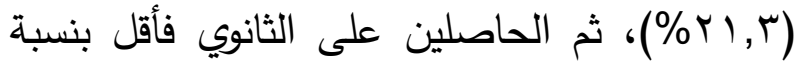

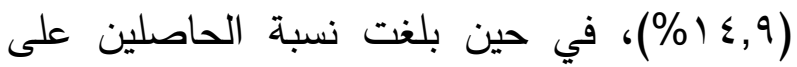
الدبلوم (^, • (\%) من إجمالي المبحوثين.

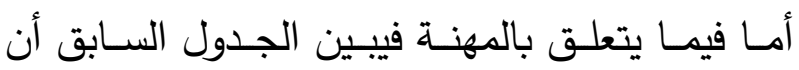
الموظفين الحكوميين (المدنيين) يمثلون أكبر فئة في لي لفي

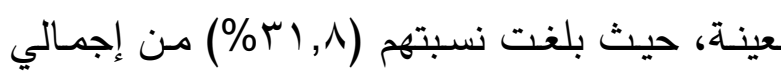
المبحوثين، يليهم في المرتبة الثانية موظفي القطاع

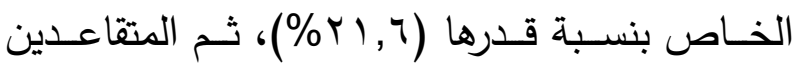

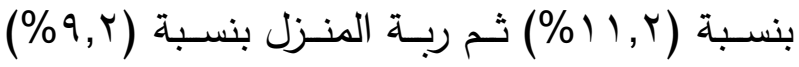
وتقاربـت نسـبة تمثيـل الطـلاب وأصــاب الأعمـال

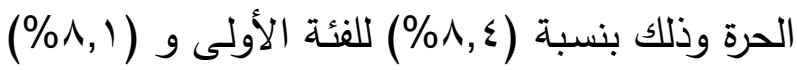
للفئة الثانية، يليهم من لا يعمل بنسبة (؟,0\%)، أما

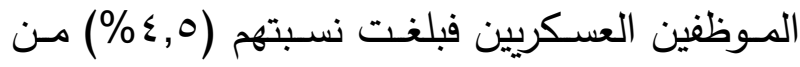

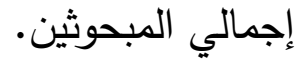
ثانياً: المعلومات الخاصة بالاراسة:
يبين الجدول رقم (r) أن (•У\%) من المبحوثين

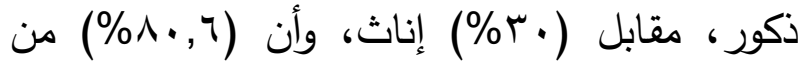
المبحوثين متزوجين، مقابل (؟,9 (1\%) غير متزوج،

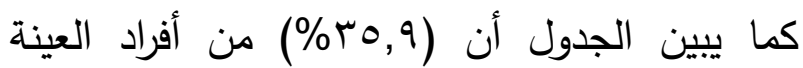

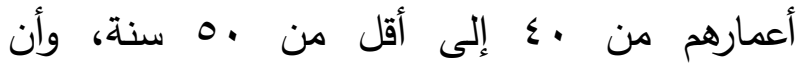

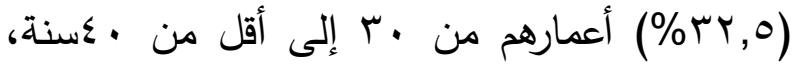

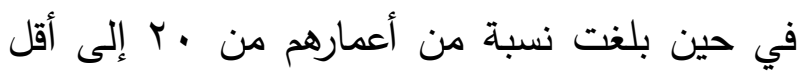

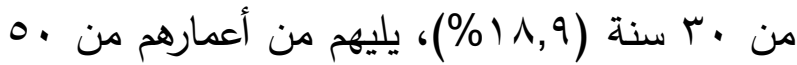

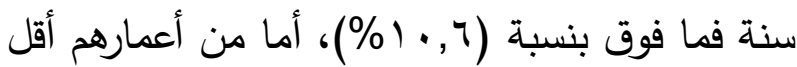
من r r. سنة فبلغت نسبتهم r\%) من إجمالي

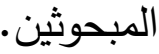
وفيما يتعلق بالاخل الثهري يشير الجدول السابق أن الأفراد الذين دخلهم يزيد عن ...0 اريال بلغت

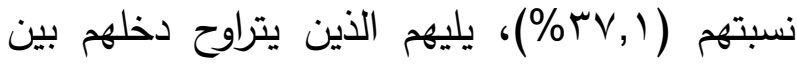

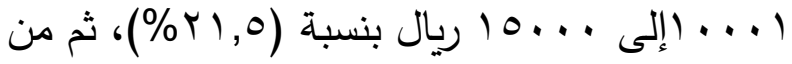
دخلهم من 1... إلى ..... 1. ريال بنسبة قدرها (\%) V,l) وذلك بنسبة قدرها (17 (1\%)، كما يبين الجدول

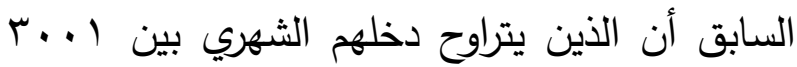
إلى ... .0 ريال يمثلون أقل الفئات تمثيلاً في هذه لتهرين

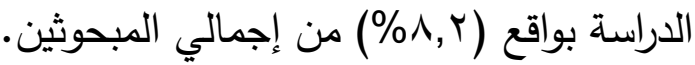

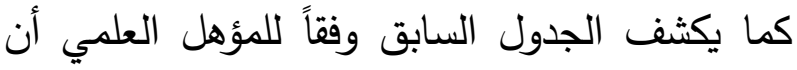
أفراد العينة من الحاصلين على البكالوريوس هم

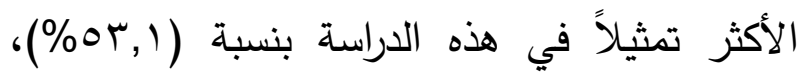

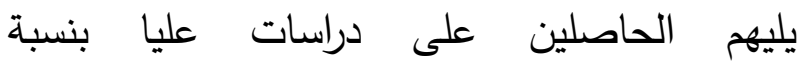


ا-الوسائل الإعلامية التي يعتمد عليها أفراد العينة في الحصول على المعلومات عن قضايا المجتمع: جدول رقم (؛ ) الوسائل الإعلامية التي يعتمد عليها أفراد العينة في الحصول على المعلومات عن قضايا المجتمع

\begin{tabular}{|c|c|c|c|}
\hline درجة الاعتماد & الانحراف المعياري & الحسابي * المتوسط & الوسبائل \\
\hline دائهاً & س & $\varepsilon, 0$ r & الإنترنت \\
\hline غالباً & $1, r$ & $r, \leqslant 7$ & القنوات الفضائية الإخبارية العربية \\
\hline أحياناً & $1, Y r$ & $r, \wedge \wedge$ & التلفزيون السعودي \\
\hline نادراً & $1, r V$ & $r, O \wedge$ & باللغة العربية الفضائية الإخبارية الأجنبية \\
\hline 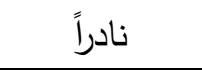 & 1,17 & r, rی & إذاعات أف إم \\
\hline 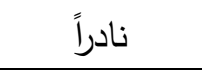 & 1,19 & r, & الصحف السعودية اليومية المطبوعة \\
\hline 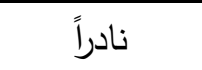 & $1,1 r$ & $r, r$. & الإذاعة السعودية \\
\hline 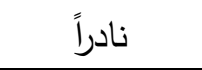 & $1,1 \leq$ & $r, r$ & الصحف العربية والدولية اليومية \\
\hline
\end{tabular}

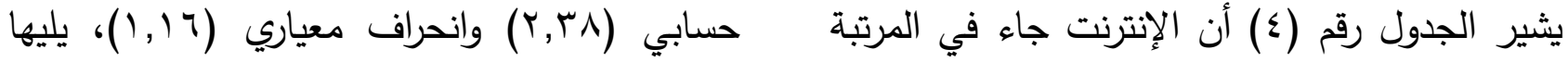
الأولى في الوسائل الإعلامية التي يعتمد عليها أفراد الصحف السعودية اليومية المطبوعة في المرتبة العينة في الحصول على المعلومات عن قضايا السادسة بمتوسط حسابي (r,Y) وانحراف معياري

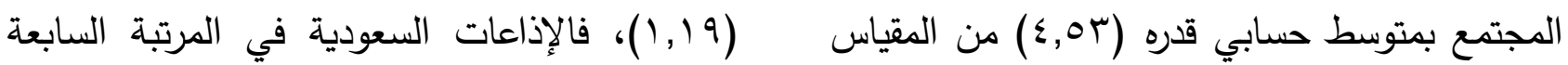

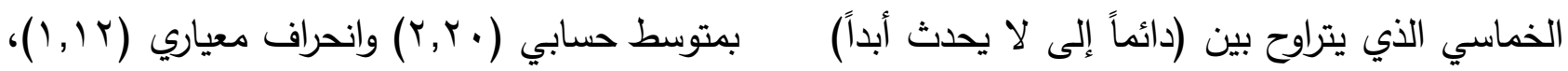
وانحراف معياري (זی,••)، يليه في المرتبة الثانية ويظهر الجدول أن الصحف العربية والدولية اليومية

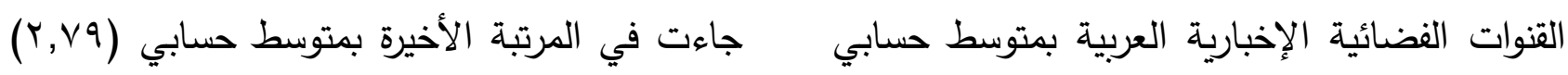

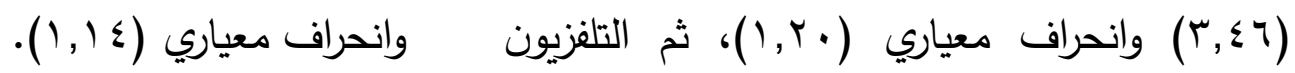
السعودي في المرتبة الثالثة بمتوسط حسابي (^,^ی) وانحراف معياري (Y, , ( ))، وجاءت القنوات الفضائية الإخبارية الأجنبية باللغة العربية في المرتبة الرابعة

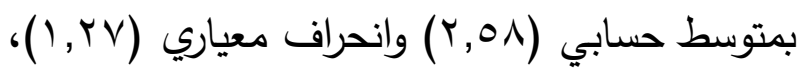
ثم إذاعات (FM) في المرتبة الخامسة بمتوسط 
ץ-المواقع الإليكترونية التي يعتمد عليها أفراد العينة في الحصول على المعلومات عن قضايا المجتمع: جدول رقم (ه) المواقع الإليكترونية التي يعتمد عليها أفراد العينة في الحصول على المعلومات عن قضايا المجتمع

\begin{tabular}{|c|c|c|c|}
\hline درجة الاعتماد & الانحراف & المتوسط & المواقع الإليكترونية \\
\hline بدرجة كبيرة & $1, r 9$ & $r, \leq \uparrow$ & المواقع الإخبارية \\
\hline بدرجة متوسطة & $1, r v$ & r, & مواقع الجهات الحكومية \\
\hline بدرجة متوسطة & $1, Y_{T}$ & $r, r_{1}$ & الإليكترونية $\quad$ مواقع \\
\hline بدرجة متوسطة & $1, r V$ & $r, v$. & 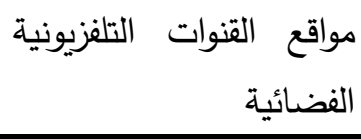 \\
\hline بدرجة ضعيفة & 1,19 & $r, r \wedge$ & مواقع الصحف الورقية \\
\hline بدرجة ضعيفة & 1,1 . & $r, \cdot r$ & مواقع الإذاعات \\
\hline
\end{tabular}

يبين الجدول رقم (0) أن المواقع الإخبارية جاءت الصحف الإليكترونية في المرتبة الثالثة بمتوسط

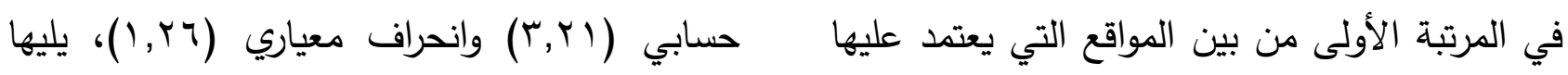
أفراد العينة في الحصول على المعلومات عن قضايا مواقع القنوات التلفزيونية الفضائية بمتوسط حسابي المجتمع بمتوسط حسابي قدره (r,O, الخماسي الذي يتراوح بين (أعتمد عليها بدرجة كبيرة الورقية في المرتبة الخامسة بمتوسط حسابي (^,r) جداً إلى لا اعتمد عليها مطلقاً)، يليها في المرتبة وانحراف معياري (1, (1)، أما مواقع الإذاعات الثانية مواقع الجهات الحكومية بمتوسط حسابي فجاءت في المرتبة الأخيرة بمتوسط حسابي (Y, (Y)

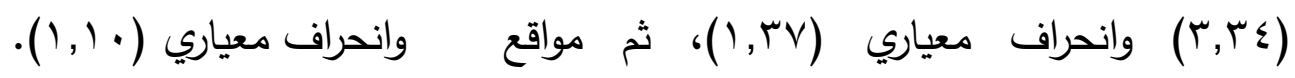


ب-مواقع التواصل الاجتماعي التي يعتمد عليها الجمهور السعودي في المعرفة بقضايا المجتمع السعودي: جدول رقم (†) مواقع التواصل الاجتماعي التي يعتمد عليها أفراد العينة في المعرفة بقضايا المجتمع السعودي المجتمع

\begin{tabular}{|c|c|c|c|}
\hline درجة الاعتماد & الانحراف & المتوسط & مواقع التواصل \\
\hline بدرجة كبيرة جداً & $1, \cdot r$ & $\varepsilon, \varepsilon \varepsilon$ & تويتر \\
\hline بدرجة كبيرة & $1, r V$ & $r, 0$. & الواتسب \\
\hline بدرجة متوسطة & $1, \varepsilon r$ & r,VA & سناب شات \\
\hline بدرجة متوسطة & $1, r$. & $r, V \tau$ & اليوتيوب \\
\hline بدرجة ضعيفة & 1, & $r, \varepsilon)$ & انستجرام \\
\hline بدرجة ضعيفة & $1, r$ & $r, \cdot \Lambda$ & جوجل بلس \\
\hline لا يعتمد عليهاً & $1, .0$ & $1, \wedge$. & الفيسبوك \\
\hline لا يعتمد عليها & $1, \cdot r$ & $1, V_{7}$ & تيلجرام \\
\hline لا يعتمد عليهاً & •, 9 & $1,7 V$ & المدونات \\
\hline لا يعتمد عليها & $\cdot, 9 \leq$ & 1,71 & لينكد إن \\
\hline لا يعتمد عليهاً & $\cdot, \vee \wedge$ & $1, \leqslant 0$ & ماي سبيس \\
\hline
\end{tabular}

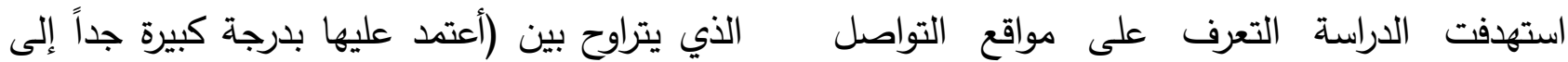

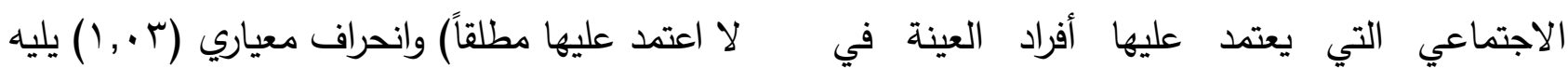

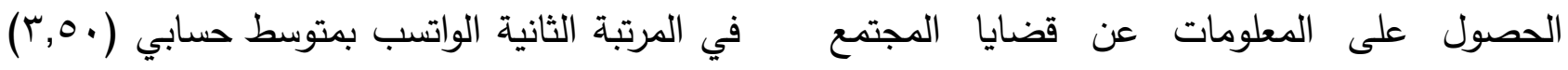

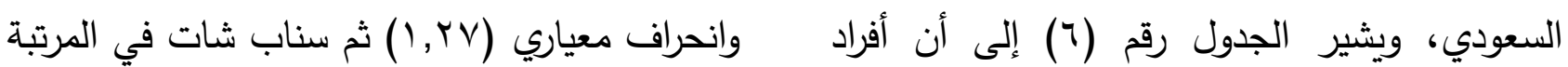
العينة يعتمدون على تويتر بدرجة كبير جداً في الثالثة بمتوسط حسابي (Y,AV) وانحراف معياري

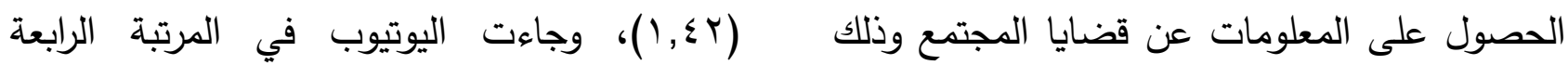

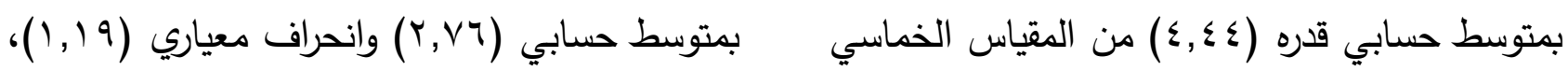


وانحراف معياري (0., ()، يليه في المرتبة التاسعة المدونات بمتوسط حسابي (TV, آ ) وانحراف معياري (r) (•)، ثم لينكد إن في المرتبة العاشرة بمتوسط حسابي (1,7, (1) وانحراف معياري (؟ 9, •)، ويظهر الجدول أن ماي سبيس جاء في المرتبة الأخيرة

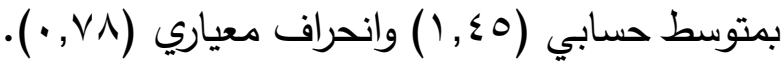
ع - درجة اعتماد الجمهور السعودي على مواقع التواصل الاجتماعي في المعرفة بقضايا المجتمع السعودي: جدول رقم (V) درجة اعتماد الجمهور السعودي على مواقع التواصل الاجتماعي في المعرفة بقضايا المجتمع السعودي العياي

\begin{tabular}{|c|c|c|c|}
\hline درجة المتابعة & الانحراف & الحسابي" المسط & القضايا \\
\hline بدرجة كبيرة & $\cdot, 99$ & $\varepsilon, 17$ & التضايا الاجتماعية \\
\hline بدرجة كبيرة & I,IV & r,A〉 & القضايا السياسية \\
\hline بدرجة كبيرة & 1,11 & r,Ar & القضايا الصحية \\
\hline بدرجة كبيرة & $1,1$. & $r, V \uparrow$ & القضايا الاقتصادية \\
\hline بدرجة كبيرة & 1,14 & r, vo & القضايا التعليمية \\
\hline بدرجة كبيرة & $1, r$. & $r, \uparrow$ & القضايا العلمية والتتنية \\
\hline بدرجة كبيرة & $1, \varepsilon r$ & $r, \uparrow$ & القضايا الرياضية \\
\hline بدرجة كبيرة & I, r & T,TV & والأمنية $\quad$ القضايا $\quad$ العسكرية \\
\hline بدرجة كبيرة & $1, r_{0}$ & $r, 74$ & القضايا الدينية \\
\hline بدرجة كبيرة & 1,11 & $r, 00$ & القضايا الثقافية \\
\hline بدرجة متوسطة & אז, & $\Gamma, \Gamma \varepsilon$ & القضايا الفنية \\
\hline
\end{tabular}

التي يعتمد أفراد العينة على مواقع التواصل لاجتماعي في متابعتها وذلك بمتوسط حسابي (7, ( 2 ) من المقياس الخماسي الذي يتراوح بين

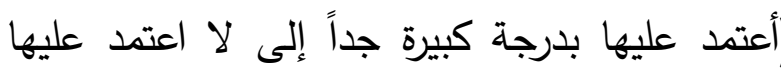

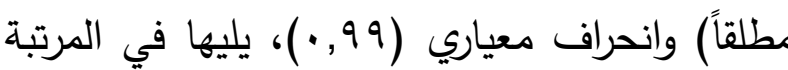

ثم الانستجرام بمتوسط حسابي (1) (Y, وانحراف

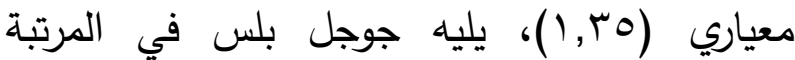

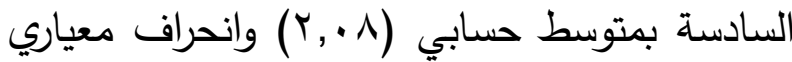
(•, (l)، ثم الفيسبوك في المرتبة السابعة بمتوسط

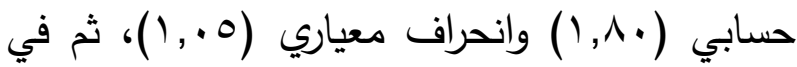
المرتبة الثامنة تيلجرام بمتوسط حسابي (1,VT) 


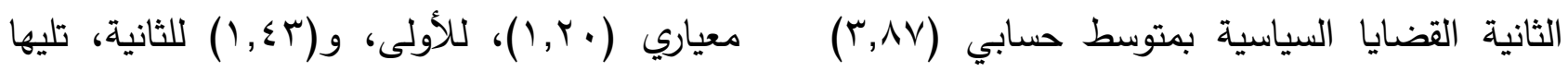

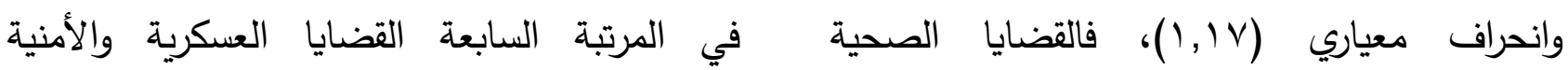

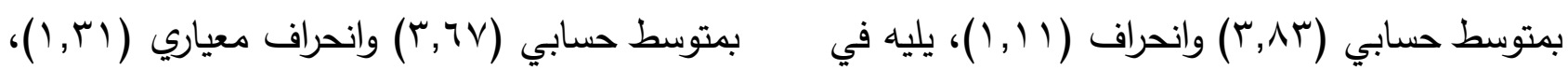

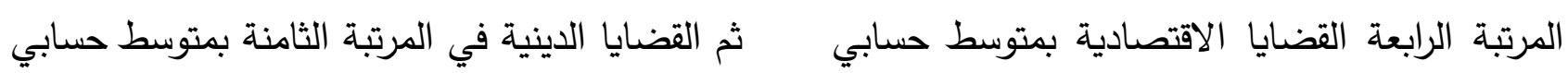

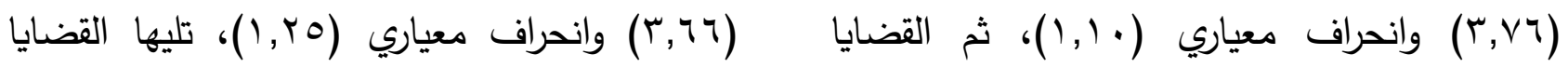

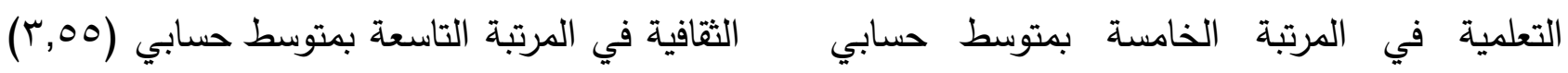

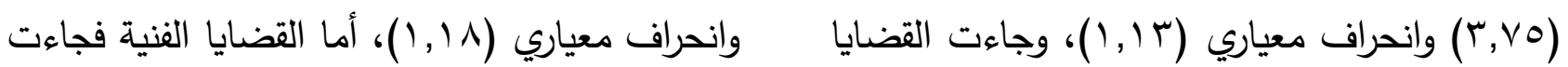

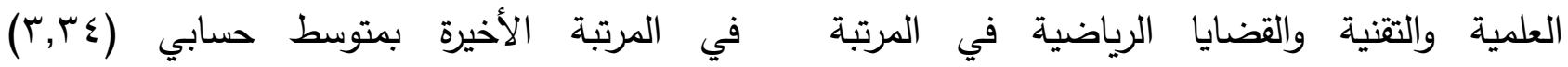

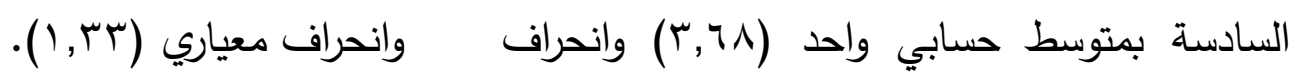
ه-درجة اعتماد الجمهور السعودي على مواقع التواصل الاجتماعي في الحصول على المعلومات عن عن قضائاسيا المجتمع:

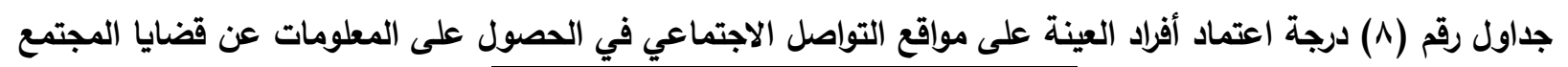

\begin{tabular}{|c|c|c|}
\hline النسبة & التكرار & درجة الاعتماد \\
\hline or,. & $\leqslant 7 \varepsilon$ & يعتمد عليها بدرجة \\
\hline$\varepsilon r,$. & rVo & يعتمد عليها إلى حد \\
\hline ఛ,. & $0 \leqslant$ & لا يمكن الاعتماد \\
\hline$\%$ & س9: & $\| u^{\prime}$ \\
\hline 101. & הभा & الإجمالي \\
\hline
\end{tabular}

يكثف الجدول رقم (^) أن (ro\%) من أفراد العينة المجتمع، في حين أن (r£\%) يعتمدون عليها بشكل

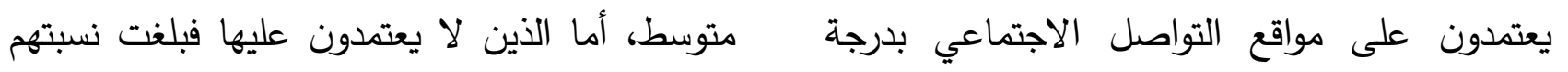
كبيرة في الحصول على المعلومات عن قضايا (†\% من من إجمالي المبحوثين. 
مدى اعتماد الجمهور السعودي على مواقع التواصل الاجتماعي في المعرفة بقضايا المجتمع: دراسة مسحية في مدينة الرياض

צ-أسباب اعتماد أفراد العينة على مواقع التواصل الاجتماعي في المعرفة بقضايا المجتمع السعودي: جدول رقم (9) أسباب اعتماد أفراد العينة على مواقع التواصل الاجتماعي في المعرفة بقضايا المجتمع السعودي

\begin{tabular}{|c|c|c|}
\hline الانحراف & المتوسط & الأسباب \\
\hline$\cdot, r V$ & 1,94 & السرعة في تغطية القضايا والأحداث مع إمكانية التحديث وتصحيح الأخطاء \\
\hline$\cdot, Y V$ & $1,9 r$ & لأنها أصبحت أحد أثكال الإعلام البديل في ظل تراجع دور وسائل الإعلام التقليدية \\
\hline$\cdot, r$ & 1,9 & لألنها ساحة مفتوحة للنقاش المجتمعي وتسمح بتبادل الآراء ووجهات النظر وتصويب \\
\hline 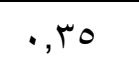 & $1, \wedge 7$ & لأنها تتمتع بدرجة أكبر من حرية الرأي والتعبير مقارنة بغيرها \\
\hline$\cdot+, \varepsilon$ & $1, \wedge 1$ & لأنها تعكس القضايا من منظور المواطنين أنفهه جنبا إلى جنب مع منظور الدولة \\
\hline$\cdot, \sum 1$ & $1, \vee 9$ & لأنها أكثر شمولية وتكاملاً في تغطية الأحداث والقضايا بأدوات وأساليب منطورة \\
\hline$\cdot, \leqslant 1$ & $1, \vee \wedge$ & والأنني صرت أعتمد عليها بشكل كبير في الحصول على معلوماتي تجاه القضايا \\
\hline$\cdot, \varepsilon \varepsilon$ & $1, v \leqslant$ & لأنها تعكس رؤى وتوجهات كل أطراف المجتمع بشكل عادل ومتوازن \\
\hline$\cdot, \leqslant 7$ & $1, V \cdot$ & لأنها أكثر عمقاً في معالجتها للأحداث والقضايا مقارنة بغيرها \\
\hline$\cdot, \leqslant 7$ & $1, V \cdot$ & لأنها تسمح بالتعبير عن رأيي والقدرة على التفاعل معها ومع جمهورها \\
\hline$\cdot, \Sigma \wedge$ & 1,77 & لأنها أكثر مصداقية من غيرها في تتاولها للقضايا \\
\hline$\cdot, \varepsilon \wedge$ & $1,7 r$ & لأن خبرتي السابقة في التعامل معها تؤكد أنها غالبا ما تصدق في تتاولها للقضايا \\
\hline$\cdot, 0$ & 1,01 & لأنها تعبر عن رؤيتي الخاصة تجاه الأحداث والقضايا المجتمية المختلفة \\
\hline
\end{tabular}

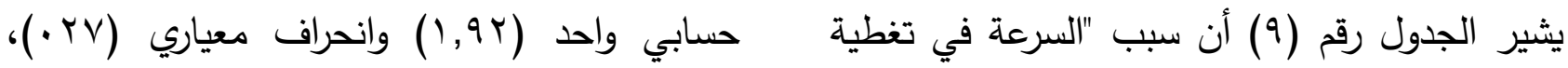
القضايا والأحداث مع إمكانية التحديث وتصحيح يليهما في المرتبة الثانية في قائمة الأسباب التي الأخطاء" وسبب "أن مواقع التواصل الاجتماعي تدفع أفراد العينة في الاعتماد على مواقع التواصل أصبحت أحد أشكال الإعلام البديل في ظل تراجع الاجتماعي "أن مواقع التواصل الاجتماعي ساحة دور وسائل الإعلام التقليدية" جاء في المرتبة مفتوحة للنقاش المجتمعي وتسمح بتبادل الآراء الأولى في قائمة الأسباب التي تدفع أفراد العينة في و ولإعهات النظر وتصويب الأخطاء تجاه ما ينشر " الاعتماد على مواقع التواصل الاجتماعي في وذلك بمتوسط حسابي (·, (1) وانحراف معياري معرفتهم بقضايا المجتمع السعودي وذلك بمتوسط (·, •)، ثم " لأن مواقع التواصل الاجتماعي تتمتع 


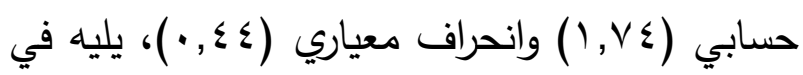
المرتبة الثامنة سبب "لأن مواقع التواصل أكثر عمقاً

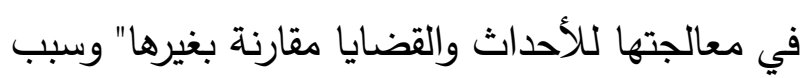
أن مواقع التواصل الاجتماعي تسمح بالتعبير عن

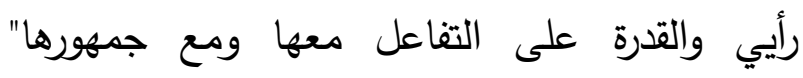

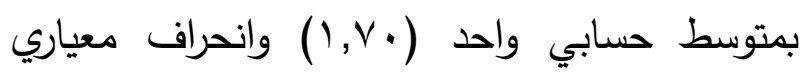

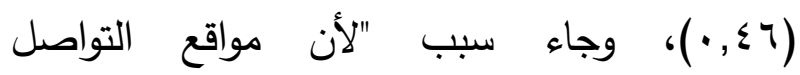
الاجتماعي أكثر مصداقية من غيرها في تتاولها

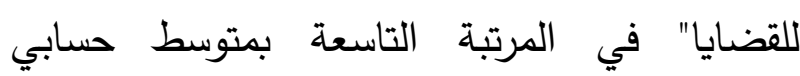

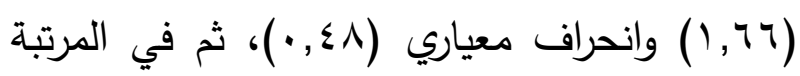

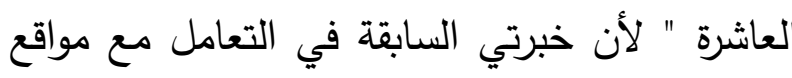
التواصل الاجتماعي تؤكد أنها غالبا ما تصدق في لاني

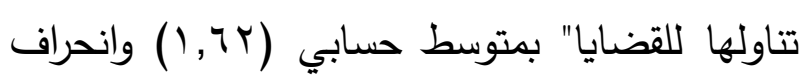

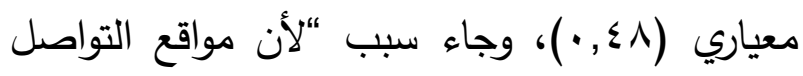
الاجتماعي تعبر عن رؤيتي الخاصة تجاه الأحداث

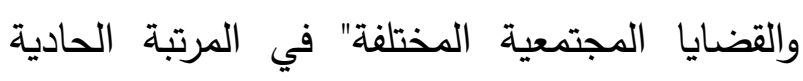
عشر والأخيرة بمتوسط حسابي (1,01) وانحراف

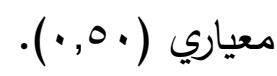

بدرجة أكبر من حرية الرأي والتعبير مقارنة بغيرها"

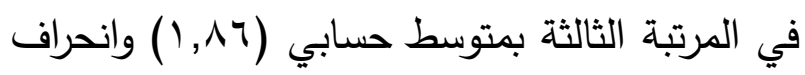

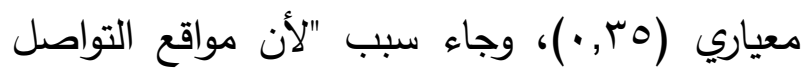
الاجتماعي تعكس القضايا من منظور المواطنين

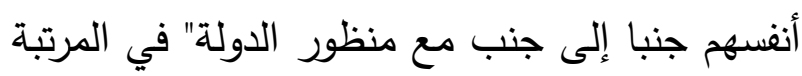
الرابعة بمتوسط حسابي (1), (1) وانحراف معياري ( • , •)، كما يُظهر الجدول السابق أن سبب "لأن

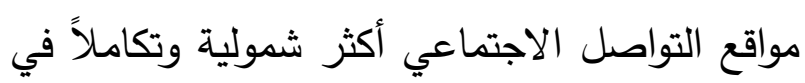

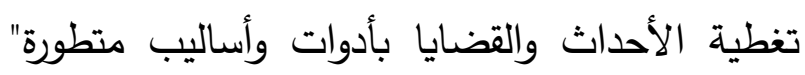

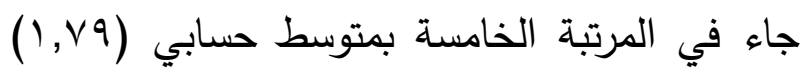
وانحراف معياري (اء (·) )، وجاء سبب "لأنني صرت أعتمد على مواقع التواصل الاجتماعي بشكل كبير

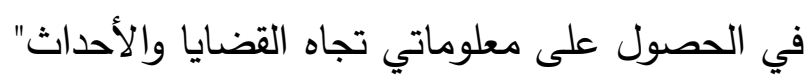

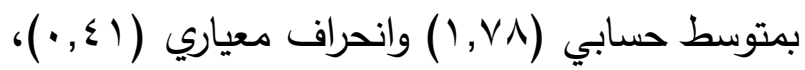

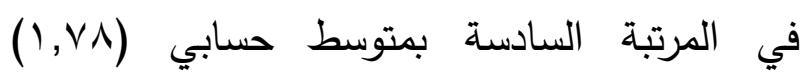
وانحراف معياري (اء,.•)، ثم سبب "أن مواقع التواصل تعكس رؤى وتوجهات كل أطراف المجتمع

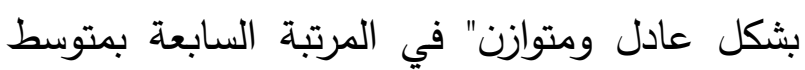


V-دوافع وأهداف اعتماد أفراد العينة على مواقع التواصل الاجتماعي في المعرفة بقضايا المجتمع السعودي: جدول رقم (• 1) دوافع اعتماد أفراد العينة على مواقع التواصل الاجتماعي متابعة قضايا المجتمع

\begin{tabular}{|c|c|c|c|}
\hline 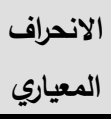 & الحستوسط & 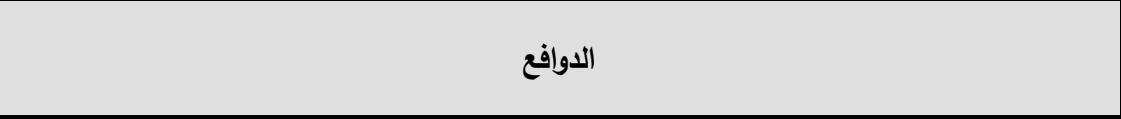 & والألهداف \\
\hline$\cdot, 9 \vee$ & $\varepsilon, 1 \leqslant$ & اعتمد على مواقع التواصل الاجتماعي لأطلع على قضايا المجتمع & \multirow{5}{*}{ :3. } \\
\hline $1, \cdot \varepsilon$ & $\varepsilon, \cdot r$ & اعتمد على مواقع التواصل الاجتماعي للبحث عن المعلومات الجديدة لقضايا المجتمع & \\
\hline $1, .9$ & $r, \Lambda T$ & اعتمد على مواقع التواصل الاجتماعي لأسترشد بما فيها من آراء حول قضايا المجتمع & \\
\hline 1,10 & r,vo & اعتمد على مواقع التواصل الاجتماعي لأنها تساعدني على إدرالك حقائق قضايا المجتمع السعودي & \\
\hline $1,1 \varepsilon$ & $r, v \leq$ & اعتمد على مواقع التواصل الاجتماعي لأنها توفر قضايا مجتمعية صالحة للنقاش مع الآخرين & \\
\hline \multicolumn{2}{|c|}{ r,q1 } & \multicolumn{2}{|l|}{ المتوسط العام للاوافع النفعية } \\
\hline $1, \cdot r$ & $\varepsilon, \cdot 1$ & اعتمد على مواقع التواصل الاجتماعي لمعرفة ما لدى الآخرين من وجهة نظر تجاه قضايا معينة & \multirow{5}{*}{ 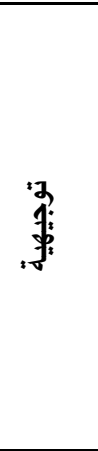 } \\
\hline 1,11 & r,qr & اعتمد على مواقع التواصل الاجتماعي للتفاعل مع قضايا المجتمع & \\
\hline $1,1 \mathrm{r}$ & r,人o & وعدم الانعزال عن قضاياه ومشكلاتله التواصل الاجتماعي لأن المعرفة بهذه القضايا تجعلني أشعر بالانتماء لمجتمعي & \\
\hline $1, r \mathrm{r}$ & r,ov & الإلمام بها على مواقع التواصل الاجتماعي لأنها تتناول قضايا تتصل بمصالحي المباشرة ومن الضرورة & \\
\hline $1, Y v$ & r,ru & |عتد على مواقع التواصل الاجتماعي لتساعدني في اتخاذ القرار والرأي الصائب & \\
\hline \multicolumn{2}{|c|}{$r, v \varepsilon$} & \multicolumn{2}{|l|}{ المتوسط العام للدوافع التوجيهية } \\
\hline $1,1 \leq$ & r,qu & اعتمد على مواقع التواصل الاجتماعي لأنها أصبحت عادة لي & \multirow{4}{*}{ 承: } \\
\hline $1,1$. & r,q1 & |عتمد على مواقع التواصل الاجتماعي للتسلية والترفيه & \\
\hline 1,10 & $r, \mathrm{rl}$ & من القدرة على مواقع التواصل الاجتماعي لأنها تساعدني في فهم الواقع بمشكلاته وتحدياته بما يمكنني & \\
\hline $1, r$ & r,or & اعتمد على مواقع التواصل الاجتماعي لأنها تزودني بالحلول العملية حول الكثير من قضايا المجتمع & \\
\hline \multicolumn{2}{|c|}{$\begin{array}{r}\mathrm{r}, \mathrm{VV} \\
\end{array}$} & \multicolumn{2}{|l|}{ المتوسط العام للدوافع السلوكية } \\
\hline \multicolumn{2}{|c|}{ r,Al } & \multicolumn{2}{|l|}{ 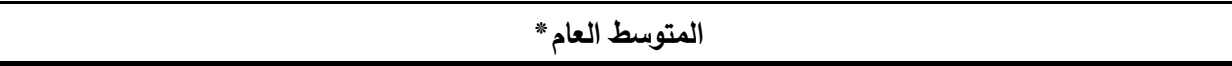 } \\
\hline
\end{tabular}

استهدفت الدراسة التعرف على أهداف ودوافع اعتماد لمتابعة مواقع التواصل الاجتماعي في المعرفة أفراد العينة على مواقع التواصل الاجتماعي في بقضايا المجتمع وذلك بمتوسط حسابي (1,9) من المعرفة بقضايا المجتمع السعودي، والمتمثلة في المقياس الخماسي الذي يتراوح بين (أعتمد عليها الدوافع المنفعية والتوجيهية والسلوكية، ويوضح بدرجة كبيرة جداً إلى لا اعتمد عليها مطلقاً)، يليه في الجدول رقم (· () أن الدوافع النفعية جاءت في المرتبة الثانية الدوافع السلوكية بمتوسط حسابي المرتبة الأولى من بين الدوافع التي تدفع الجمهور 
(r,VV) لمجتمعي وعدم الانعزال عن قضاياه ومشكلاته"

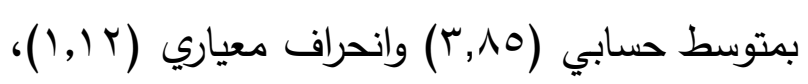
ثم دافع "لأن مواقع التواصل الاجتماعي تساعدني

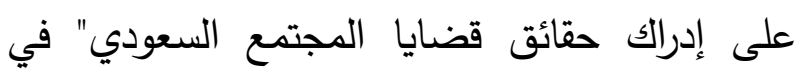
المرتبة التاسعة بمتوسط حسابي (r,Vo) وانحراف إنى معياري (10,1,)، يليه في المرتبة العاشرة دافع " لأن

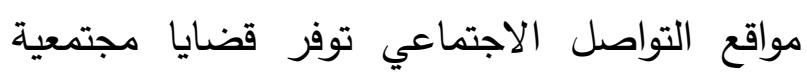
صالحة للنقاش مع الآخرين" بمتوسط حسابي (r,V乏) الحادية عشر دافع " لأن مواقع التواصل الاجتماعي

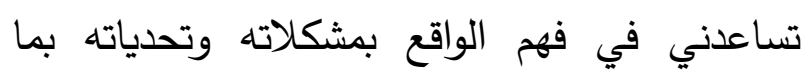
يمكنني من القدرة على التعامل معهة" بمتوسط حسابي

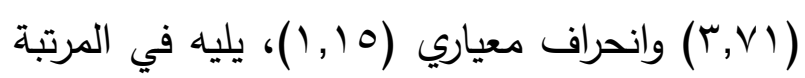
الثانية عشر دافع " لأن مواقع التواصل الاجتماعي

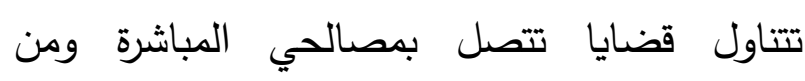
الضرورة الإلمام بها" بمتوسط حسابي (r,OV) وانحراف معياري (Y,Y, (I)، ثم في المرتبة الثالثة عشر دافع " لأن مواقع التواصل الاجتماعي تزودني

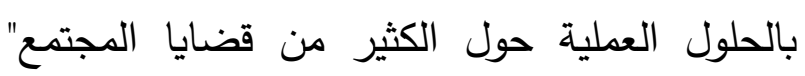

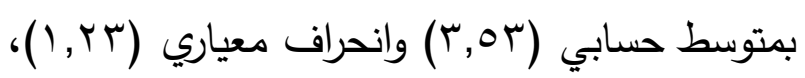
وجاء دافع " لأن مواقع التواصل الاجتماعي

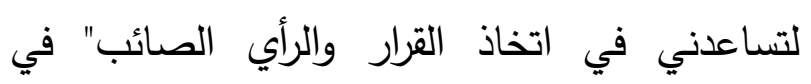
المرتبة الأخيرة بمتوسط حسابي (^^,؟؟) وانحراف

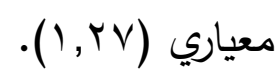

حسابي (r,V

وبالنظر إلى الدوافع السابقة بشكل أكثر تقصيلاً

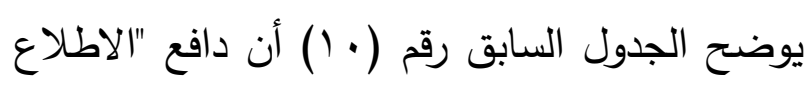

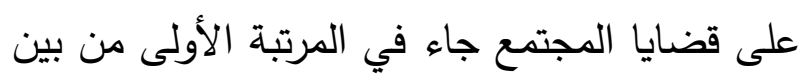

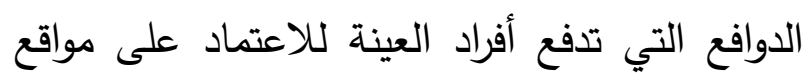

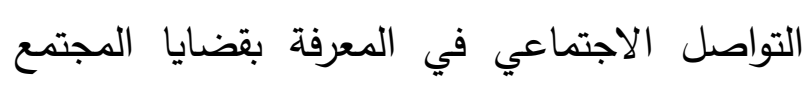

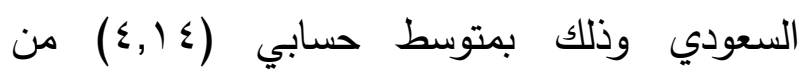
المقياس الخماسي الذي يتراوح بين (أعتمد عليها بدرجة كبيرة جداً إلى لا اعتمد عليها مطلقاً)، وانحراف معياري (9V, ·))، يليه في المرتبة الثانية

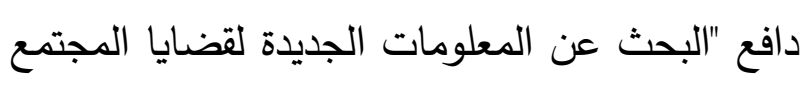

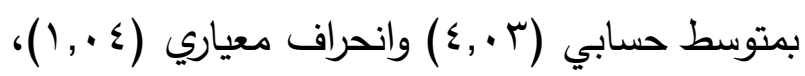
وجاء دافع معرفة ما لاى الآخرين من وجهة نظر الثران

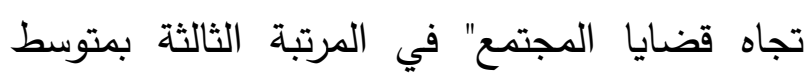

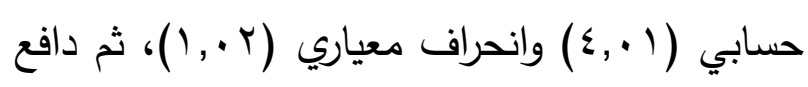

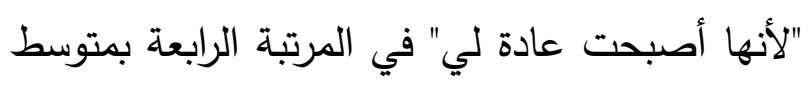

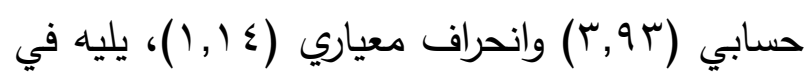

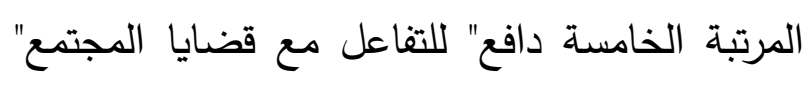

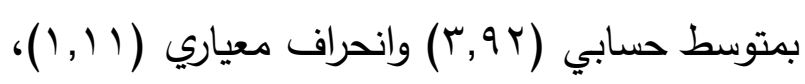
ثم في المرتبة السادسة دافع "التسلية والترفيه"

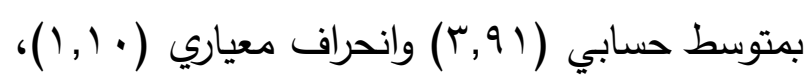
وجاء دافع "الاسترشاد بما في مواقع التواصل

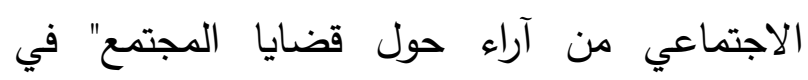

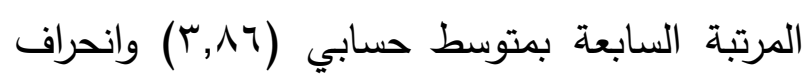
معياري (9 ., ())، يليه في المرتبة الثامنة دافع "أن 
(11) ووفقاً للحالة الاجتماعية أن قيمة (ت) دالة عند مستوى (0.,·)، مما يشير إلى وجود فروق ذات دلالة إحصائية بين استجابات عينة الدراسة حول دوافع متابعتهم لمواقع التواصل الاجتماعي في

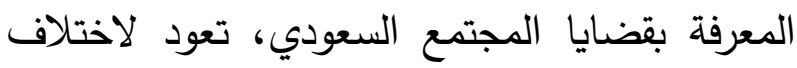
الحالة الاجتماعية لأفراد العينة، حيث بلغت قيمة

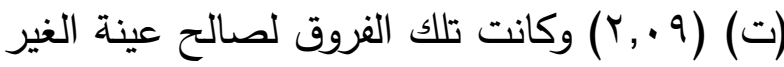

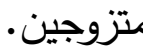

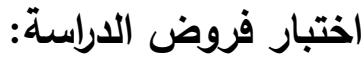
الفرض الأول: توجد فروق ذات دلالة إحصائية في دوافع متابعة الجمهور السعودي لمواقع التواصل الاجتماعي في المعرفة بقضايا المجتمع المعودي تبعاً لسماتهم الايموغرافية: وللتعرف على مدى وجود فروق ذات دلالة إحصائية في دوافع متابعة الجمهور السعودي لمواقع التواصل الاجتماعي في المعرفة بقضايا المجتمع السعودي تبعاً لسماتهم الديموغرافية، يتضح من الجدول رقم جدول رقم (11) الفرق بين أفراد العينة في دوافع متابعتهم لمواقع التواصل الاجتماعي في المعرفة بقضايا المجتمع السعودي

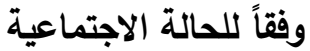

\begin{tabular}{|c|c|c|c|c|c|c|}
\hline التعليق & مستوى الدلالة | & قيمة ت & الانحراف & الحسابي & العدد & الاجتماعية \\
\hline \multirow{2}{*}{ دالة عند مستوى } & \multirow{2}{*}{ •, } & \multirow{2}{*}{$r, . q$} & •,9Y & $r, v \wedge$ & Vr. & متزوج \\
\hline & & & $\cdot, \wedge)$ & r, $q \leq$ & IVT & غير متزوج \\
\hline
\end{tabular}

وفيما يتعلق بالسن يشير تحليل التباين الأحادي كما فروق دالة عند مستوى (0., ·) بين أفراد العينة في

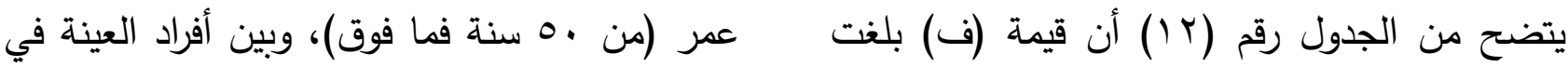

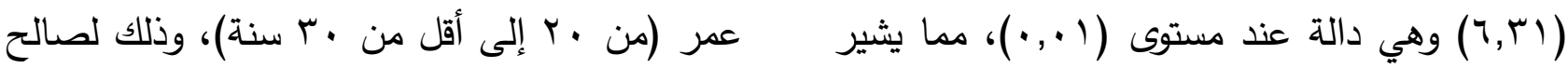

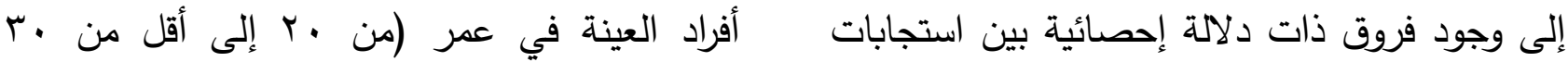

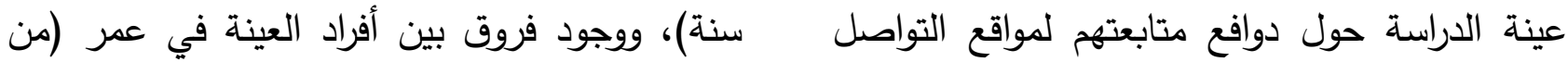

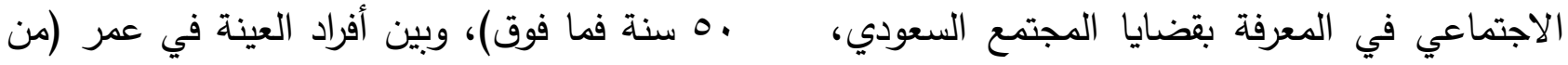

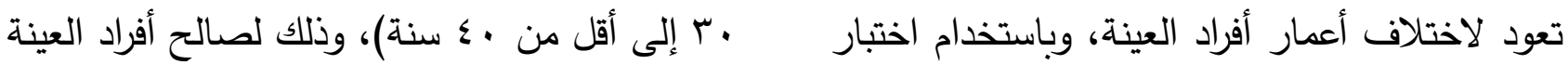
شيفيه للكثف عن مصدر تلك الفروق تبين وجود في عمر (من •r إلى أقل من •ـ سنة). 
جدول رقم (r ا) اختبار تحليل التباين الأحادي لدلالة الفروق في استجابات أفراد العينة حول دوافع متابعتهم لمواقع التواصل الاجتماعي في المعرفة بقضايا المجتمع السعودي وفقاً للسن

\begin{tabular}{|c|c|c|c|c|c|c|}
\hline التعليق & الدلالة & قيمة ف & متوسط المربعات & الحربة & المربعات & مصدر \\
\hline \multirow{2}{*}{ مستوى الة عند . . . } & \multirow{2}{*}{$\cdot, \cdots$} & \multirow{2}{*}{$7, \Gamma_{1}$} & $\varepsilon, 99$ & $\varepsilon$ & $19,9 \leq$ & المجموعات \\
\hline & & & $\cdot, \vee q$ & $\wedge \wedge \wedge$ & $V \cdot 1,7 V$ & داخـــــــل \\
\hline
\end{tabular}

وفيمـا يتعلق بالدخل الثـهري يشـير تحليل التباين العينة، وباستخدام اختبار شيفيه للكثف عن مصدر

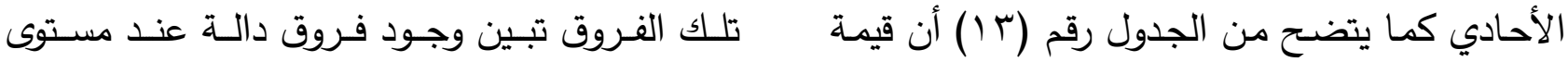

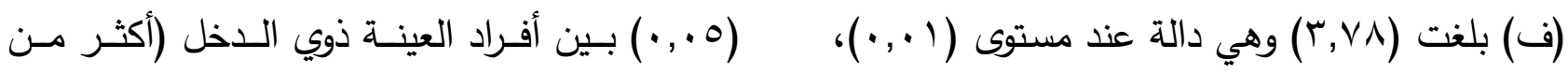

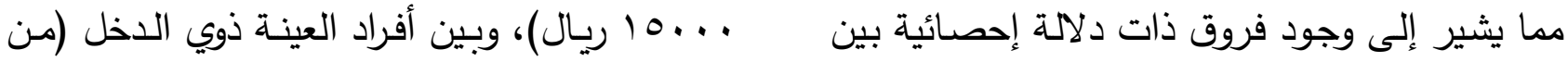

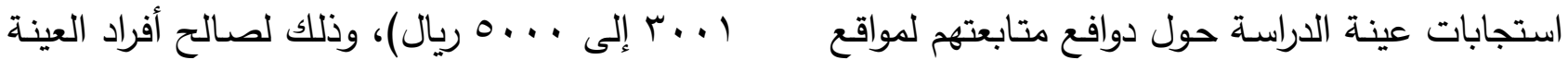

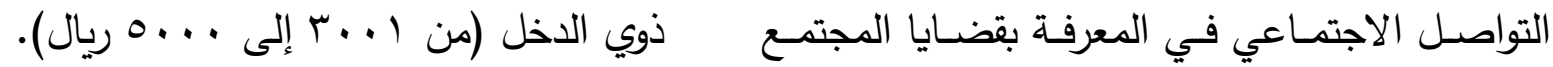

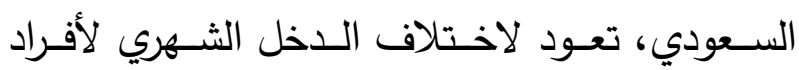
جدول رقم (r ا) اختبار تحليل التباين الأحادي لالالة الفروق في استجابات أفراد العينة حول دوافع متابعتهر لمواقع التواصل الاجتماعي في المعرفة بقضايا المجتمع السعودي وفقاً للدخل الثهري

\begin{tabular}{|c|c|c|c|c|c|c|}
\hline التعليق & مستوى الدلالة & قيمة ف & متوبط المربعات & درجات الحرية & مجموع المربعات & مصدر التباين \\
\hline \multirow{2}{*}{ 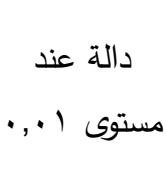 } & \multirow[b]{2}{*}{$\cdot, \cdots 0$} & \multirow[b]{2}{*}{$r, \vee \wedge$} & $r, \cdot r$ & $\varepsilon$ & $1 Y, .9$ & بين المجموعات \\
\hline & & & $\cdot, \wedge$ • & $\wedge \wedge \wedge$ & $V \cdot 9,0 Y$ & المجموعات \\
\hline
\end{tabular}

وفيمـا يتعلق بالمؤهل العلمي يشـير تحليـل التبـاين السـعودي، تعـود لاختـلاف المؤهـل العلمسي لأفـراد

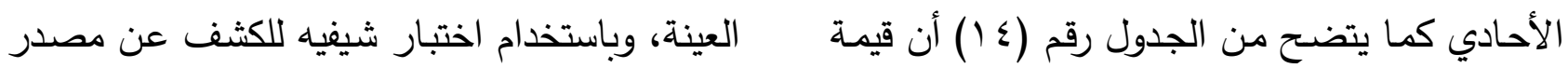

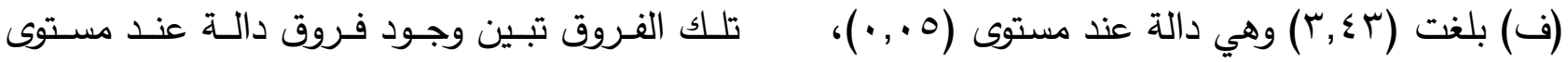

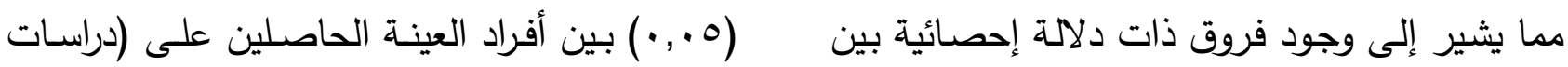

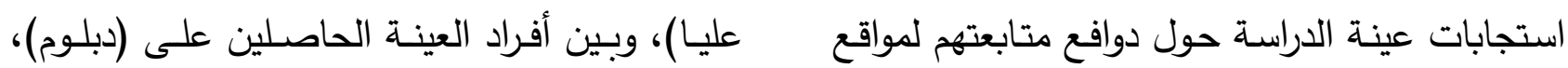
التواصـل الاجتمـاعي في المعرفـة بقضـايا المجتمـع وذلك لصالح أفراد العينة الحاصلين على (دبلوم). 
جدول رقم (ع 1) اختبار تحليل التباين الأحادي لدلالة الفروق في استجابات أفراد العينة حول دوافع متابعتهم لمواقع التواصل الاجتماعي في المعرفة بقضايا المجتمع السعودي وفقاً للمؤهل العلمي

\begin{tabular}{|c|c|c|c|c|c|c|}
\hline التعليق & مستوى الدلالة & قيمة ف & متوسط المربعات & درجات الحرية & مجموع المربعات & مصدر التباين \\
\hline \multirow{2}{*}{ دالة عند مستوى } & \multirow[b]{2}{*}{$\cdot, \cdot, \mathrm{V}$} & \multirow[b]{2}{*}{$r, \varepsilon r$} & r, VO & r & $\Lambda, Y_{O}$ & بين المجموعات \\
\hline & & & $\cdot, \wedge$. & $1 \wedge 9$ & VIr,Ty & المجموعات \\
\hline
\end{tabular}

وفيما يتعلق بالمهنة يشير تحليل التباين الأحادي كما أفـراد العينـة في مهنـة (موظف عسكري)، وذلكك

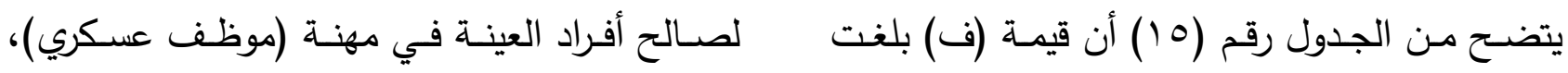

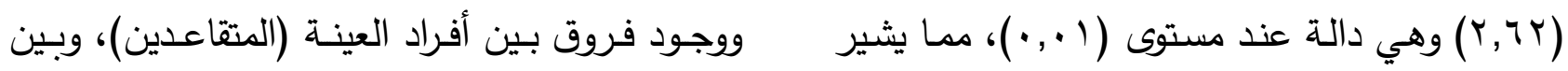
إلى وجود فروق ذات دلالة إحصائية بين استجابات أفراد العينة في مهنة (موظف قطاع خاص)، وذلك

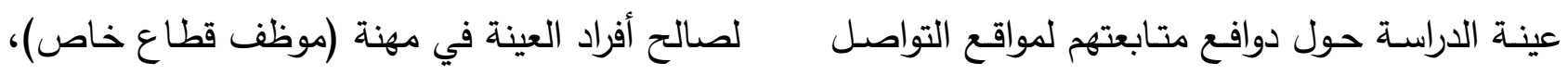
الاجتمـاعي في المعرفة بقضـايا المجتمع السـودي، و وجـود فروق بـين أفراد العينـة (المتقاعدين)، وبين تعود لاختلاف مهنة أفراد العينة، وباستخدام اختبار أفراد عينة (ربـات المنازل)، وذلك لصالح أفراد عينة (LSD) اختبار شيفيه من الكشف عنها تبين وجود فروق دالة فـروق بـين أفـراد العينـة (المتقاعدين)، وبـين أفـراد

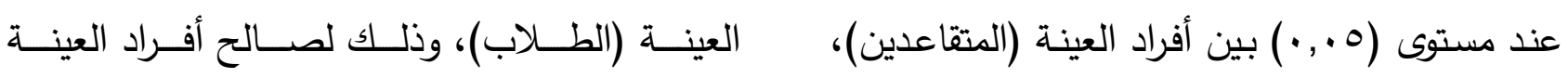
وبين أفراد العينـة في مهنة (موظف حكومي)، وذلك (الطــلاب)، ووجــود فــروق بـين أفــراد العينــة لصـالح أفراد العينـة في مهنـة (موظف حكـومي)، (المتقاعدين)، وبين أفراد العينة اللذين (بدون عمل)، ووجـود فروق بين أفراد العينـة (المتقاعدين)، وبـين وذلك لصالح أفراد العينة اللذين (بدون عمل). جدول رقم (0 1) اختبار تحليل التباين الأحادي لدلالة الفروق في استجابات أفراد العينة حول دوافع متابعتهم لمواقع التواصل الاجتماعي في المعرفة بقضايا المجتمع السعودي وفقاً للمهنة

\begin{tabular}{|c|c|c|c|c|c|c|}
\hline التعليق & مستوى الدلالة & قيمة ف & متوسط المربعات & درجات & المربعات & مصدر التباين \\
\hline \multirow[b]{2}{*}{ مستوى 1 ـ., . } & \multirow[b]{2}{*}{$\cdot, .11$} & \multirow[b]{2}{*}{$r, T Y$} & $r, 1$. & V & $1 \leq, 77$ & بين المجموعات \\
\hline & & & $\cdot, \wedge$. & $\wedge \wedge 0$ & $V \cdot 7,90$ & المجموعات \\
\hline
\end{tabular}

التواصل الاجتماعي في المعرفة بقضايا المجتمع السعودي وفقاً لمتغير الجنس.
ولم تشر نتائج الدراسة إلى وجود فروق ذات دلالة إحصائية في دوافع متابعة الجمهور السعودي لمواقع 
الجدول رقم (7 ( ) ووفقاً للجنس أن قيمـة (ت) دالـة عند مستوى ( ا., ·)، مها يشير إلى وجود فروق

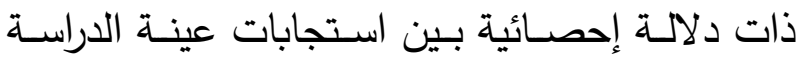
حول اعتمادهم على مواقع التواصل الاجتماعي في لاعلي

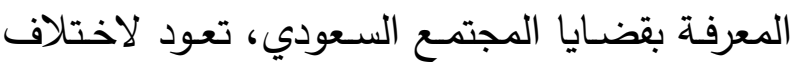

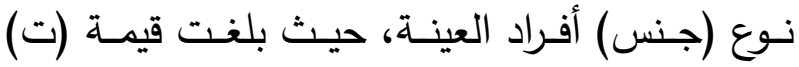
(9, (r, وكانت تلك الفروق لصالح عينة الإناث.

جدول رقم (1 1) الفرق بين أفراد العينة في درجة اعتمادهم على مواقع التواصل الاجتماعي في المعرفة بقضايا المجتمع السعودي وفقاً للجنس

\begin{tabular}{|c|c|c|c|c|c|c|}
\hline التعليق & مستوى اللالالة & قيمة ت & الانحراف المعياري & المتوسط الحسابي & العدد & الجنس \\
\hline \multirow{2}{*}{ دالة عند مستوى } & \multirow{2}{*}{$\cdot, \ldots 1$} & \multirow{2}{*}{$r, 19$} & $\cdot, \mathrm{v}$. & $r, r \varepsilon$ & Tro & ذكر \\
\hline & & & מר & $r, 0$. & rצA & أنثى \\
\hline
\end{tabular}

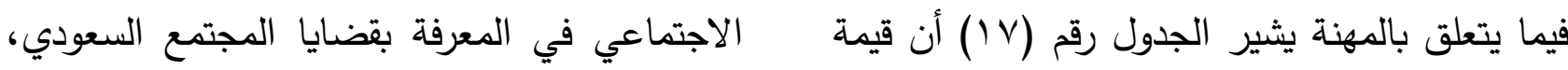

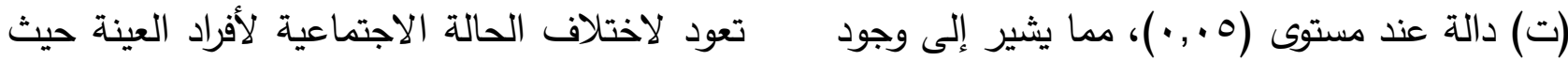

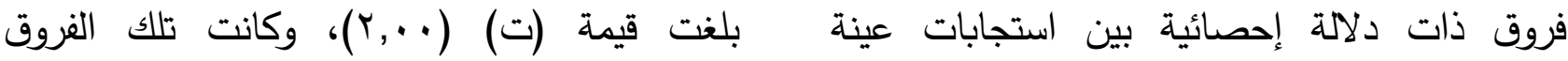

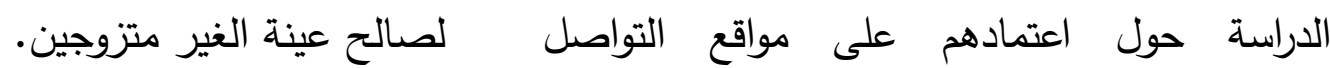
جدول رقم (V) الفرق بين أفراد العينة في درجة اعتمادهم على مواقع التواصل الاجتماعي في المعرفة بقضايا المجتمع

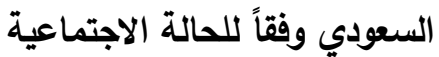

\begin{tabular}{|c|c|c|c|c|c|c|}
\hline التعليق & مستوى الدلالة & قيمة ت & الانحراف المعياري & الحسابي & العدد & الحالة الاجتماعية \\
\hline \multirow{2}{*}{ دالة عند مستوى } & \multirow{2}{*}{.,.$\leqslant V$} & & או, & T, זד & VT. & متزوج \\
\hline & & & $\cdot, V 7$ & $r, \leqslant q$ & IVT & غير متزوج \\
\hline
\end{tabular}

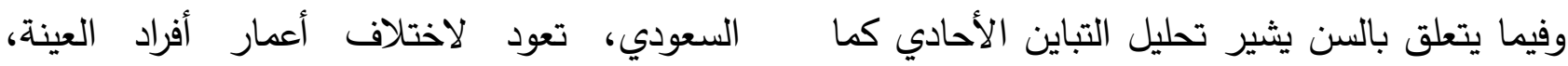

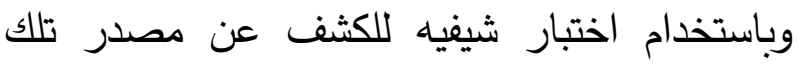

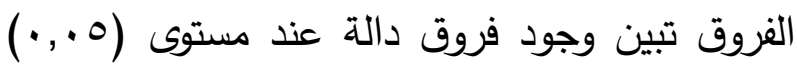

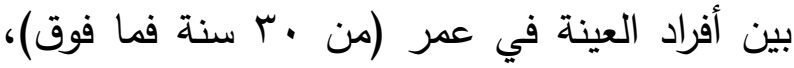

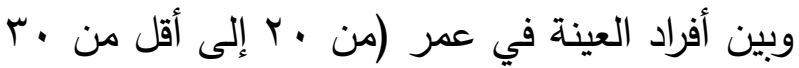

يتضح من الجدول رقم (1) أن قيمة (ف) بلغت

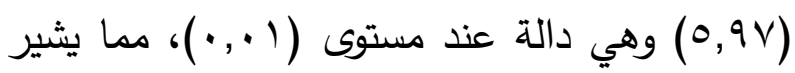
إلى وجود فروق ذات دلالة إحصائية بين استجابات

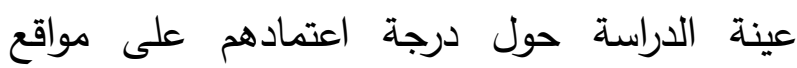
التواصل الاجتماعي في المعرفة بقضايا المجتمع دوليه 


$$
\text { سنة)، وذلك لصالح أفراد العينة في عمر (من ·r ب إلى أقل من ·r سنة). }
$$

جدول رقم (1 ا) اختبار تحليل التباين الأحادي لالالة الفروق في استجابات أفراد العينة حول درجة اعتمادهم

على مواقع التواصل الاجتماعي في المعرفة بقضايا المجتمع السعودي وفقاً للسن

\begin{tabular}{|c|c|c|c|c|c|c|}
\hline التعليق & مستوى الدلالة & قيمة ف & متوسط المربعات & درجات الحرية & مجموع المربعات & مصدر التباين \\
\hline \multirow{2}{*}{ دالة عند مستوى } & \multirow[b]{2}{*}{$\cdot, \cdots$} & \multirow[b]{2}{*}{$0,9 \vee$} & $r, \wedge \uparrow$ & $\varepsilon$ & $11, \varepsilon r$ & بين المجموعات \\
\hline & & & $\cdot, \sum \wedge$ & $\wedge \wedge \Lambda$ & $\leqslant r \leqslant, 90$ & المجموعات \\
\hline
\end{tabular}

مستوى (0., •) بين أفراد العينة ذوي الدخل (أكثر

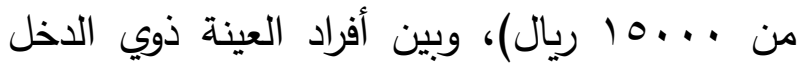

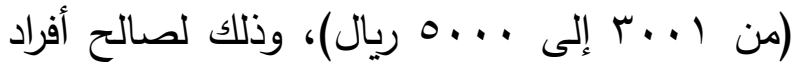

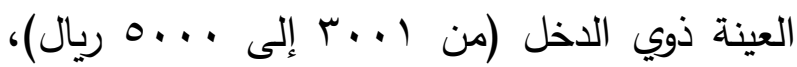

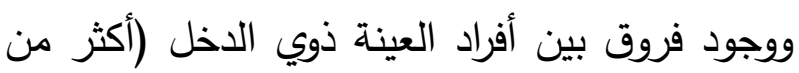

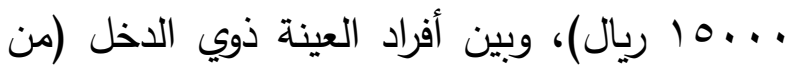

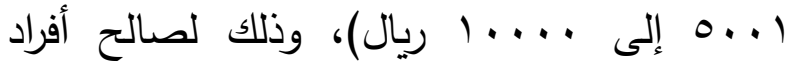

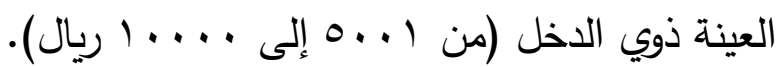

وفيما يتعلق بالدخل الثهري يشير تحليل التباين الأحادي كما يتضح من الجدول رقم (9 (19) أن قيمة

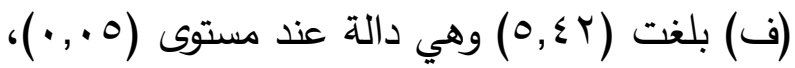

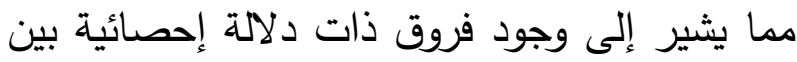

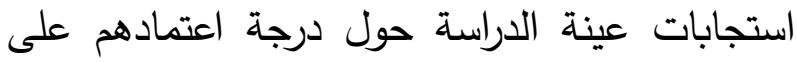

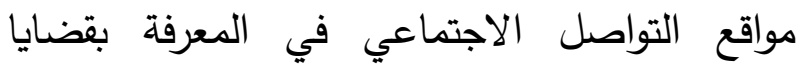
المجتمع السعودي، تعود لاختلاف الاخل الثهاعلي الثري

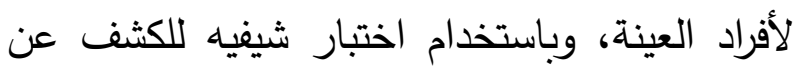

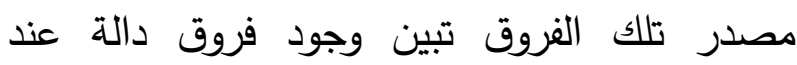
جدول رقم (9 1) اختبار تحليل التباين الأحادي لدالة الفروق في استجابات أفراد العينة حول درجة اعتمادهم

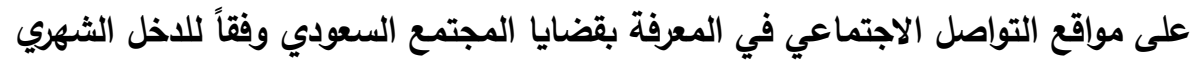

\begin{tabular}{|c|c|c|c|c|c|c|}
\hline التعليق & مستوى الدلالة & قيمة ف & متوسط المربعات & درجات الحرية & مجموع المربعات & مصدر التباين \\
\hline \multirow{2}{*}{ دالة عند مستوى } & \multirow[b]{2}{*}{$\cdot, \ldots$} & \multirow[b]{2}{*}{$0, \sum Y$} & $r, T \cdot$ & $\varepsilon$ & $1 \cdot, \varepsilon$. & بين المجموعات \\
\hline & & & $\cdot, \varepsilon \wedge$ & 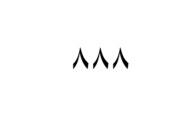 & $\leqslant r_{0}, 9 \Lambda$ & المجموعات \\
\hline
\end{tabular}

ولم تشر نتائج الدراسة إلى وجود فروق ذات دلالة مواقع التواصل الاجتماعي في المعرفة بقضايا

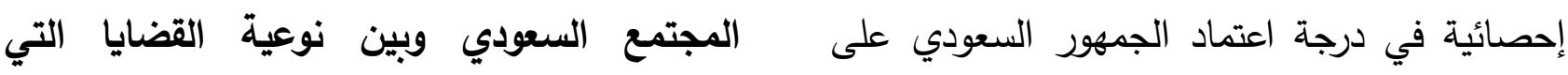
مواقع التواصل الاجتماعي في المعرفة بقضايا يحرص الجمهور السعودي على متابعتها في مواقع لوعين

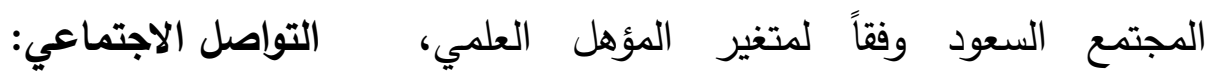

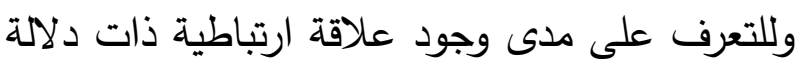
إحصائية بين درجة اعتماد الجمهور السعودي على

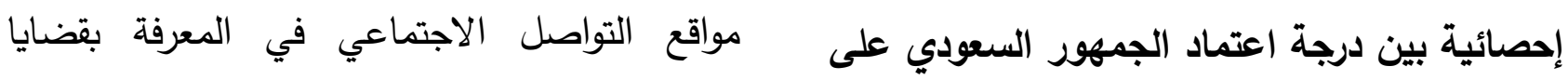

والمهنة.

الفرض الثالث: توجد علاقة ارتباطية ذات دلالة 
المجتمع السعودي وبين نوعية القضايا التي يحرص التواصل الاجتماعي في المعرفة بتلك القضايا زاد الجمهور السعودي على متابعتها في مواقع التواصل اعتمادهم على مواقع التواصل الاجتماعي لوكي الاجتماعي، يكثف معامل ارتباط (بيرسون) كما كما يتضح من الجدول رقم (ب) أن العلاقة شبه يبين الجدول رقم ( (Y) أن هنالك علاقة طردية منعدمة بين (القضايا الرياضية) وبين درجة اعتماده (موجبة) بين نوعية جميع القضايا (عدا القضايا على مواقع التواصل الاجتماعي في المعرفة بتلك لكائ الرياضية) التي يحرص الجمهور السعودي على القضايا عن المجتمع السعودي، وكانت تلك النتيجة متابعتها في مواقع التواصل الاجتماعي وبين درجة دالة إحصائياً عند مستوى (1 (.,•)، وهذا يعني أنه اعتماده على مواقع التواصل الاجتماعي في المعرفة لا توجد علاقة بين درجة اعتماد الجمهور على مواقع بتلك القضايا عن المجتمع السعودي، وكانت تلك التواصل في المعرفة بالقضايا الرياضية ودرجة العلاقات دالة إحصائياً عند مستوى (1 • . •)، ويعني اعتمادهم على مواقع التواصل الاجتماعي.

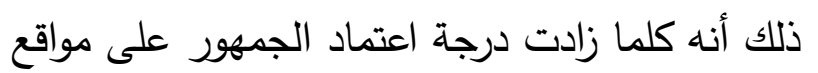
جلول رقم ( • Y) معاملات ارتباط بيرسون لقياس العلاقة بين درجة اعتماد الجمهور السعودي على مواقع التواصل الاجتماعي في المعرفة بقضايا المجتمع السعودي وبين نوعية القضايا التي يحرص الجمهور السعودي على متابعتها في مواقع التواصل

\begin{tabular}{|c|c|c|c|}
\hline وصف العلاقة & مستوى الدلالة & معامل الارتباط & القضايا \\
\hline طردية (موجبة) & دالة عند مستوى | •,. & $\cdot, r \leqslant 0$. & القضايا الاجتماعية \\
\hline طردية (موجبة) & دالة عند مستوى | .,. & $\cdot, 19 \leq 9$ & القضايا الاقتصادية \\
\hline طردية (موجبة) & دالة عند مستوى | +,. & $\cdot, 10 \leqslant \Lambda$ & القضايا السياسية \\
\hline شبه منعدمة & دالة عند مستوى | .,. &., .991 & القضايا الرياضية \\
\hline طردية (موجبة) & دالة عند مستوى | .,. & $\cdot, r \cdot \leq q$ & القضايا الثقافية \\
\hline طردية (موجبة) & دالة عند مستوى | .,. & $\cdot, Y \backslash V \cdot$ & القضايا التعليمية \\
\hline طردية (موجبة) & دالة عند مستوى | .,. & $\cdot, r \leq r r$ & القضايا الدينية \\
\hline طردية (موجبة) & دالة عند مستوى | .,. & $\cdot, r . r$ & القضايا العسكرية والأمنية \\
\hline طردية (موجبة) & دالة عند مستوى | .,. & מצrז,• & القضايا الفنية \\
\hline طردية (موجبة) & دالة عند مستوى | .,. & •, ror & القضايا العلمية والتتنية \\
\hline طردية (موجبة) & دالة عند مستوى | .,. & $\cdot, Y 001$ & القضايا الصحية \\
\hline
\end{tabular}

الفرض الرابع: توجد علاقة ارتباطية ذات دلالة المجتمع السعودي وبين دوافع متابعة الجمهور إحصائية بين درجة اعتماد الجمهور السعودي على السعودي لمواقع التواصل الاجتماعي: مواقع التواصل الاجتماعي في المعرفة بقضايا وللتعرف على مدى وجود علاقة ارتباطية ذات دلالة إحصائية بين درجة اعتماد الجمهور السعودي على 
مواقع التواصل الاجتماعي في المعرفة بقضايا اعتماد الجمهور السعودي على تلك المواقع في المجتمع السعودي وبين دوافع متابعة الجمهور المعرفة بقضايا المجتمع السعودي، اتفع دافعهم

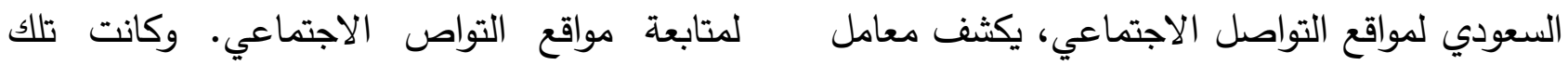

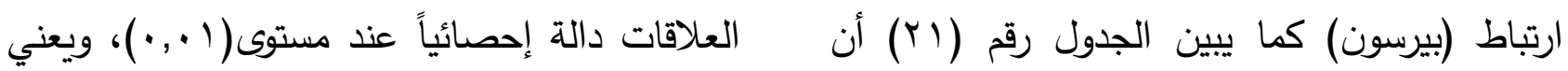
هناك علاقة طردية (موجبة) بين درجة اعتماد ذلك أنه كلما زادت درجة الاعتماد على مواقع

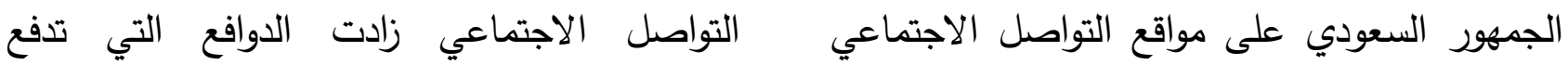
في المعرفة بقضايا المجتمع السعودي وبين دوافع الجمهور لمواقع التواصل الاجتماعي في المعرفة

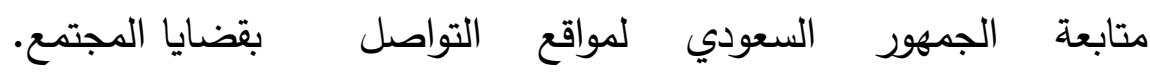
الاجتماعي، مما يشير إلى أنه كلما زادت درجة لهوبة جدول رقم (Y (Y) معاملات ارتباط بيرسون لقياس العلاقة بين درجة اعتماد الجمهور السعودي على مواقع التواصل

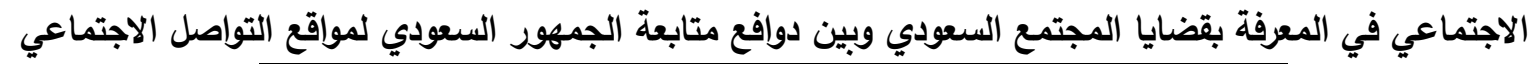

\begin{tabular}{|c|c|c|c|}
\hline وصف العلاقة & مستوى الدلالة & معامل الارتباط & المواقع \\
\hline طردية (موجبة) & دالة عند مستوى ل .,. & - E. E. YO & تويتر \\
\hline طردية (موجبة) & دالة عند مستوى ل .,. & . ITVq & الفيسبوك \\
\hline طردية (موجبة) & دالة عند مستوى ل .,. & - & ل الواتسب \\
\hline طردية (موجبة) & دالة عند مستوى ل .,. & . IATI & تيلجرام \\
\hline طردية (موجبة) & دالة عند مستوى ا .,. & 正, ז797 & اليوتيوب \\
\hline طردية (موجبة) & دالة عند مستوى 1 .,. & . IVro & المدونات \\
\hline طردية (موجبة) & دالة عند مستوى ا .,. &., 17.5 & ماي سبيس \\
\hline طردية (موجبة) & دالة عند مستوى 1 .,. & $\cdot, 1 \leqslant$. & لينكد إن \\
\hline طردية (موجبة) & دالة عند مستوى ا .,. & D, TYYO & انستجرام \\
\hline طردية (موجبة) & دالة عند مستوى | .,. & . & سناب شات \\
\hline طردية (موجبة) & دالة عند مستوى ل .,. & •, זr. & جوجل بلس \\
\hline
\end{tabular}

الفرض الخامس: توجد علاقة ارتباطية ذات دلالة يحرص الجمهور السعودي على متابعتها في مواقع

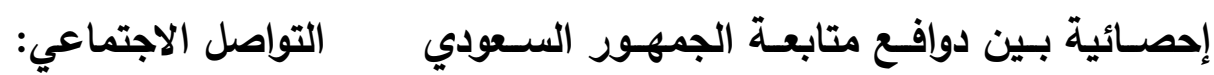
لمواقـع التواصـل الاجتمـاعي في المعرفـة بقضـايا وللتعرف على مدى وجود علاقة ارتباطية ذات دلالية إحصائية بين دوافع متابعة الجمهور السعودي لمواقع المجتمسع السـودي وبـين نوعيسة القضــايا التـي

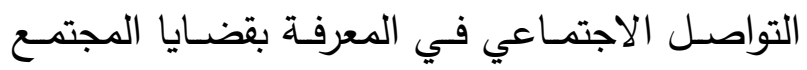


السعودي وبين نوعية القضايا التي يحرص الجمهور الســودي علـى متابعتهـــا فـي مواقــع التواصـل

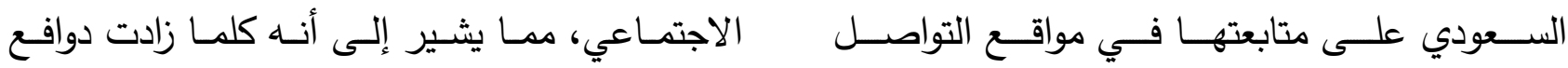

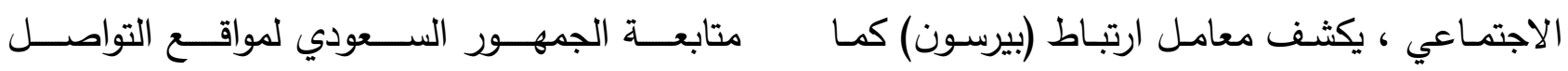

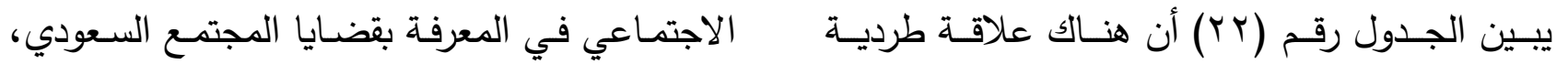

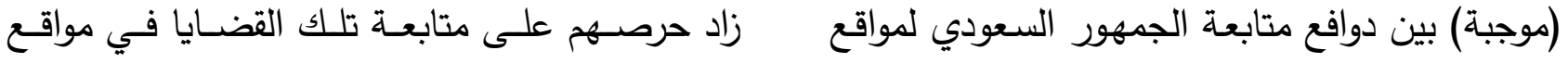

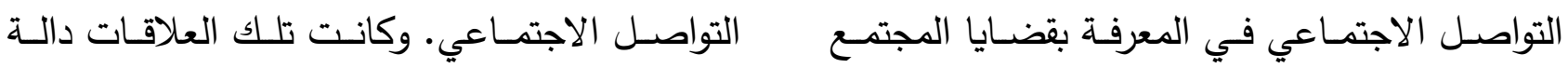

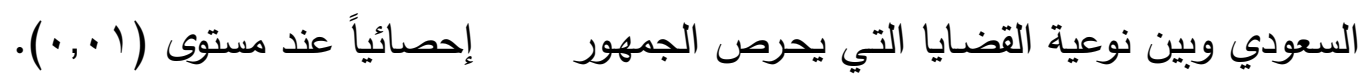
جدول رقم (r (Y) معاملات ارتباط بيرسون لقياس العلاقة بين دوافع متابعة الجمهور السعودي لمواقع التواصل الاجتماعي في

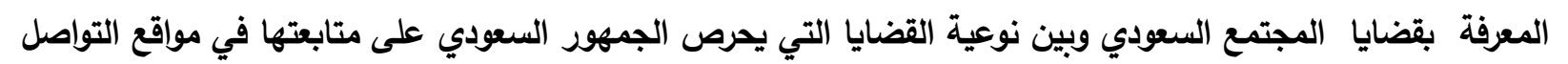
الاجتماعي

\begin{tabular}{|c|c|c|c|}
\hline وصف العلاقة & مستوى الدلالة & معامل الارتباط & القضايا \\
\hline طردية (موجبة) & دالة عند مستوى ا .,. &., $0 \vee 79$ & القضايا الاجتماعية \\
\hline طردية (موجبة) & دالة عند مستوى 1 +,. & . & القضايا الاقتصادية \\
\hline طردية (موجبة) & دالة عند مستوى ا .,. & ., $\{71$. & القضايا السياسية \\
\hline طردية (موجبة) & دالة عند مستوى ا .,. & ., Y०4) & القضايا الرياضية \\
\hline طردية (موجبة) & دالة عند مستوى ا .,. &.,$r q \leq r$ & القضايا الثقافية \\
\hline طردية (موجبة) & دالة عند مستوى ا .,. & $\cdot,\{0 \times 1$ & القضايا التعليمية \\
\hline طردية (موجبة) & دالة عند مستوى ا .,. & ., हVTr & القضايا الدينية \\
\hline طردية (موجبة) & دالة عند مستوى ا .,. & $\cdot, \leq \leqslant r_{0}$ & الألضـــــايا العــــكرية \\
\hline طردية (موجبة) & دالة عند مستوى ا .,. &., . 977 & القضايا الفنية \\
\hline طردية (موجبة) & دالة عند مستوى ا .,. & $\cdot, \leqslant \leq 90$ & القضايا العلمية والتقنية \\
\hline طردية (موجبة) & دالة عند مستوى 1 .,. & $\cdot, \leqslant 90 \mathrm{~V}$ & القضايا الصحية \\
\hline
\end{tabular}

الفرض السادس: توجد علاقة ارتباطية ذات دلالة وللتعرف على مدى وجود علاقة ارتباطية ذات دلالة

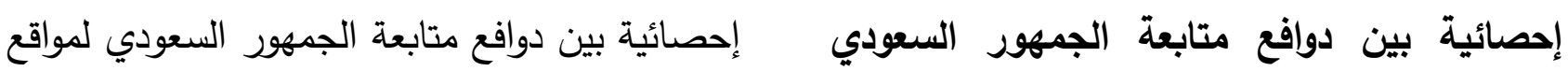

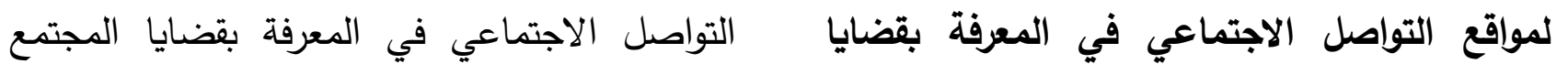
المجتمع السعودي وبين مدى متابعتهم لتلك المواقع السعودي وبين مدى متابعتهم لتلك المواقع في

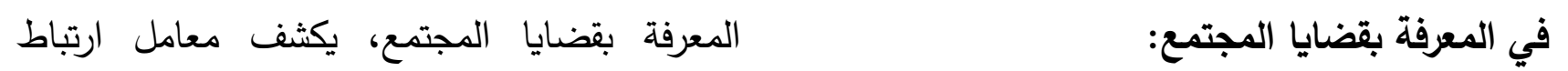


كما يتضح من الجدول رقم (Yr) أن هناك علاقة طردية (موجبة) بين الدرجة الكلية لدوافع متابعة لهدول الجمهور السعودي لمواقع التواصل الاجتماعي في لـاني المعرفة بقضايا المجتمع السعودي، وبين مدى مئى متابعتهم لتلك المواقع في المعرفة بقضايا المجتمع السعودي، مما يشير إلى أنه كلما زادت دوافع متابعة الجمهور السعودي لمواقع التواصل الاجتماعي في لي لئي المعرفة بقضايا المتمع السعودي، زاد مدى متابعتهر لتلك المواقع في المعرفة بقضايا المجتمع السعودي.

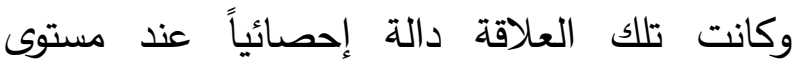

$$
\cdot(\cdot, \cdot 1)
$$

(بيرسون) كما يبين الجدول رقم (TM) أن هناك علاقة طردية (موجبة) بين دوافع متابعة الجمهور السعودي لمواقع التواصل الاجتماعي في المعرفة بقضايا المجتمع السعودي: (دوافع معرفية، دوافع توجيهية، دوافع سلوكية)، وبين مدى متابعتهم لتلك دلك

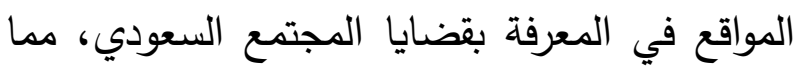
يشير إلى أنه كلما زادت دوافع متابعة الجمهور السعودي لمواقع التواصل الاجتماعي في المعرفة بقضايا المجتمع السعودي، زاد مدى متابعتهم لتلك المواقع في المعرفة بقضايا المجتمع السعودي.

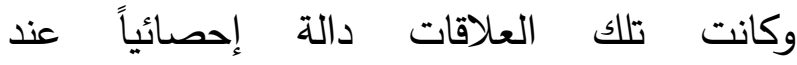
مستوى( ( •, •).

جدول رقم (rr) معاملات ارتباط بيرسون لقياس العلاقة بين دوافع متابعة الجمهور السعودي لمواقع التواصل الاجتماعي

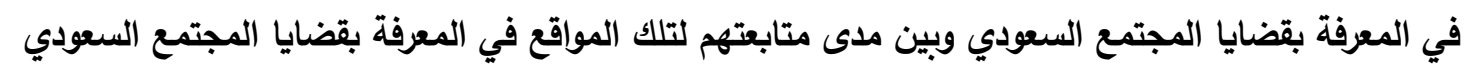

\begin{tabular}{|c|c|c|c|}
\hline وصف العلاقة & مستوى الدلالة & معامل الارتباط & الدوافع \\
\hline طردية (موجبة) & دالة عند مستوى 1 .,. & $\cdot, 01 \wedge V$ & دوافع معرفية \\
\hline طردية (موجبة) & دالة عذد مستوى 1 .,. & $\cdot, \sum \vee 19$ & دوافع توجيهية \\
\hline طردية (موجبة) & دالة عذد مستوى ل .,. & • & دوافع سلوكية \\
\hline طردية (موجبة) & دالة عند مستوى ل .,. &., 011. & الدرجة الكلية للدوافع \\
\hline
\end{tabular}

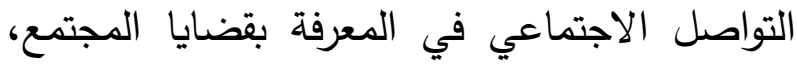
مناقشة النتائجج:

وقد تمت الدراسة بالتطبيق على الجمهور في مدينة الرياض، وإنتهت الدراسة إلى النتائج التالية: ا-وجود اعتماد كبير على مواقع التواصل الاجتماعي في المعرفة بقضايا المجتمع: كثفت نتائج الدراسة عن وجود اعتماد كبير من قبل أفراد العينة على مواقع التواصل الاجتماعي في معرفتهم بقضايا المجتمع السعودي المختلفة، إذ فقط
سعت هذه الدراسة إلى التعرف على الدوافع والأهداف التي تدفع الجمهور السعودي للاعتماد على مواقع التواصل الاجتماعي في المعرفة بقضايا المجتمع السعودي، وما هي المواقع التي يعتمد عليها الجمهور في الحصول على المعلومات حول قضايا المجتمع السعودي، ودرجة اعتماد الجمهور على هذه المواقع، والأسباب التي تدفعهم للاعتماد على مواقع 
التواصل الاجتماعي على نشر أي تقسير لأي قضية

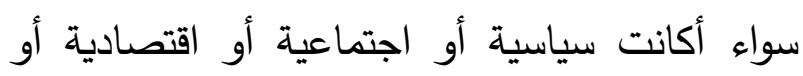
ثقافية أو غيرها دون الاضطرار للتعامل مع حراس الس الهيه البوابة في الإعلام التقليدي، ومما يؤكد ذلك ما بينه الدراسة الميدانية من أن أحد أهم أسباب استخدام المبحوثين لمواقع التواصل الاجتماعي السرعة في

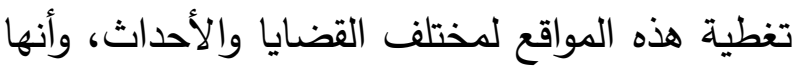
أصبحت أحد أشكال الإعلام البديل في ظل تراجع

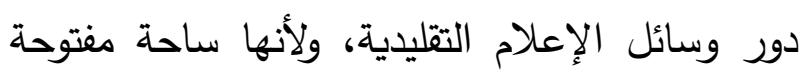

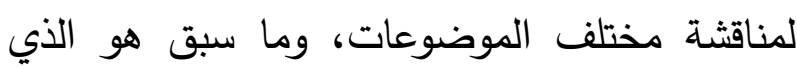
أدى إلى حد كبير لاعتماد أفراد العينة على مواقع التواصل الاجتماعي في المعرفة بقضايا المجتمع.

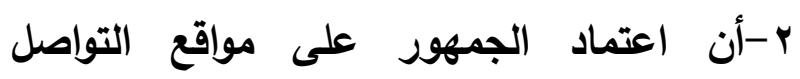
الاجتماعي في المعرفة بقضايا المجتمع السعودي تركز في الارجة الأولى على الدوافع النفعية

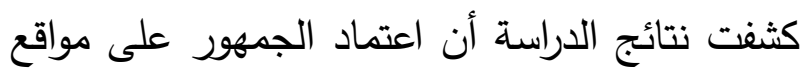
التواصل الاجتماعي في المعرفة بقضايا المجتمع السعودي تركز في الدرجة الأولى على الدوافع

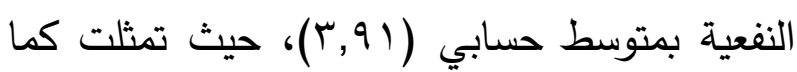
جاء في الدراسة الميدانية في البحث عن المعلومات

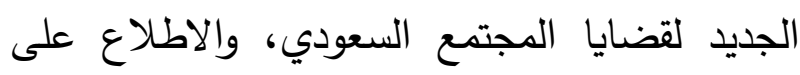
هذه القضايا، والاسترشاد بما في مواقع التواصل الاجتماعي من آراء حول قضايا المجتمع السعودي، لهاهئ وإدراك الحقائق حول هذه القضايا، وما جاء في الاء الدراسة الحالية يتفق مع دراسة كل من: الكافي

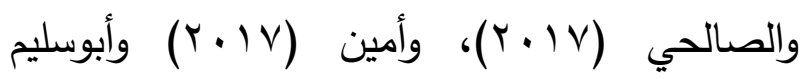

(T/\%) من أفراد العينة لا يعتمدون على مواقع التواصل الاجتماعي، وهذه النتيجة تتفق مع دراسة لهن

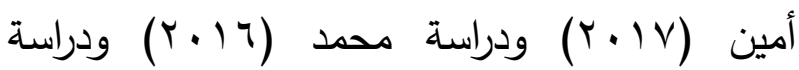

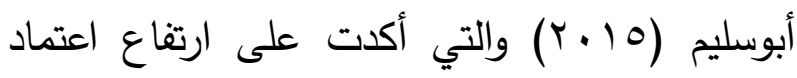

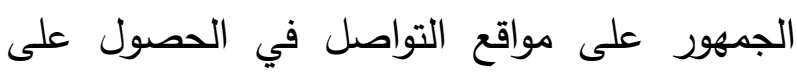

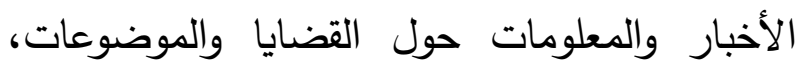
ويرى الباحث أن هذا أمر طبيعي في هذا العصر

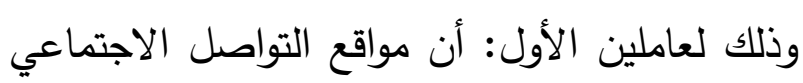
استطاعت أن تفرض وجودها على الاولى الجمهور السعودي بمختلف فئاته، فهذا العصر يشهر نزوحاً

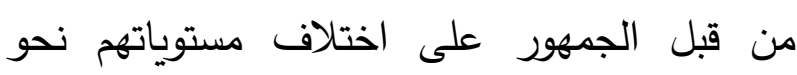
استخدام هذه المواقع، فعدد المستخدمين السعوديين

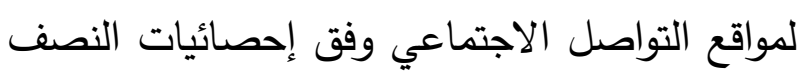

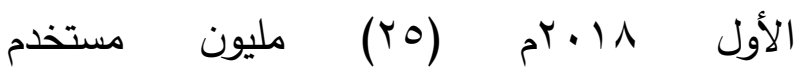
‘(https://www.globalmediainsight.com, n.d.) أما العامل الثاني فهو احتلال مواقع التواصل

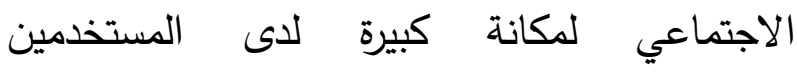
السعوديين، لما تتمتع به هذه المواقع كما جاء في لإهي الإطار النظري من ميزات مقارنة بالوسائل التقليدية

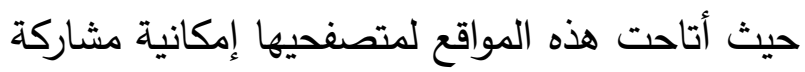
الملفات والصور وتبادل مقاطع الفيديو، كما مكنت مستخدميها من إنشاء المدونات الإلكترونية وإجراء

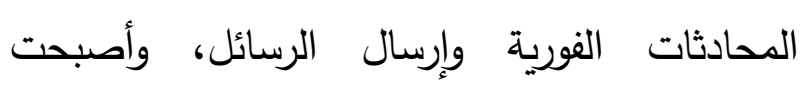
الوسيلة الأساسية لاى السعوديين لتبادل المعلومات

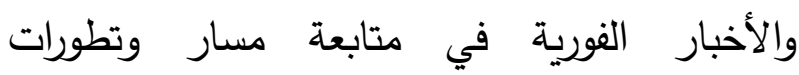
الأحداث، بالإضافة إلى ذلك قدرة مستخدمي مواقع 
ذكرنا أنفاً الكثير من الغموض الذي يكتف بعض

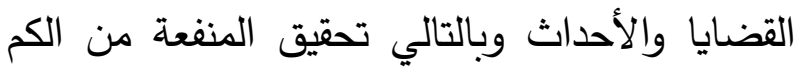
الهائل من المعلومات حول الكثير من القضايا والأحداث.

ץ- اعتماد الجمهور على تويتر بارجة كبيرة جداً في المعرفة بقضايا المجتمع السعودي: بينت نتائج الدراسة فيما يتعلق بمواقع التواصل الاجتماعي التي يعتمد عليها الجمهور في المعرفة

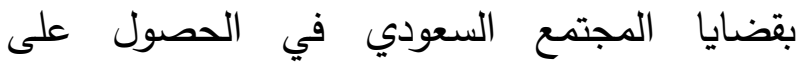
المعلومات عن قضايا المجتمع السعودي أن افراد العينة يعتمدون على تويتر بدرجة كبيرة جداً بمتوسط

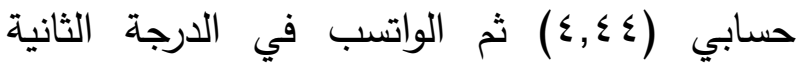
بمتوسط حسابي (†,0.0)، كما بينت نتائج الدراسة عدم اعتماد أفراد العينة على الفيسبوك وتيلجرام والمدونات في المعرفة بقضايا المجتمع، وهذه النتيجة

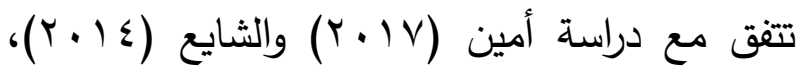
في مجيء تويتر في المرتبة الأولى في اعتماد الجمهور في الحصول على المعلومات حول القضايا المحتلفة، ولا تتفق مع دراسة الكافي والصالحي (Y.MV)

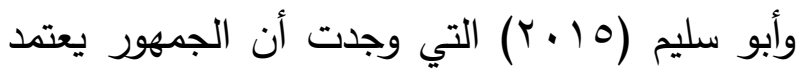
على الفيسبوك بالدرجة الأولى في الحصول على المعلومات، وهذا من وجهة نظر الباحث طبيعي كون هذه الدراسات مطبقة على جمهور عربي إذ إن أغلب الجمهور في الدول العربية كما تؤكد العديد من هن الدراسات يستخدمون الفيسبوك، ويرى الباحث أن

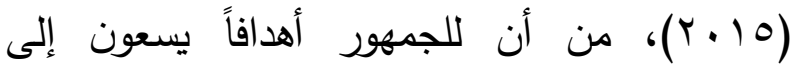

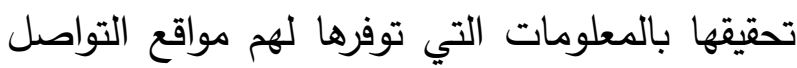
الاجتماعي، وهذه النتيجة تؤكد ما جاء في الإطار النظري من أن الجمهور يسعى من خلال الاعتماد على وسائل الإعلام إلى فهم البيئة المحيطة به وما يحدث فيها، وأفضل من يقدم ذلك هي وسائل الإعلام، إذ إن هذه الوسائل وفق نظرية الاعتماد تعتبر نظام معلومات يتحكم في مصادر تحقق

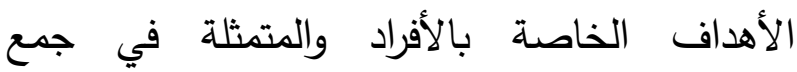

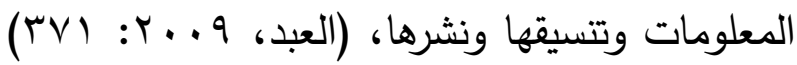
بالإضافة إلى ذلك فإن الجمهور يحرص على استقاء مزيد من المعلومات من وسائل الإعلام لفهم الواقع الاجتماعي من حولهم والانتفاع بهذه المعلومات،

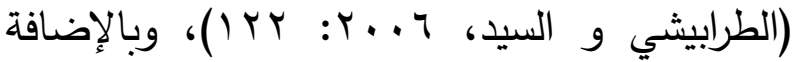
إلى ذلك فإن هذه النتيجة تتفق أيضاً مع ما جاء في الإطار النظري من أن الجمهور يسعى من خلال

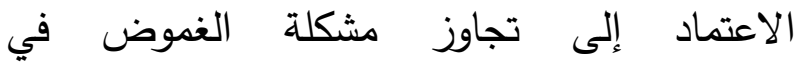
الموضوعات والناتجة عن نقص أو عدم كفاية

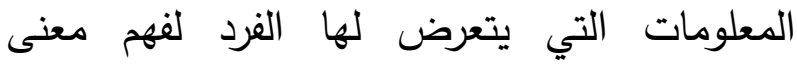
الأحداث أو تحديد التفسيرات الصحيحة لها، وهو ما لأنيان يتفق مع فروض نظرية الاعتماد من أن الأفراد

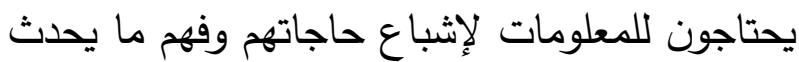
من حولهم، ويرى الباحث أن نظام المعلومات الذي لإن تتميز به الإنترنت بشكل عام ومواقع التواصل خاصة قد مكنت المستخدمين من الوصول إلى هذه المعلومات بكل يسر وسهولة واستخدامها وإزالة كما 
ففي الظروف الطارئة والأحداث التي تقع في السعودية استطاع تويتر بشكل خاص من التفاعل مع هذه الأحداث على مدار الساعة ونقل الحدث أولاً بأول ومن مكان حدوثه ويواكب هذا النقل سرعة انتشار مذهلة لا يستطيع الإعلام التقليدي مجاراتها بأي حال من الأحوال وتحت أي ظرف من الظروف، وقد اثبتت ذلك التجارب الخاصة بقضايا حدثت في السعودية فقد بات تويتر الآن يعبر عما بداخل السعوديين بطرح العديد من القضايا من خلاله، فعلى سبيل المثال طرح المغردون قضية انتشار الجرب في عدد من مناطق المملكة، وقضية الإسكان، وقضايا اجتماعية متعددة، وقضايا اقتصادية وسياسية، ما كان لها أن تطرح في الإعلام التقليدي، ولذلك ليس غربياً أن يتم استخدام تويتر من قبل قادة دول العالم وعلى رأسهر الرئيس الأمريكي دونالد ترامب، ومسؤولين وغيرهم بهدف إيصال رسائل معينة بشكل سريع حيث أدركوا أنه وسيلة سريعة في إيصال ما يريدون. ع -اعتماد الجمهور على المواقع الإخبارية بشكل كبير، وعلى مواقع الجهات الحكومية بثكل متوسط، وبشكل ضعيف على مواقع الصحف الورقية في المعرفة بقضايا المجتمع السعودي: أظهرت نتائج الدراسة اعتماد الجمهور على المواقع الإخبارية بشكل كبير بمتوسط حسابي ( (T),r)، وعلى مواقع الجهات الحكومية بشكل متوسط ريط بمتوسط حسابي (؟؟,ץ) وهذا يتفق مع دراسة أمين
ارتفاع استخدام أفراد العينة لتويتر يعود إلى أن تويتر هو الموقع الاجتماعي المفضل لاى السعوديين حيث يصل عدد مستخدمي تويتر في السعودية خلال

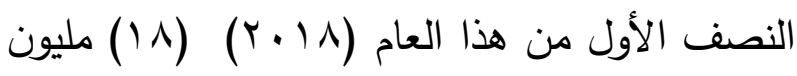
نشط،

مستخدم

(https://www.globalmediainsight.com, n.d.) ومما يعزز هذه النتيجة أن السبب الأول في اعتماد أفراد العينة على مواقع التواصل الاجتماعي في المعرفة بقضايا المجتمع السعودي كما جاء في الدراسة الميدانية كان السرعة في تغطية القضايا والأحداث، وهذا ما توفرة مواقع التواصل وبالذات تويتر ولذلك نجد أن التلفزيون السعودي والصحف السعودية اليومية، وحتى مواقعها الإخبارية كما بينت نتائج الدراسة جات بدرجة متوسطة في الاعتماد، ويرى الباحث أن تويتر استطاع أن يفرض نفسه على المستخدمين السعوديين لعدة أسباب من أهمها أن تويتر أصبح بالنسبة للمستخدمين لسعوديين المتنفس كي يعبروا عن اهتماماتهم وهموهم المتتوعة، بالإضافة إلى ذلك سهولة الاستخدام حيث وفر ذلك استخدام الهواتف الذكية، إذ إن هذا الاستخدام يجعل التعرض للأخبار والقضايا المتعددة مستمراً طوال الوقت بخلاف الوسائل التقليديسة التي يتعرض الجمهور لموادها بأوقات محددة، كما أن تويتر في المملكة العربية السعودية استطاع يخلق إعلاماً مختلفاً عن الإعلام التقليدي في الطرح والتفاعل وسرعة نقل الخبر وتدعيمه بالصورة الحية والمعبرة، 
التواصل الاجتماعي في متابعة القضايا الاجتماعية

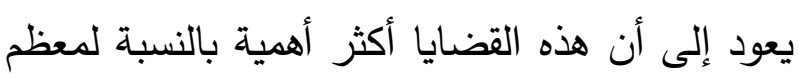

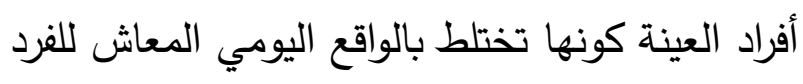

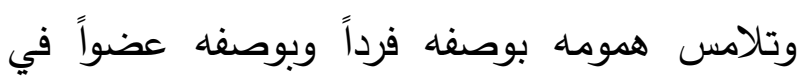
أسرة أيا كان موقعه داخلها، كما أن توالي القضايا

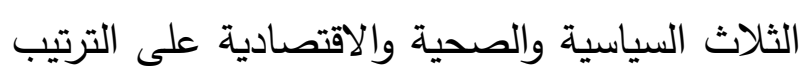
بعد القضايا الاجتماعية يشير إلى أن هذه القضايا

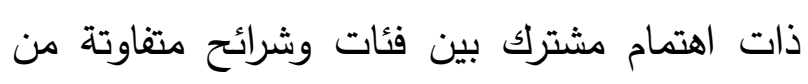
الجمهور دون استثناء فحجم القضايا والمشكلات الاجتماعية والاقتصادية والصحية في مجتمعنا الذي

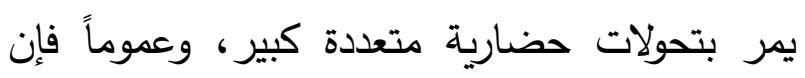

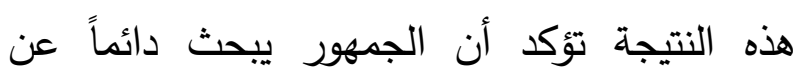

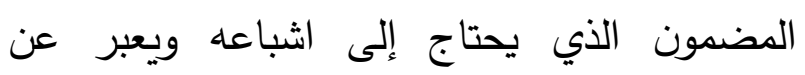
احتياجاته واهتماماته، وهذا يتفق أيضاً مع ما أكده

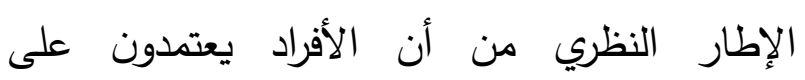

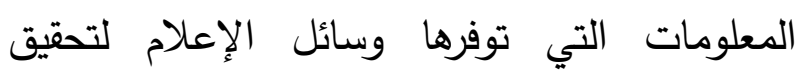

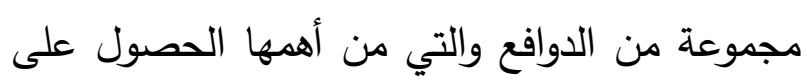

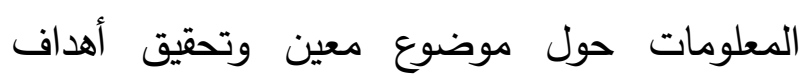

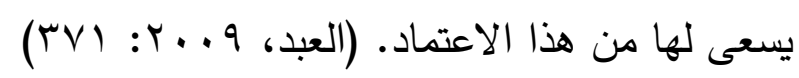
ه-السرعة في تغطية مواقع التواصل الاجتماعي للقضايا والأحداث، وتراجع دور وسائل الإعلام

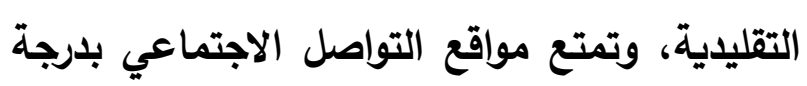
كبيرة من الحرية، وقدرة المستخدمين لمناقشة كافة

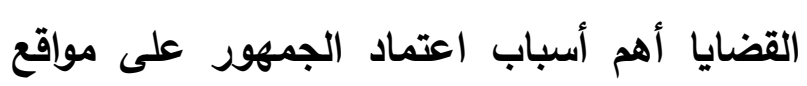
التواصل الاجتماعي:

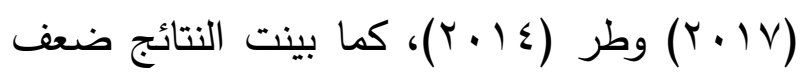
اعتماد أفراد العينة على مواقع الصحف الورقية

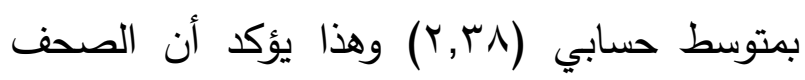

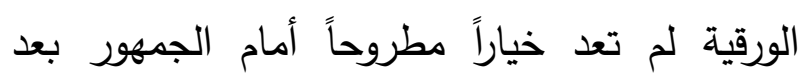

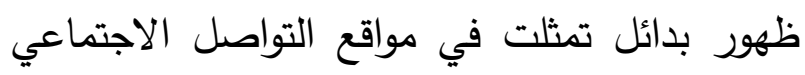
حيث قامت بكسر احتكار الصحف الورقية والقنوات التلفزيونية الكبرى للمعلومات بعد أن كانت تلك الك القنوات والصحف تسهم في تكوين الرأي العام باعتبار أنها أول وأهم مصدر إخباري بالنسبة للجمهور - لبعن القيا ه- تركز الاعتماد على مواقع التواصل الاجتماعي في متابعة قضايا المجتمع السعودي على القضايا الاجتماعية: كثفت نتائج الدراسة أن أبرز القضايا التي يحرص

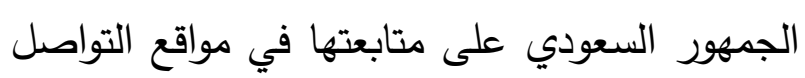
الاجتماعي هي القضايا الاجتماعية بمتوسط حسابي

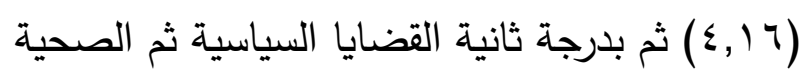
وبعدها بالدرجة الرابعة القضايا الاقتصادية، وهذه بانية

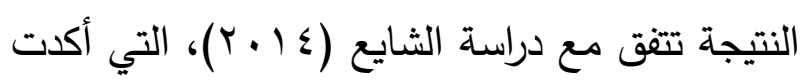

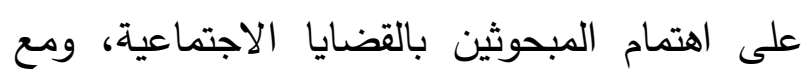

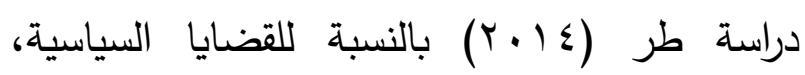

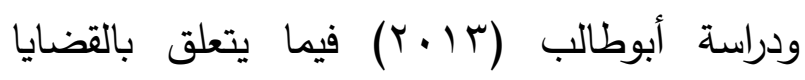
الصحية، كما أن هذه الدراسة لا تتفق مع دراسة منية

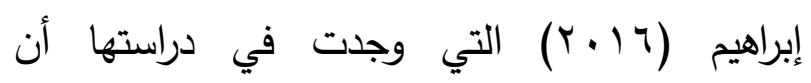
المبحوثين يهتمون بالمضامين الرياضية والفنية،

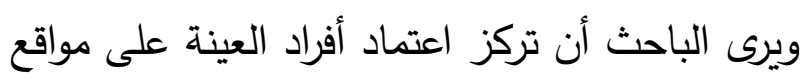


بالهم مع عدد غير محدود من المستخدمين الآخرين في أنحاء متقرقة من العالم بدون قيود وبحرية كاملة. وفيما يتعلق بنتائج اختبار الفروض تؤكد الدراسة على الآتي: ا-بينت نتائج اختبار فروض الدراسة وجود فروق ذات دلالة إحصائية في دوافع متابعة الجمهور السعودي لمواقع التواصل الاجتماعي في المعرفة بقضايا المجتمع السعودي وفقاً للحالة الاجتماعية، والسن، والدخل الشهري، والمؤهل العلمي، والمهنة. r-بينت نتائج اختبار فروض الدراسة وجود علاقة

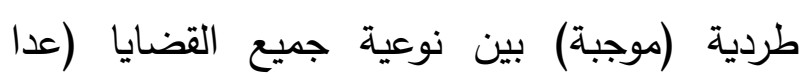
القضايا الرياضية) التي يحرص الجمهور السعودي على متابعتها في مواقع التواصل الاجتماعي وبين درجة اعتماده على مواقع التواصل الاجتماعي في المعرفة بتلك القضايا عن المجتمع السعودي، ووجود علاقة شبه منعدمة بين (القضايا الرياضية) وبين درجة اعتماده على مواقع التواصل الاجتماعي في المعرفة بتلك القضايا عن المجتمع السعودي. ب-بينت نتائج اختبار فروض الدراسة وجود علاقة طردية (موجبة) بين درجة اعتماد الجمهور السعودي على مواقع التواصل الاجتماعي في المعرفة بقضايا المجتمع السعودي وبين دوافع متابعة الجمهور السعودي لمواقع التواصل الاجتماعي ع-بينت نتائج اختبار فروض الدراسة وجود علاقة طردية (موجبة) بين دوافع متابعة الجمهور السعودي لمواقع التواصل الاجتماعي في المعرفة بقضايا
بينت نتائج الدراسة أن من أسباب اعتماد أفراد العينة على مواقع التواصل الاجتماعي في المعرفة بقضايا المجتمع تركزت في عدة أسباب منها: السرعة في تغطية مواقع التواصل الاجتماعي للقضايا والأحداث، وتراجع دور وسائل الإعلام التقليدية لأن مواقع لإن التواصل الاجتماعي أصبحت أحد أشكال الإعلام البديل، وتمتع مواقع التواصل الاجتماعي بدرجة كبيرة من الحرية، وقدرة مستخدمي مواقع التواصل على مناقشة كافة القضايا، وهذا يتفق مع دراسة الكافي والصالحي (Y.IV)

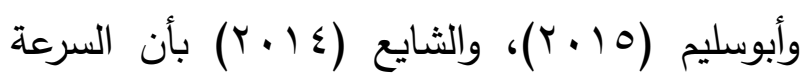
في نقل الأحداث من أهم أسباب متابعة واستخدام مواقع التواصل الاجتماعي، ويرى الباحث أن هذه الأسباب هي التي جعلت أفراد العينة يعتمدون على مواقع التواصل الاجتماعي في المعرفة بقضايا المجتمع السعودي، فهذه المواقع تتميز بالتفاعلية إذ خلقت نوعاً من التفاعل بين السعوديين أنفسهم والعالم بعد العزلة التي كانت تفرضها عليه ظروف الحياة، كما أدت مواقع التواصل الاجتماعي مثل فيسبوك وتويتر وانتشار أجهزة الهواتف الذكية وتطورها والقدرة على الارتباط بالإنترنت من أي مكان إلى رفع سقف حرية التعبير والحصول على المعلومة والقدرة على الاتصال بشكل غير مسبوق وقد مكن الإعلام الجديد الأمر الذي مكن المستخدمين من مناقشة أي موضوع يخطر على لإعلى 
تداول معلومات من مواقع قد لا تتسم بالمصداقية أو غير دقيقة. r-انطلاقاً مما أظهرته نتائج الدراسة من ضعف في

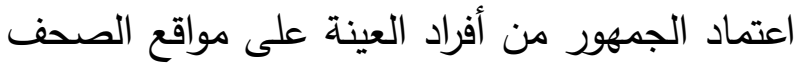

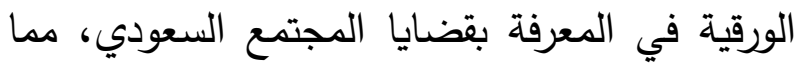
يؤكد على تراجع الإعلام المهني أمام إعلام الهواية

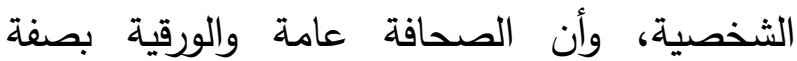
خاصة في مأزق وهذا المأزق لن يحل إلى من خلال اهتمام الصحف الورقية بتطوير أدواتها المهنية، والتحول التدريجي نحو الإعلام الرقمي لكي يكون لها حضور في المشهد الإعلامي الحالي.

يوصي الباحث بالاهتمام بعدد من الموضوعات البحثية التي تثيرها نتائج هذه الدراسة من مثل: ا-دراسة المضامين المقدمة عبر مواقع التواصل مليه الاجتماعي. r-دراسة مستقبل الصحافة الورقية والتحديات التي تواجهها. ع-دراسات عن مواقع التواصل الاجتماعي والبناء الاجتماعي والثقافي والسياسي. ه-دراسات عن تأثيرات الإعلام الجديد على ولى

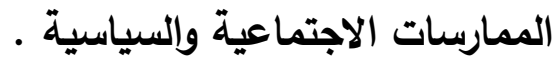

\section{المراجـع}

بسمة قائد البناء. (ع ا ـ ؟). تويتر والبناء الاجتماعي والثقافي لدى الثباب .طا. . بيروت: المؤسسة

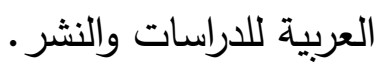

المجتمع السعودي وبين نوعية القضايا التي يحرص الجمهور السعودي على متابعتها في مواقع التواصل

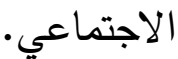
0-بينت نتائج اختبار فروض الدراسة وجود علاقة طردية (موجبة) بين دوافع متابعة الجمهور السعودي لمواقع التواصل الاجتماعي في المعرفة بقضايا المجتمع السعودي: (دوافع معرفية، دوافع توجيهية، دوافع سلوكية)، وبين مدى متابعتهم لتلك المواقع في المعرفة بقضايا المجتمع السعودي، ووجود علاقة

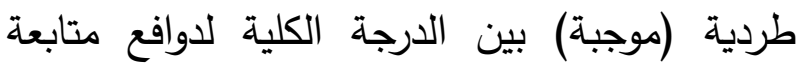
الجمهور السعودي لمواقع التواصل الاجتماعي في

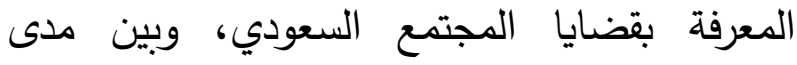
متابعتهم لتلك المواقع في المعرفة بقضايا المجتمع

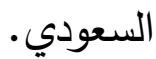

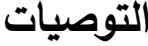

بالرغم من أن الباحث يرى أن كل نتيجة تم التوصل

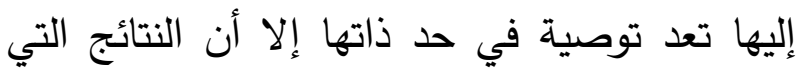
توصلت إليها الدراسة تثير العديد من التوصيات

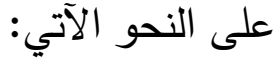
ا-في ضوء ما كثفت عنه نتائج الدراسة من ارتفاع

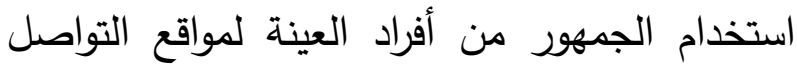
الاجتماعي في المعرفة بقضايا المجتمع فإن الباحث يدعو الجهات الحكومية وبالذات الخدمية إلى تكثيف نشاطها في مواقع التواصل وإمداد الجمهور بالمعلومات التي تزيل الغموض عن الكثير من

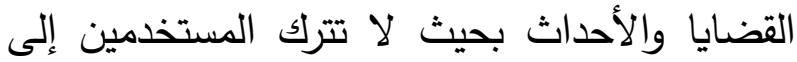


الاجتماعي للحصول على الأخبار والمعلومات، دراسة مسحية تحليلية -رسالة ماجستير غر الاجلماري منشورة. عمان: كلية الاعلام، جامعة الثرق ماته الأوسط.

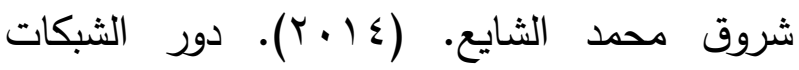
الاجتماعية في تتمية مشاركة الثباب السعودي في القضايا المجتمعية: دراسة مسحية على شبكة لهية تويتر -بحث مكمل للماجستير. قسم الإعلامكلية الآداب- جامعة الملك سعود. صابر حسن محمد طر. (عابـ (ب). العلاقة بين الاعتماد على المواقع الإخبارية الإليكترونية

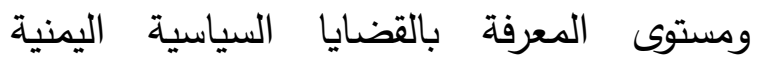

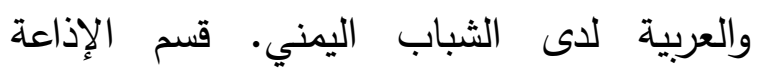
والتلفزيون:كاية الإعلام، جامعة القاهرة.

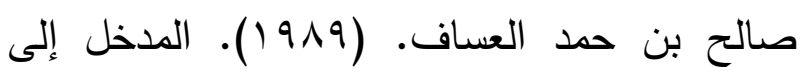

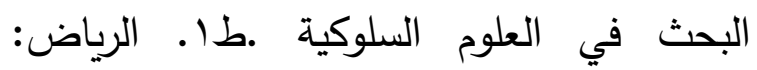
العبيكان. - البحب

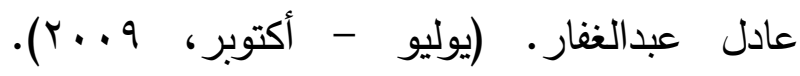
العلاقتبين متابعة الثباب الجامعي لتطورات

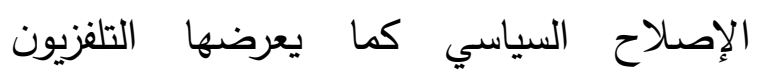
واتجاهاتهم نحو مستقبل العمل السياسي في مصر. المجلة المصرية لبحوث الإعلام، (عَ) .$\leqslant \leqslant-1$

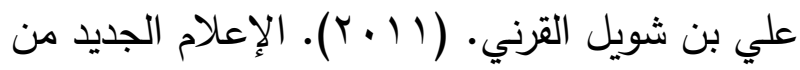
الصحافة التقليدية إلى الإعلام الاجتماعي لتصي وصحافة المواطن. الرياض: د. ن.
حسن عماد مكاوي، و ليلى حسين السيد. (911 (1). الاتصال ونظرياته المعاصرة. طاء ـ القاهرة: الدار المصرية اللبنانية.

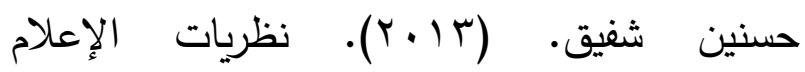
وتطبيقاتها في دراسات الإعلام الجديد ومواقع التواصل الاجتماعي. القاهرة: دار فكر وفن

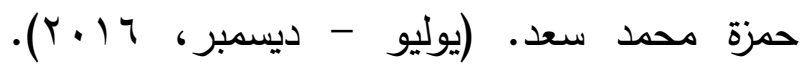
اعتماد الجالية المصرية بالإمارات على وسائل الإعلام التقليدية والحديثة كمصدر للمعلومات عن قضية جزيرتي تيران وصنافير. المجلة العربية

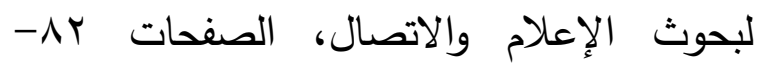
.1 .9 دانييل جوني. (10 • ب). أساسيات اختيار العينة في

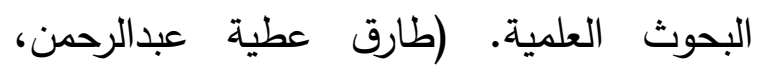
ترجمة) الرياض: معهد الإدارة العامة.

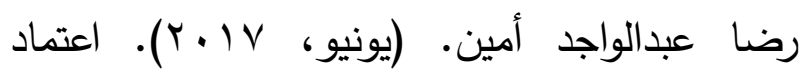
الجمهور على الإعلام الجديد كمصدر للمعلومات عن قضايا التتمية المستدامة: دراسة ميدانية على العى لعائ

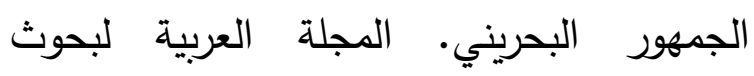

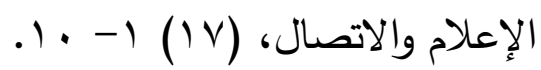

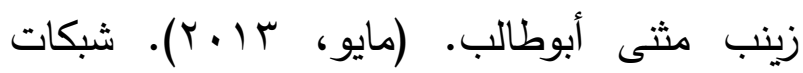
التواصل الاجتماعي كمصدر للمعلومات الصحية لاى الجمهور السعودي. المجلة العربية للإعلام والاتصال، صفحة 09. شرحبيل غالب حميد أبو سليم. (10 ب ؟). اعتماد طلبة الجامعات الأردنية على شبكات التواصل 
مرفت الطرابيشي، و عبدالعزيز السيد. ( ( . †).

نظريات الاتصال. القاهرة: دار النهظة العربية.

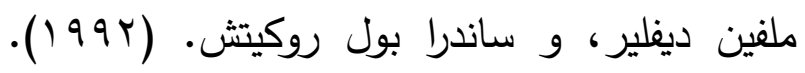

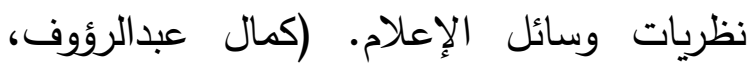

المترجمون) القاهرة: الدار الدولية للنشر والتوزيع.

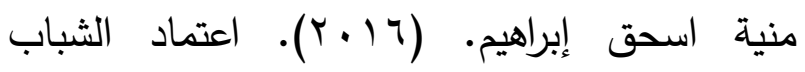

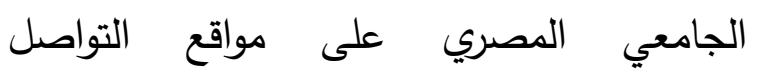

الاجتماعي كمصدر للأخبار دراسة تطبيقية على

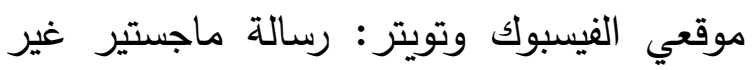
منشورة. كلية الإعلام - جامعة القاهرة.

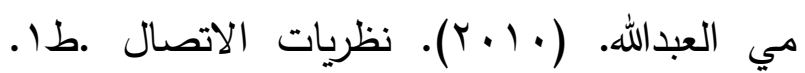

$$
\text { بيروت: دار النهضة العربية. }
$$

نهى عاطف العبد. (يناير كيونيه، 9. . . ب). اعتماد

الجمهور العربي على القنوات الفضائية الأجنبية

الموجهة باللغة العربية في أوقات الأزمات

بالتطبيق على أزمة العدوان الإسرائيلي على غزة.

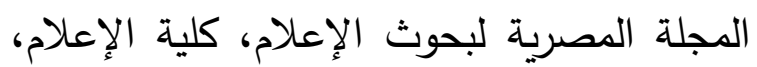

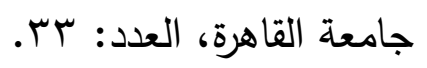

Amer Aldahmashi F, Reliance of the Saudi Youth on Social Media as a Source of Information about Al-Hazem Storm, J Mass Communicat Journalism 2017, 7:5.

Ball, J. S., \& Defleur, M. L. (1992). Thories of Mass Communication (Vol. 4). New York: Longman.

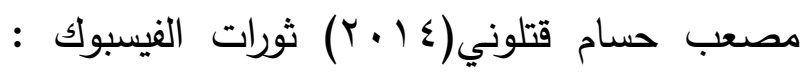
مستقبل وسئل التواصل الاجتماعي في التغيير طا ـبيروت :شركة المطبوعات للنشر والتوزيع.

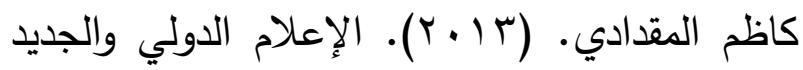
وتصدع السلطة الرابعة .طا ـ ـعمان: دار أسامة للنشر والتوزيع.

محمد عبدالحميد. (10 (ب). نظريات الإعلام واتجاهات التأثير .طع. القاهرة: عالم الكتب.

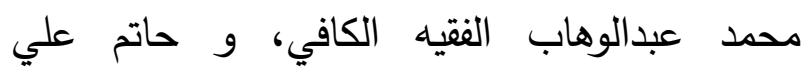

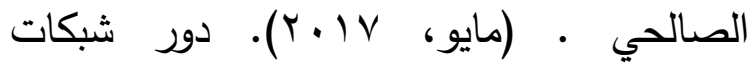

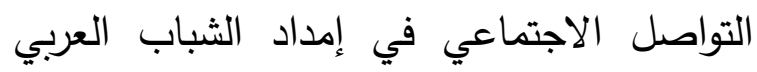
بالمعلومات والأخبار حول ظاهرة الإرهاب: دراسة مقارنة بين الشباب في أربع دول عربية. المجلة

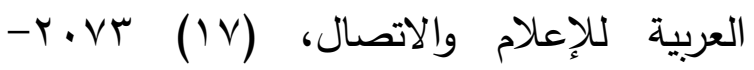
.r. محمود علم الدين. (ع ( • ب). الإعلام الرقمي الجديد

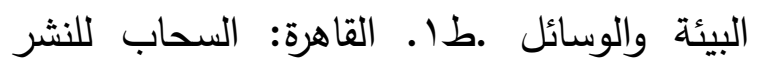
والتوزيع.

https://wearesocial.com . https://www.globalmediainsight.com. (n.d.). https://www.globalmediainsight.com . https://www.stats.gov.sa/ar . 


\title{
The extent to which the Saudi public relies on social networking sites to obtain information on the issues of the Saudi society: A survey study in the city of Riyadh
}

\author{
Dr. Abdulmalik Abdulaziz Shalhoob \\ Associate Professor Media Department \\ King Saud University Riyadh, Saudi Arabia
}

\begin{abstract}
Summary. this study aims to identify the motives and objectives that drive the Saudi public to rely on the social networking sites to obtain information on the issues of the Saudi society. The study also aims to identify which of these social networking sites the public depends on and the reasons that drive the Saudi public reliance on the social networking sites to obtain information on the issues of the Saudi society. This study also aims to find whether there are statistically significant differences in the motivation of the Saudi public to follow the social networking sites to obtain information on the issues of the Saudi society according to their demographic characteristics, and the extent of a significant statistical correlation between the degree of the Saudi public's reliance on social networking sites to obtain information on the issues of the Saudi society and the use of the social networking sites for networking. Survey and questionnaire method were used to obtain information with a sample size of (893) Saudi Riyadh-resident individuals. The results of the study showed the reliance of the sample size individuals on the social networking sites to obtain information on the issues of the Saudi society as the primary reason for the use of these social networking sites. The results also showed the public's reliance on Twitter to a great extent in obtaining information about the issues of Saudi society.
\end{abstract}

